Historic, Archive Document

Do not assume content reflects current scientific knowledge, policies, or practices. 


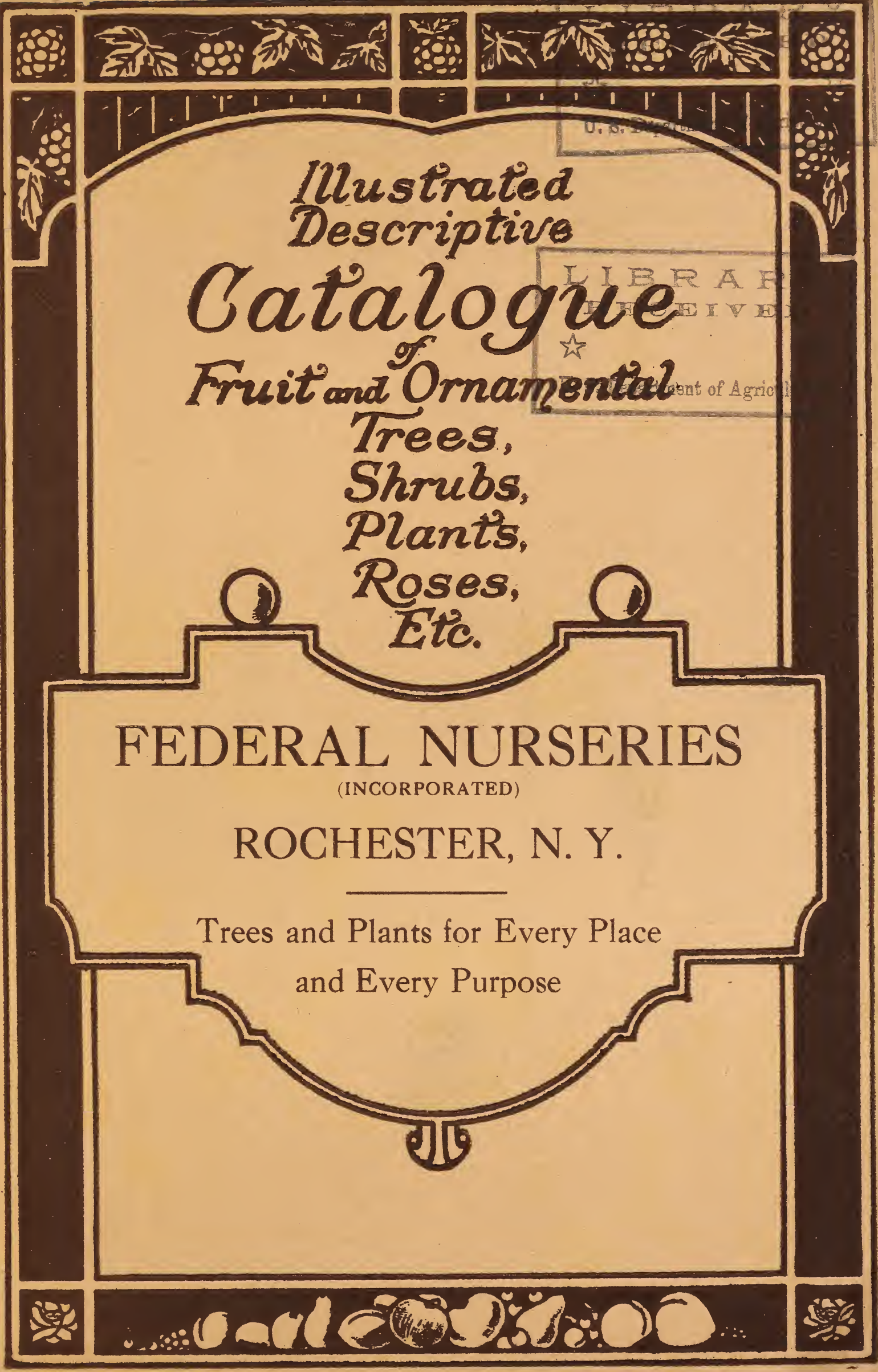




\section{Transplanting Directions}

\section{TO OUR CUSTOMERS.}

Most of the failures experienced in the planting of Trees, Shrubs, etc., rosult from a want of knowledge of conditions necessary to success, or from * careless disregard of them. Many Nurserymen are blamed for what might essily have been avoided had the planter consulted the plain wants and re. quirements of the stock and given it at least a fair chance to grow and do well. We are interested in the success of every article we send out; we take the greatest pains to place every item in the hands of our customers in the best possible condition, and in order to furnish some precautions which our experience suggests, and urge to a more cautious and considerate culture, we give a few hints on such points as are most essential.

Preparation of the Trees.-Do not let them get dry. If not ready to plant when the stock arrives, see that it is immediately taken care of. The best way is to "heel it in"' by placing the roots in a trench and covering them thoroughly with mellow earth well packed about them.

Planting.-The holes should be dug deep enough to receive the roots of the tree without cramping or bending them. The trees having been properly pruned, should be held upright and earth filld in about the roots, the finest and best soil from the surface being carefully worked among them, filling erery space.

Set the tree as irm as a post, but leave the surface filling (of the poorer soii) light and loose. Care must be taken against planting too deep. When the earth settles about the tree it should stand the same height as when in the Nursery. When set in Autumn it is well to raise a mound of earth about the trees a foot or more in height. This will keep them from being swayed by the winds or thrown out by frost during the winter; it should be removed in the spring. In planting Dwarf Trees, the stock on which they are budded, and no more, should be under ground. They will then stand firmly and not losi their dwarf character by the rooting of the standard stock.

Mulching.-This is properly done by placing a layer of coarse manure or litter from three to six inches deep about the tree, extending one or two feet further in each direction than th roots. This keeps the ground moist and of sn even temperature; renders watering unnecssary, and is in all respects preferable.

Cultivation after Planting.-Many cultirators after having been to great trouble and expense in selecting and planting trees fail by neglecting that after-care and attention which is equally essential. Caterpillars and Cauker Worms, Grubs and Borers, Slugs and Aphis, Disease and Blight must be watched for, and remedies faithfully applied. The wants of the trees must be foreseen, and a faithful effort made to ensure health and productiveness. For such caro the cultivator will le well repaid with thrifty, shapely trees and abundant crops of superior fruit.

Pruning.-Pruning, after the first year, should be varied according to the purpose of the planter, and the variety of the trees. They should be trimmed as early as possible up to the height it is intended the future head should be, that the cutting off of large limbs may not in the future be necessary. After the removal of the lower branches, till the head has reached the desired height, the only pruning needed is to remove such branches as are crossing or interfering with each other, and to keep the head in symmetrical shape and open to sun and air. Trees should receive proper shape by pruning early in the spring of each year, while they are young, and very little pruning will bo needed afterwards.

Grape Vines.-Require a dry, mellow, well-drained soil, deeply worked and well enriched, and with a warm, sunny exposure. In planting give the roots plenty of room, and settle the soil firmly about them. A strong vine may be allowed to grow the first season without pruning. In November or Decem. ber following, the growth shouid be cut back to three or four buds; the next cerson allow but two buds to grow, which should make canes seren to ten feet long and be cut back to four or five feet, ready for fastening to the trellis. Finer grapes and larger crops will be secured where there is not an excess of vine.

Berries.-Should have strong soil and be kept under constant cultiration. Mulching is of special value. Raspberries and Blackberries should have the cld canes cut out each year, and new canes pinched off when three feet high. If the position is at all exposed, it is well to raise a mound between the hills late in the fall, bend the canes over this mound and peg them down during the winter. Strawberries should be mulched late in the fall; uncover the crowns early in the spring, remove the mulch after fruiting, and spade in light dressing of manure.

Currants and Gooseberries should be mulched every spring and well pruned, so that new wood may have a chance to grow. The ground about them should be kept in good condition by manure and cultivation. The worms may be destroyed with certainty by applying White Hellebore powder shaken from a coarse bag as soon as they appear, and repeating the operation once or twice.

Roses.-Nothing repays good care better than Roses. They slould have deep, rich, well-drained soil, thorough cultivation and plenty of manure. They should be pruned every spring before the buds swell, cutting back all the last shour's growth to three or four buds, excepting Climbing or Pillar Puses. year allowed partly to cover the space desired; old, decayed branches should never remain. Climbing, Moss and Hybrid Perpetual sorts branches should never remain. Climbing, Moss, and Hoterion no protection, but the so-called "tender" varieties should be covered with leaves, straw or branches of evergreens, late in the fall. If the "thrip" ny appears it may be disposed of by applying decoctions of tobacco steeped water. Every Autumn, compost should be placed around the stems of tho plants and spaded into the ground the following yar. 


\section{APPLES}

The apple is universally recognized as the most desirable fruit of the United States, because of its great varieties of delicious flavors, nutritious qualities and nutrative value. Whether as commercial crop or for the satisfaction of the family, a well selected orchard of a few varieties is a most desirable investment for any land owner to place on his premises.

We recommend the planting of a few thrifty trees from one to three years old and from four to five feet high as such are more safely handled than older and larger trees.

\section{Summer Apples}

Chenango (Strawberry) - Rather large, oblong conic, angular; whitish-yellow striped and splashed with light crimson; flesh white, very tender, with mild pleasant sub-acid fiavor. A market and eating variety. Tree vigorous and productive.

Duchess of Oldenburg-Large size roundish; streaked with red and yellow; flesh whitish; juicy; flavor sprightly, sub-acid; market variety. Tree a vigorous grower; very hardy; succeeds in northwest where many kinds fail. August-September-October.

Early Karvest-Medium to large; pale yellow; fine flavor. Tree moderate, erect grower, and a good bearer. A beautiful and excellent variety for dessert and kitchen.

Golden Sweet-A large, handsome, yellow apple; fine; sweet; good for market. Tree rather spreading and irregular. A free and productive; August-September.

Red Astrachan-Large, roundish: nearly covered with deep crimson; overspread

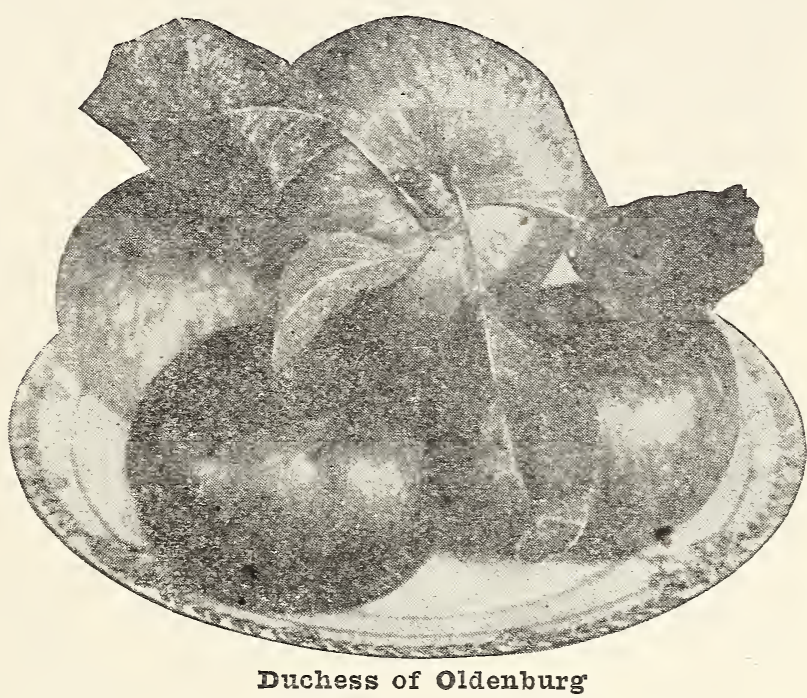

with a thick bloom, juicy, rich, acid. Cooking and eating variety suitable for market. Tree a vigorous grower with large foliage; a good bearer. August.

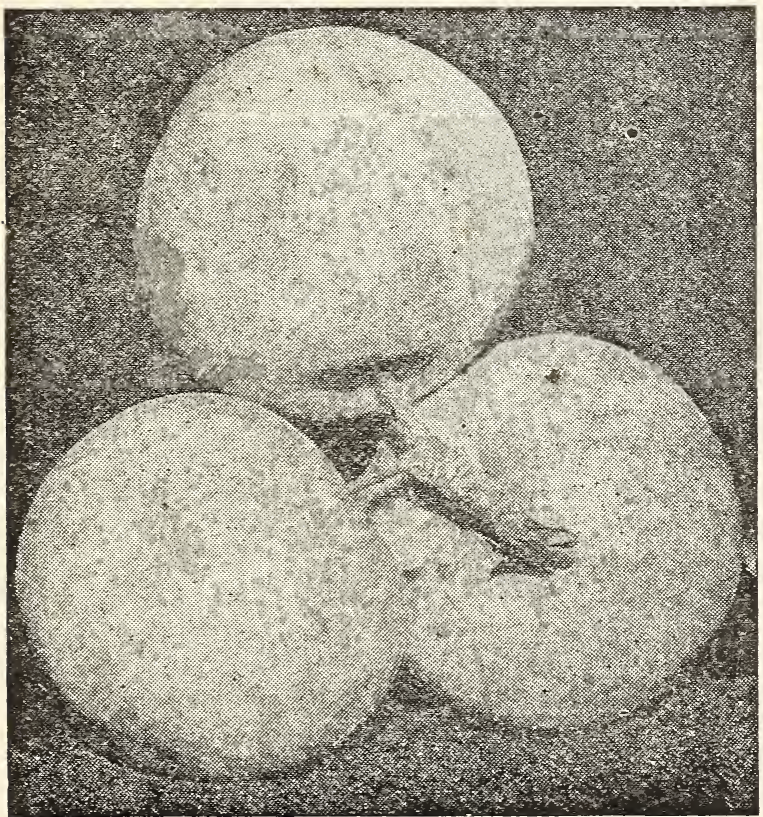

Yellow Transparent

Xellow Transparent-Good size; clear white turning to pale yellow; flavor sub-acid, highly prized for cooking and eating; popular market variety. Tree of Russian origin; upright grower; bears early and abundantly; hardy. July-August.

\section{Fall Varieties}

Fall Pippin-Very large, roundish, oblong, yellow; fiesh tender and delicious. One of the most valuable varieties for table or market. Tree z free grower and a fine bearer. October-December.

Fameuse (Snow Apple)-Medium size; pale greenish-yellow, mixed with stripes of red and splashes of red on shady side; flesh white tender and juicy; slightly perfumed, sub-acid; extra good; recommended for table, kitchen and market. An old and well known variety. Tree moderate grower but productive. October-November.

Iubbardston (Nonsuch) - Large, yellow with red stripes; flesh tender and juicy; sub-acid, very good flavor; recommended for dessert and market. Very productive. NovemberJanuary. 


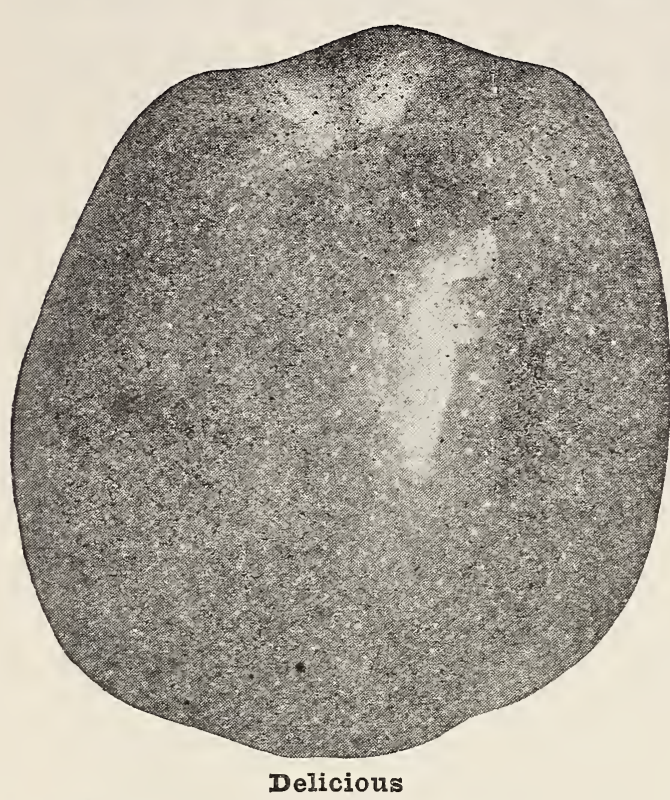

Maiden Blush-Medium size, smooth, beautifully flushed with red on creamyyellow; flesh tender, of pleasant but not high flavor. A good market sort because of attractive appearance and all-round utility. Tree a fair grower and productive. September-October.

Rambo-Medium size; oblate; smooth, streaked and marbled with dull yellowish ground; dots large, whitish; flesh tender rich, mild, sub-acid. An old variety; good for cooking or eating. Tree a great grower and very productive. Most popular in the west. October-December.

Wealthy-Medium size; roundish; smooth nearly covered with dark red; very good; dessert; very profitable as a market sort. Tree good grower and productive. OctoberJanuary.

\section{Winter Varieties}

Baldwin-Medium size; conical; bright red; flesh crisp, juicy, sub-acid; rich flavor: great market variety of eastern states for cooking, dessert and market. Tree vigorous. Open head. Abundant crops, but does not bear young. November-March.

Banana-Medium size; smooth; easily polished; deep yellow; slight blush; flesh solid, juicy; mild sub-acid; has delicate banana perfume and flavor; very popular for dessert and market.

Delicious-Flourishes well in every state of the Union. Bears annually; great yielder; hangs well on trees. Trees very thrifty, long lived and extremely hardy. Fruit very large, nearly covered with brilliant, dark red; flesh fine grained, crisp, juicy, melting and delicious; splendid keeper and shipper; should be in every orchard.

Gano (Black Ben)-Large; conical; smooth; very deep red and attractive; flesh pale yellow fine grained; mild sub-acid. A good shipper and keeper for market. Tree healthy; vigorous and hardy; annual bearer. February to May.
Grimes Golden-Medium size; regular; rich, golden yellow; flesh yellow, firm. crisp, aromatic, rich; quality very best. Top-notcher in market. Tree hardy and productive; bears early; blossoms late in spring frost seldom catches them. One of the best sorts. November to January.

Jonathan (New Spitzenberg)-Medium size; roundish; yellow, nearly covered with red; flesh white, fine grained, juicy, tender and mild; a delicious and strictly dessert apple that always demands highest market prices. Seedling of Spitzenberg. Is a much better tree; vigorous and productive. November to April.

McIntosh (McIntosh Red) - Medium large; polished; smooth; yellow, nearly covered with brilliant crimson; beautiful; flesh snow white, crisp, very tender, aromatic sub-acid; very good quality. Resembles Fameuse type, but is larger and more hardy. Tree vigorous with spreading head; a good annual bearer; popular in northwest. November to February.

Worthern Spy-Large; roundish; slightly conical; striped, with sunny side purplishred; flesh white and tender, with mild, rich, spicy flavor. An old favorite and one of the best all-round apples grown. Tree is a strong, upright grower, head very compact and should be opened up by pruning to admit air and light. December-June.

Northwestern Groening-Large; round green, turning to yellowish-green when ripe; flesh yellow, fine grained and tirm; good flavor, smooth and attractive; mard ket sort bringing high prices. Tree one of best growers in the west; extremely hardy and bears young. Blossoms early.

Rhode Island Greening-Large greenishyellow, tender juicy, rather acid but highly flavored; very popular; extra good cooker. An old standard sort. Tree vigorous and spreading; a heavy and constant bearer. December-March.

Rome Beauty-Large; round; mottled and striped in different shades of red; flesh yellowish, tender; juicy; sub-acid; recommended as a dessert and market variety. Grood grower, blooms late, productive; especially recommended in eastern state. November. February.

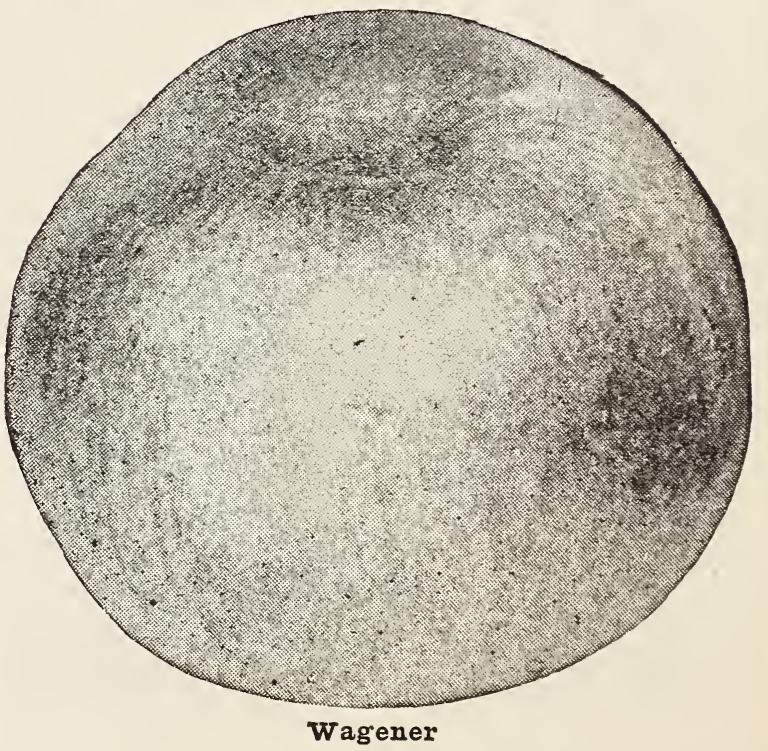


Stayman's Winesap-Medium size, roundish; greenish-yellow, red striped; flesh yel. low, firm, fine grained, crisp, juicy, aromatic; recommended for cooking and eating. Tree quick and vigorous grower, adapts itself readily to different soils and situations. November to February.

rompkins ring (King Tompkins County) - Very large; attracts attention by size; red; flesh yellowish, crisp and tender, subacid of best quality; always in demand on market. Tree vigorous grower, good bearer and hardy. November-January.

Tolman Sweet-Medium size; pale yellow; flesh fine grained, white, firm, moderately juicy and very sweet; quality excellent. Tree vigorous, upright, spreadin and very productive; one of the old eastern varieties. Decenber-March.

Wagener-Bright red apple, strongly contrasting yellow background color; medium to large; whitish flesh, tinged light yellow, firm fine-grained, juicy, -very good quality. Tree is straight, vigorous, upright grower; enormously productive, usually bears third or fourth year.

Wolf River-Very large; handsome; red on greenish-yellow skin; flesh whitish, tinged with yellow, very firm, tender, juicy and of good quality, rather acid; market sort. Tree very hardy and productive.

Yellow Bellflower-Very large; sometimes angular; pale yellow, often with a blush; flesh white, very tender when ripe, fine grained, crisp and juicy, acid, becoming sub-acid later; an old and highly recommended variety. Tree rather upright. November-February.

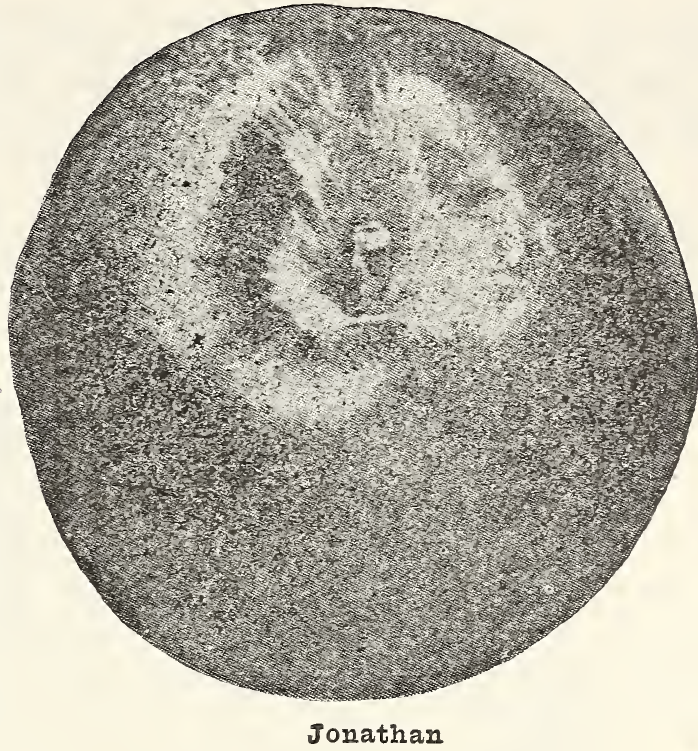

York Imperial-Medium large; often oblong; greenish-yellow, covered with bright red; flesh crisp and juicy when mellow. A great variety for cold storage market and raised in immense quantities in lennsylvania section. Tree vigorous and productive, almost equalling Ben Davis.

\section{CRAB APPLES}

Crab apples are especially desirable in the colder sections as only a few varieties of apples can be successfully grown; but they succeed well in all climates and their fruit is very popular for preserves, jelly and some sorts are excellent for eating.

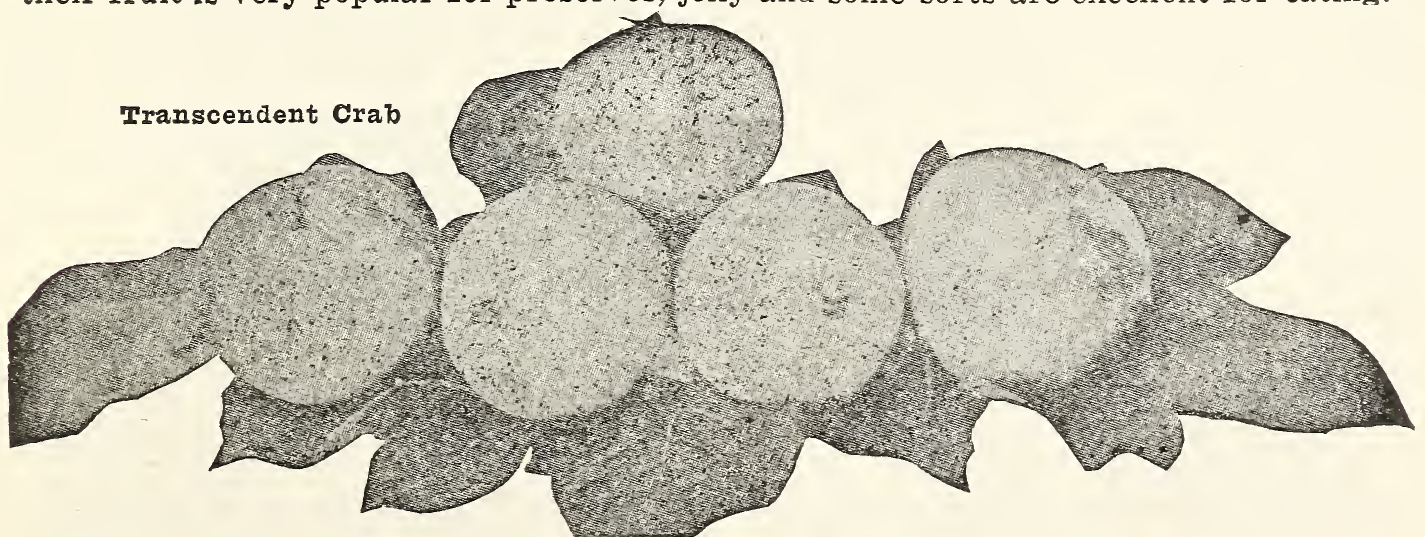

IJslop-Large, round, conical; yellow, with heavy shadings of deep crimson and splashes of maroon with heavy blue bloom; flesh fine, firm, yellow, astringent; its high color always commands a fancy market price. Tree very vigorous and hardy. blights in some localities; bears abundantly in clusters, which make them exceedingly ornamental. September-October.

Iranscendent-Medium large, oblate; golden yellow. with blush; flesh firm crisp yellowish, fine grained, very juicy and acid; when ripe is edible. It is generally grown all over the United States and is very pop- ular for cider as well as jelly and preserves. Tree grows rapid and irregular; a great bearer; subject to blight and should not be planted near other apple trees. Sept.

Whitney-Large, averaging one and onehalf to two inches; round, conical; smooth, glossy yellow, with red stripes; flesh firm juicy and rich; almost sweet; especially bred for wine and cider. Tree hardy, handsome and very productive. August.

Yellow Siberian-Small, round; yellow; flesh yellowish and acid; popular on mar. ket for jellies. Tree vigorous and hardy. 


\section{PEARS}

The pear is the most delicious of modern fruits on account of its fine, juicy texture, exquisite flavor and aroma. While some varieties do better if picked when partially ripe and finished in doors, yet the really enjoyable supply should come from the home orchard, planting a number of varieties that will ripen in succession, from fall to winter. Some points in favor of pears are, they begin bearing in a

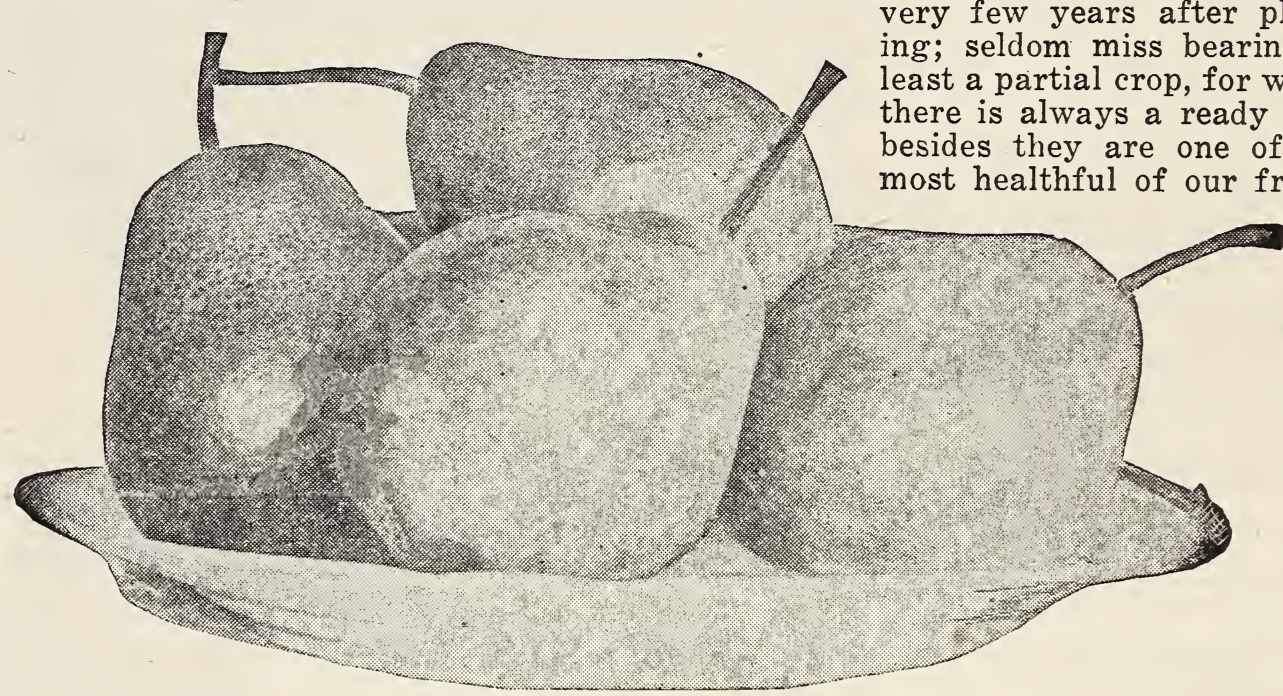

Bartlett

\section{Summer Varieties}

Bartlett-Large; rich yellow, with beautiful blush next to the sun; buttery, very juicy and highly flavored. Very popular: grown everywhere. A favorite market variety. Tree a strong grower; bears early and abundantly. Does best as a standard. Last of August and early September.

Clapp's Favorite (Fay)-Large; pale lemon yellow with red cheek; flesh of fine texture, melting buttery, juicy, with a rich vinous flavor; good for market and kitchen. Tree hardy and very productive, does well in all sections. Standard or dwarf. August.

Koonce - Medium; yellow, with red cheek, originated in southern Illinois; largely planted for market sort. Can be picked green and will color up well in a few days, Tree vigorous, bearing large crops annually. July-August.

Seckel-Medium; yellow, with crimson cheek; flesh melting, sweet and aromatic; most exquisitely flavored pear known. Tree slow grower, but hardy and healthy. Sept.

\section{Autumn Varieties}

Anjou (Buerre D'Anjou)-Large; greenish shaded with russet-crimson; flesh is highly flavored, vinous and rich; dessert and market sort; keeps well until winter holidays, when it commands a high price. Tree hardy and productive and succeeds well in all sections. October-January.

Clairgeau (Buerre Clairgeau)-Large, yellow with russet and brown sometimes shaded with crimson, flesh yellow, juicy, recommended for cooking and market sort.
Tree a yery sood grower and bears early. Standard or dwarf. October-November.

Duchess (Douchesse d'Angouleme)Very juicy, with rich, excellent flavor. An all around variety for dessert, cooking and market. Succeeds best as a dwarf.

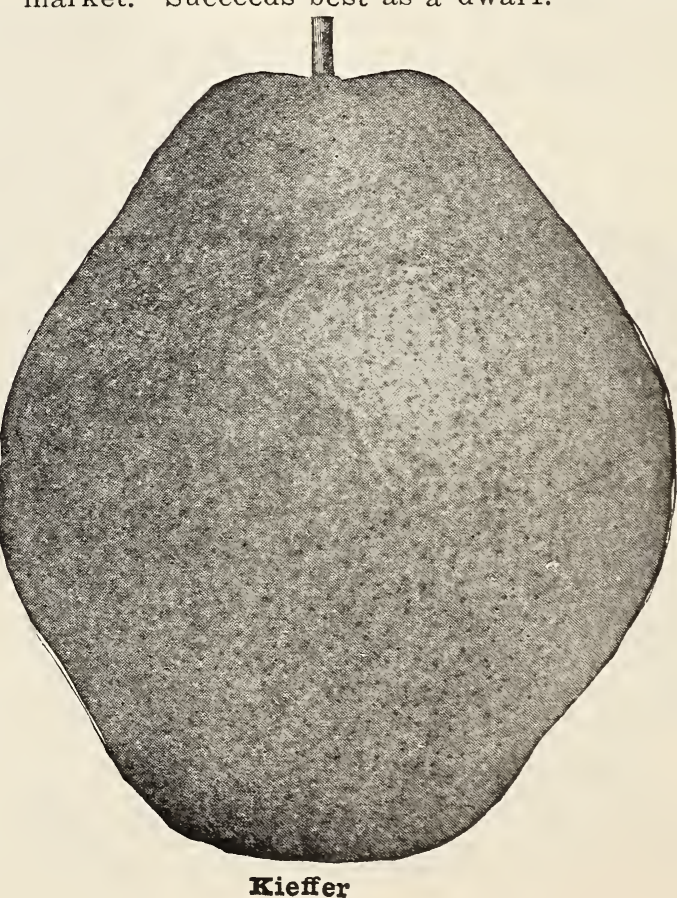




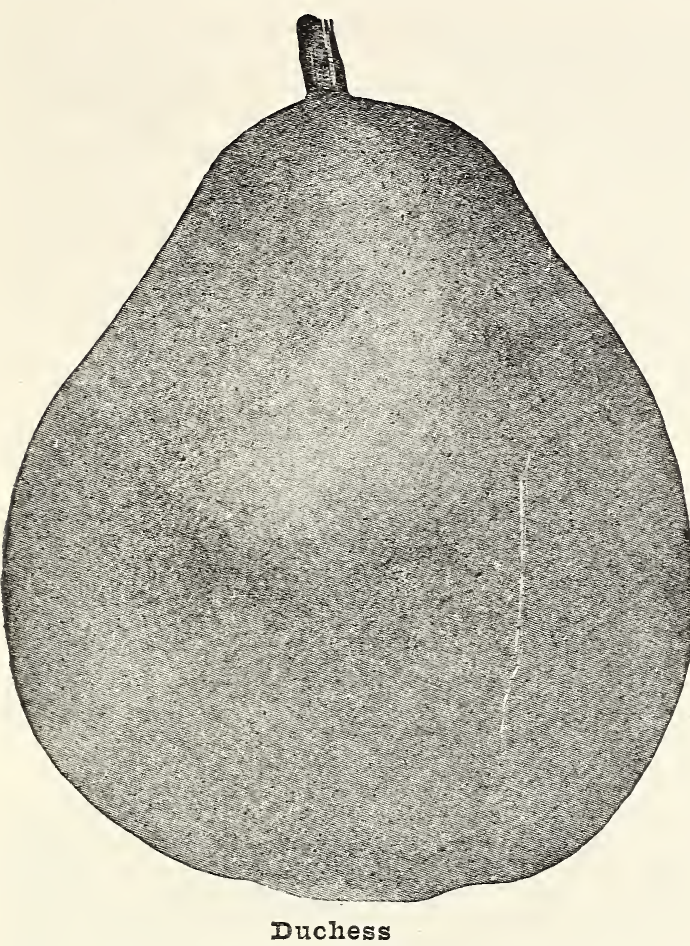

Flemish (Flemish Beauty)-Large; pale yellow, covered with light russet, turning reddish-brown when ripe, flesh juicy, very sweet, rich and melting; recommended for extreme northern states. Standard and dwarf. September.

Garber-Large; bright yellow, with red blush; flesh juicy and rich; a cross with the Kieffer, but two weeks earlier and better quality. Tree very productive and bears three years after planting. Standard. September.

Kieffer-Medium large; yellow and crimson, with russet and brown; flesh firm and good when ripe; the Ben Davis of the pear family; when properly ripened is delicious. Tree vigorous, with healthy, dark green foliage; an early bearer and very productive everywhere. October.

Worden (Worden's Seckel)-Medium size; golden yellow, with russet cheek; flesh fine grained, juicy buttery with a rich aroma; recommended highly as a dessert and market sort. Tree hardy and an enormous bearer. September.

\section{Winter Varieties}

Drouard (President)-Very large; greenish-yellow and russet; very handsome; flesh melting, juicy and highly aromatic; recommended for dessert and market. Tree vigorous, healthy and prolific bearer. February-March.

Iawrence-Medium; lemon yellow, flesh sweet, melting, aromatic: recommended as one of the very best winter sorts. Tree hardy, healthy and productive. Either dwarf or standard. November-December.

Winter Nelis-Medium; greenish-yellow, with russet; flesh fine grained, melting and rich; considered one of the most delicious and best winter sorts. Tree straggly and slender grower, but hardy and thrifty. standard or dwarf.

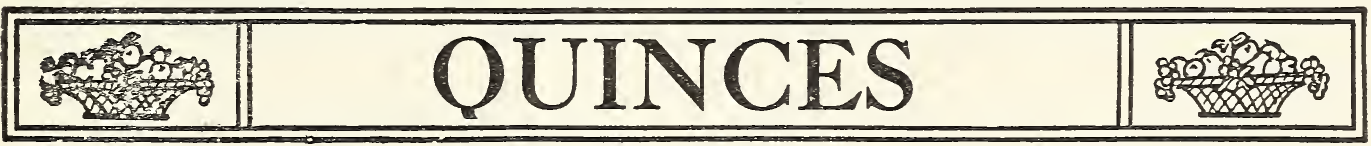

The Quince is always in demand, although its commercial value has changed but little for many years. Quinces are largely used in cooking, canning and preserving, as they have a delicious flavor. It is a reliable cropper, and requires but little care. Yet the increased size of the fruit and the quality repay well for all the extra work given them. The trees thrive in almost any soil, but prefer a heavy, moist, clay loam.

Angers-Medium size, pear shaped; golden yellow; rather acid, tree a thrifty grower and abundant bearer. October.

Champion-Very large, greenish-yellow, flesh cooks as tender as an apple and without hard spots or core; flavor delicate imparting an exquisite quince taste and odor to any fruit with which it is cooked. Trees are vigorous growers and bear heavy crops of superior fruit; one of the best for sections not subject to early frosts.

Orange-Large, bright golden yellow fine firm flesh and good flavor; one of the best for cooking The most popular and extensively cultivated of the old varieties. Oct.

Reas Mammoth-Rich, orange color, roundish, pear shape, tapering neck. Very good quality for flavoring other fruits and for baking; almost fuzzless.

All our fruit trees, shrubs and vines are guaranteed to be true to name and if a mistake should be made will be glad to rectify.

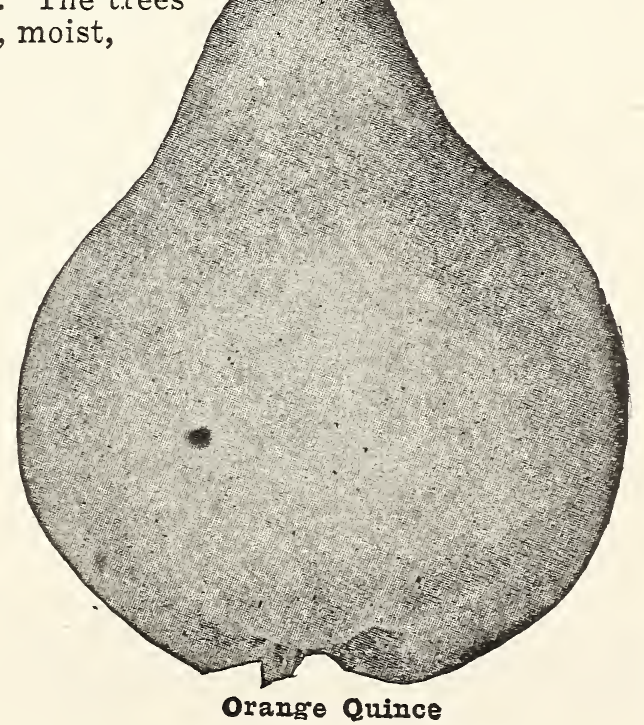




\section{PEACHES}

Every home should have a few peach trees as there is no more delicious fruit in its season, and that purchased on the market is often of an inferior quality because of the necessities of picking comparatively green. Peach trees grow quickly but are of short life and to keep a good supply of fruit, a few trees should be set out each year to replace those that die of old age or accident.

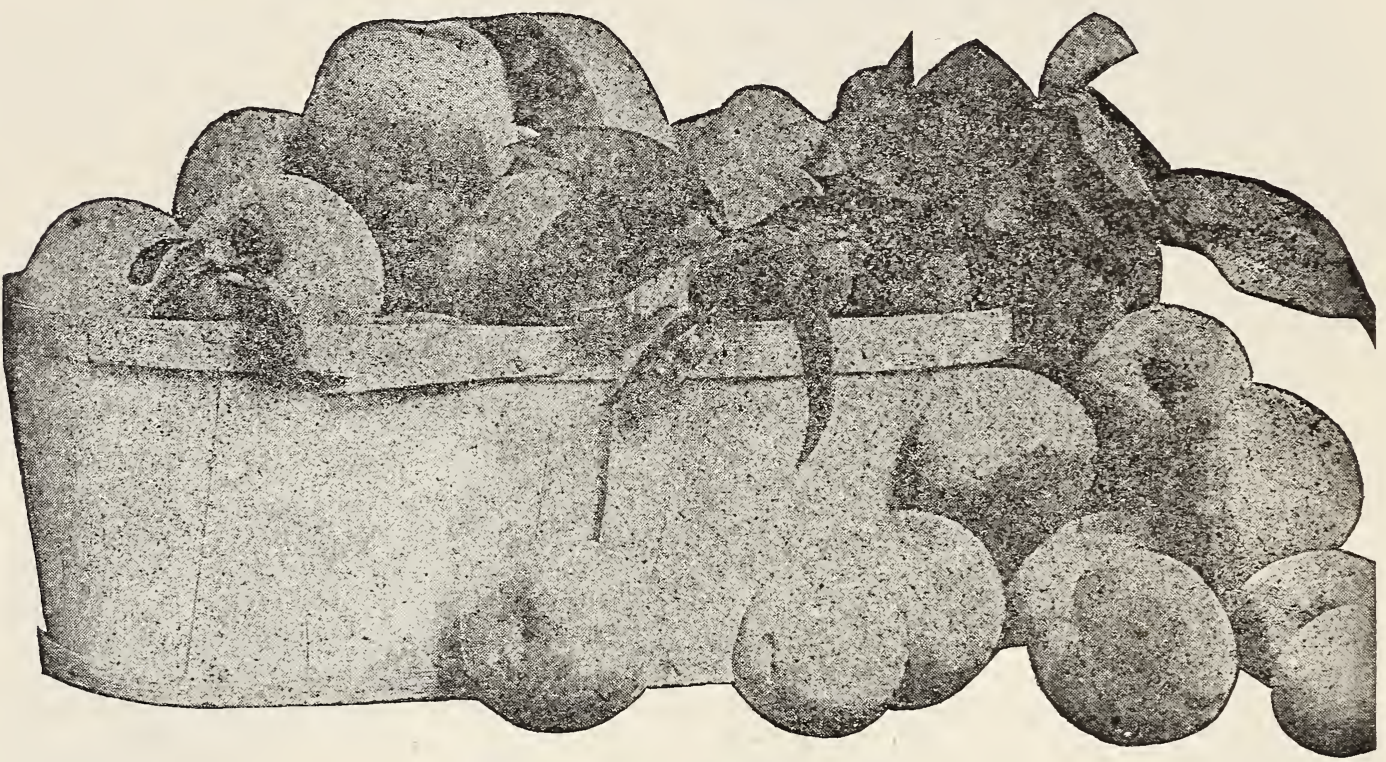

Basket of Elberta Peaches

Beers Smock-Medium large; creamy white, with crimson blush; flesh yellow, tender and rich, very good quality for the season and recommended for market. Tree a rapid grower, prolific bearer and hardy. Late September-October.

Belle of Georgia-Medium large, oblate; white, with red cheek; flesh white, firm and excellent flavor; recommended for dessert, kitchen and market. Tree a rapid grower and very productive. Early July.

Carman-Large, round; white, with deep blush; flesh tender and juicy, with fine flavor; skin very tough, making it available for marketing with profit. Tree reported very hardy and a prolific bearer. August.

Champion-Large, round, quite regular; creamy yellow, with red blush; flesh white with red stains around pit; flavor delicious, sweet and juicy. Tree very hardy and productive. First of September.

Crawford's Iate-Large; yellow or greenish-yellow, with dull red cheek; flesh yellow, stained red at pit, melting, vinous and very good. Tree hardy and productive, usually needs thinning to make good size fruit. Last of September.

Crawford's Farly-Large; yellow, with red cheek; flesh yellow, juicy sweet; its size and beauty make it very popular. Tree vigorous and productive, but buds are very tender. First of September.
Crosby-Hardy in tree and bud. Golden orange color; firm but tender; very good quality; medium size. A good canner. Late.

Dewey (Admiral Dewey)-Medium size; yellow; flesh firm, yellow and delicious; good shipper; highly recommended as a very early sort. Tree is strong, hardy, symmetrical grower and produces well. July.

Fde (Captain Ede)-Very large; yellow, tinted with red; flesh yellow and about same quality as Elberta; claimed to be hardier than Elberta and as good a market sort. August-September.

Elberta-Very large; red blush; flesh yellow with pale yellow, tender and juicy; the great market peach of the country. Rank, vigorous grower, does well in all peach growing sections. Middle September.

Greensboro-Medium; yellow, with beautiful blush; flesh white, juicy and good; freestone when fully ripe; said to be larger than Alexander. July.

Fale's Early (Semi Cling)-Medium size greenish white, with red cheek; flesh white melting and juicy. Tree vigorous and healthy; an abundant bearer. July-August.

Kalamazoo-Medium to large; oval; yellow, striped with red and a thin bloom; flesh yellow, red at pit; rich, vinous and of good quality. Tree a strong grower and bears at two years old; hardy and reliable. September. 
Iremon Free-Medium large, roundish; often with pointed apex; light yellow with greenish-white tinge and thick bloom; flesh yellow, tender and good; a good canning sort. Tree a regular and prolific bearer. October.

Mayflower-Medium size; practically red all over; flesh firm and of good flavor; extremely valuable as a very early market sort, especially in southern states. Tree blooms very late; upright and good grower; prolific bearer. Earliest known.

Rochester-Free. An excellent new sort. Large size red skin yellow flesh, good flavor. Early producer; heavy cropper. August 10.

Smock-Large, roundish, somewhat oval; yellow, with some blush and thick bloom; flesh yellow, tender and sprightly. A good market sort.

stump-Very large, roundish; white, with a red cheek, considerable bloom; flesh white, juicy and good flavor. Tree very prolific. Last of September.

Triumph-Medium large; dark yellow, nearly covered with red; flesh yellow nearly to pit, where it changes to greenish-white; juicy, melting and sub-acid; an attractive market sort. July.
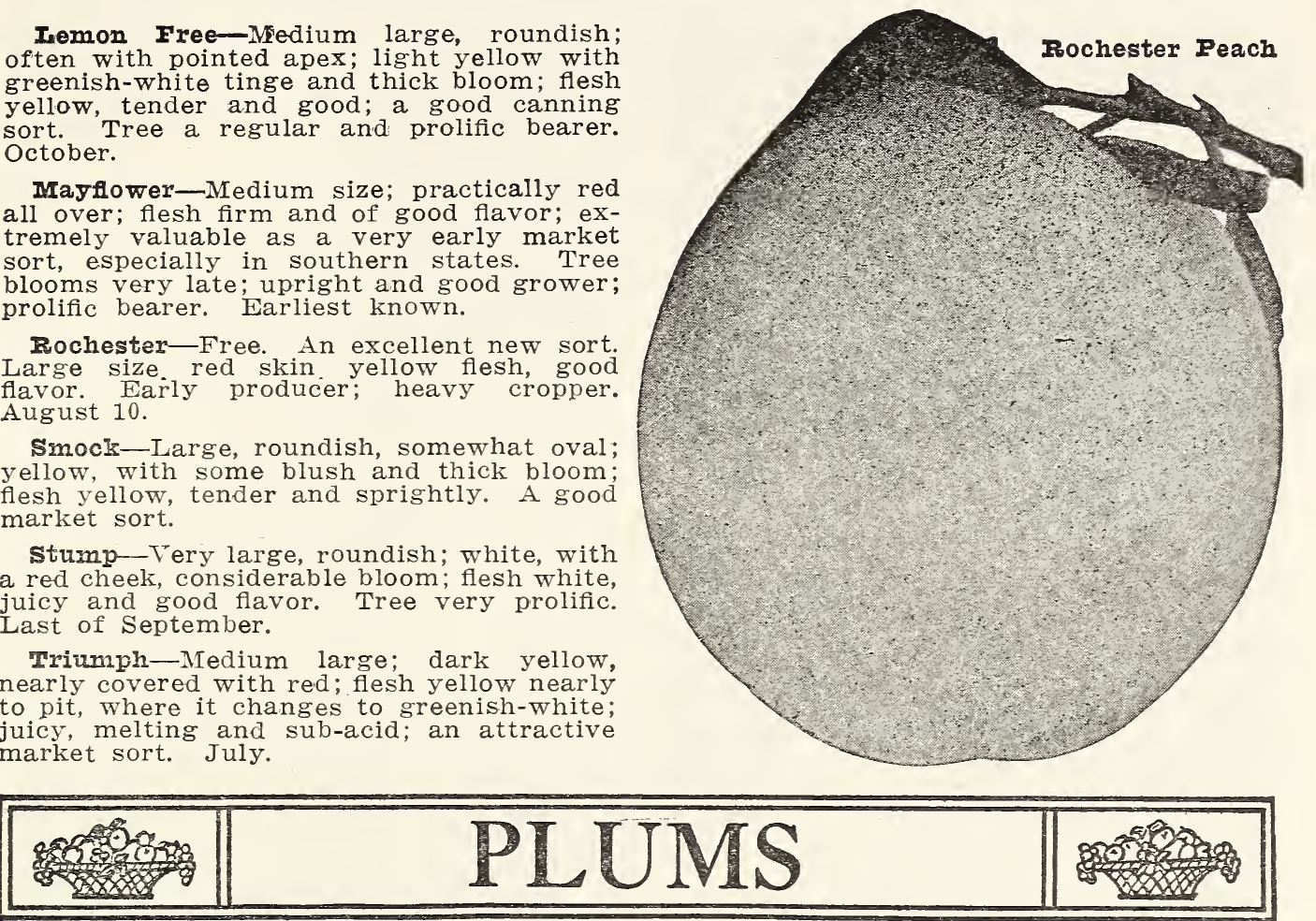

The plum, like a pear, succeeds best in a rather heavy soil with some clay and being generally free from disease is profitable. They should be gathered a few days ahead of use that they may develop their perfect flavor. For family use they especially do well in poultry yards, or where the hogs keep the ground free from fallen fruit. The varieties should be mixed.

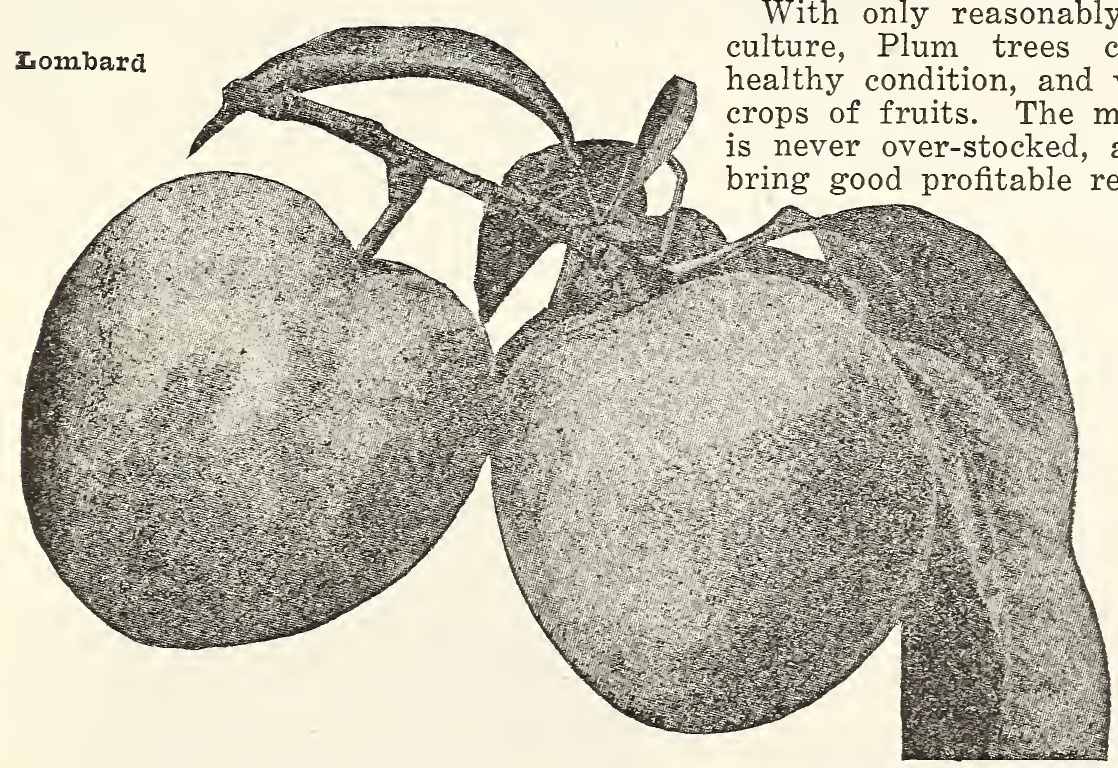

\section{American Varieties}

Gueii (Blue Magnum Bonum, N. Y.)Medium; bluish purple; cling, flesh yellowish-green; rather coarse; sweet pleasant flavor; a great market sort. Tree hardy, very vigorous and upright grower. September.
Shropshire (Damson, Eng.)-Small; black or blue; cling; flesh rather coarse, popular in market for kitchen use. Tree is not a rapid grower, but fruit grows abundantly in thick clusters. October.

York State Prune-Large size; blue; delicious; one of the best in quality and most productive of all prunes. Freestone. A vigorous grower and hardy. August. 


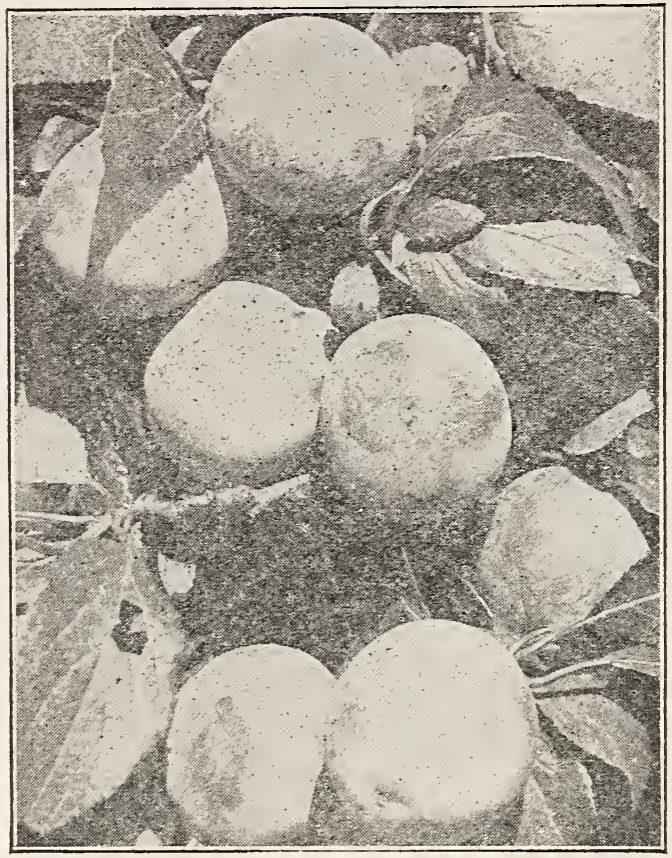

Abundance

Domestic Varieties

Bradshaw (Niagara, Amer.) - Medium large; purplish-red; free; flesh green and juicy; good shipping qualities. Tree an upright grower, bears regularly; enormous crops. Medium early.

Damson (Europe)-Small; black, with thick blue bloom; free; flesh juicy, but rather tart; best for kitchen and market. Tree enormously productive and hardy. September.

Green Gage-Small but of highest excellence; skin greenish yellow; flesh yellow, juicy and of fine flavor. Late september.

Imperial Gage (N. Y.)-Medium; yellowish-green; heavy white bloom; free; flesh juicy, sweet, rich and excellent; one of the very best dessert and market. Tree upright and vigorous. September.

Italian Prune (Europe)-Medium large; purplish-black; blue bloom; free; flesh greenish-yellow, juicy, sweet and of good quality: will hang on tree after ripening; quality; will hang on tree after ripening; very productive. September.

Iombard (N. Y.)-Medium large; reddishviolet, with heavy bloom; cling; flesh firm, yellow and very pleasant for both kitchen and market. Tree unusually vigorous, succeeding well on even light soils. Late August.

Yellow Fgg (Europe)-Very large; greenish-yellow; flesh a little coarse but recommended for drying and cooking. Tree a free grower and very productive. Late August.

\section{Hybrid Varieties}

Abundance (Japan)-Medium to large; a rich cherry red; with a decided white bloom; cling; flesh light yellow, exceedingly juicy, tender and delicious; kitchen and market. Tree vigorous and hardy; rapid grower and bears young. Last of July.

Burbank (Japan)-Large; reddish-purple; cling; flesh yellow; juicy; good for kitchen and market. Tree rather spreading and abundant bearer; very hardy and prolific. Medium late.

Compass Cherry-Small; purplish red, with large pit, flesh yellow and very good for cooking. The original cross of Minor Plum and Sand Cherry.

Fanska-Beautiful color, bright red, with heavy bloom; flesh firm, yellow and good quality; fragrant; apricot flavor; tree tall, rapid grower; pit small.

Red June (Japan)-Medium; vermilion red with bloom; semi-cling. flesh light lemon yellow; slightly sub-acid; but good quality for kitchen and market. Tree strong and spreading; unusually productive. Early.

Shipper's Pride-Large; purple; flesh firm sweet and excellent for shipping and kitchen. Tree hardy and productive. September

Wickson (Calif.)-Very large; reddishpurple with white bloom; cling; flesh firm and meaty; yellow, rich, aromatic; a market sort. Tree strong and spreading; bears abundantly and early in most localities. August.

\section{APRICOTS}

Alexander (Russian)-Medium to small size; light orange flecked with red; flesh tender juicy; sweet and good flavor: dessert and market. Tree hardy and productive. July.

Farly Golden-Small roundish-oval; pale orange with smooth skin; flesh yellow; juicy, sweet and desirable for dessert use. Tree hardy and productive.

Moorpark-Very large; orange-yellow with numerous specks and dots; flesh yellow, sweet, juicy and rich; good to very good market and dessert. Tree is rather tender and fruit ripens unevenly. August.

\section{MULBERRIES}

Downing-Highly ornamental for street or lawn, bearing an abundance of large black, sub-acid fruit. Its long bearing season makes it a universal favorite whereever it is grown.

New American-Equal to Downing in all respects and a much hardier tree. It bears fruits of the finest size and flavor from mid-July until Autumn.

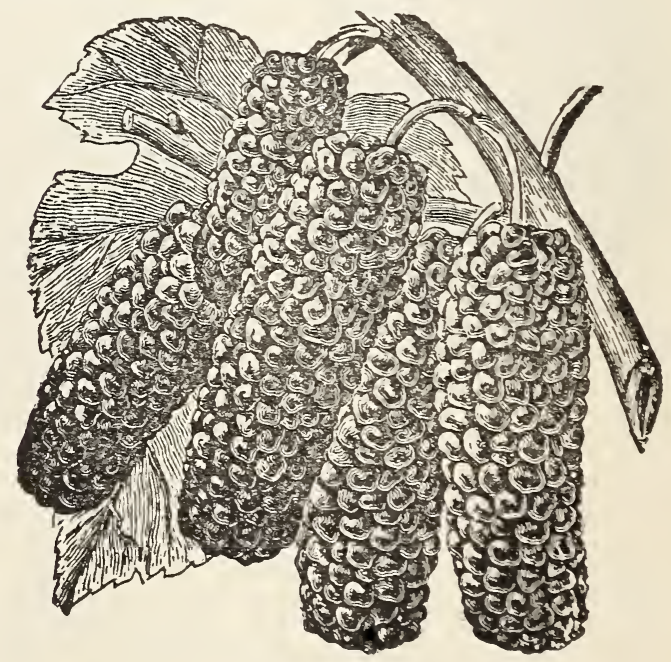

New American 


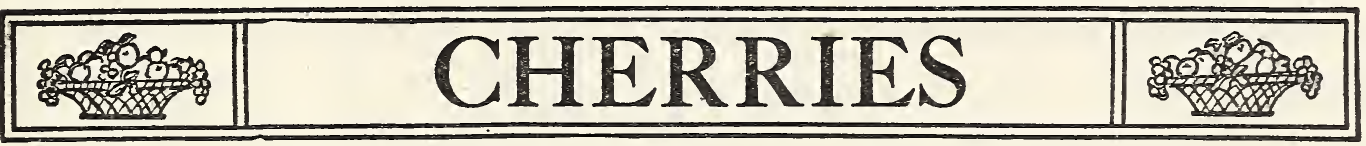

While the cherry tree is of rather slow growth it is so sturdy and hearty and bears for so many years a large, bountiful crop under the most adverse conditions, that a few of them are the most valuable tree that a home man can plant. Where room is available a few of the sweet varieties is very desirable, but owing to their uncertain cropping, sour varieties should also be included among the selections. Sweet varieties thrive only in favored localities, also they require particular care and attention, especially in spraying. But the sour cherry can be grown almost anywhere. It makes a fine ornamental windbreak, gives great satisfaction in the home garden, and offers great possibilities for profit for the grower who supplies the local markets.

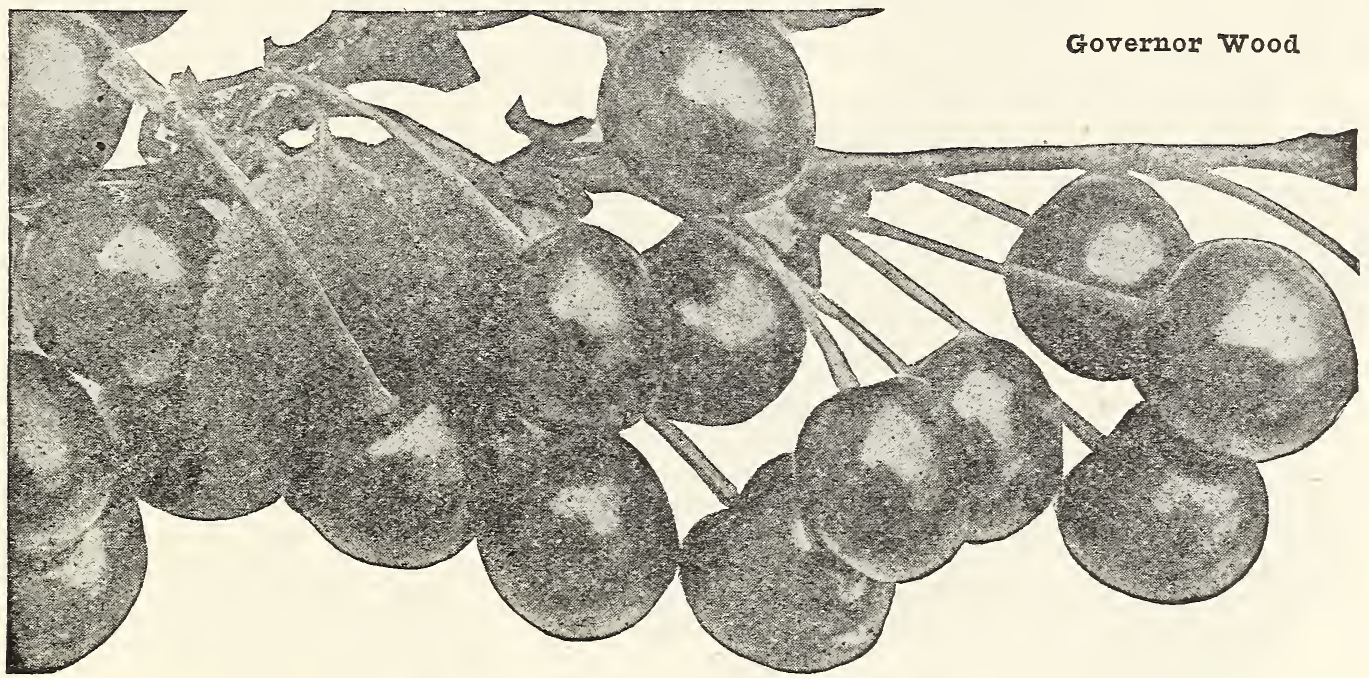

\section{SWEET VARIETIES}

Bing-Fruit large, dark brown or black one of the most delicious late sweet cherries on the Pacific coast; is considered one of the most profitable. Tree hardy and vigorous; seems to succeed east better than most sweets. Late.

Governor Wood-Large, round, dark heart-shaped; yellow, mottled with red; flesh sweet, juicy and delicious. Fruit hangs well on tree. June.

Napoleon-Yellow, with a bright red cheek; very large; long, heart-shaped; firm flesh. Meaty crisp, mild and sweet; high quality. Tree is a hardy, vigorous, upright grower, with strong. sturdy limbs. Very productive and bears young.

Schmidt (Smith's Bigarreau)-Very large dark reddish-black; flesh dark, tender, very juicy with a fine flavor. Tree vigorous.

Spanish-Large, pale yellow with red cheek; flesh firm and juicy. One of the best light colored cherries for dessert. Tree very productive. June.

Tartarian (Black Tartarian)-Very large; purplish-black, heart-shaped; flesh mild and sweet and quality considered the very best for market and dessert. Tree is a vigorous, upright grower and immense bearer. July,

windsor-Large, dull red; flesh very firm, and fine quality; good bearer. No cherry in recent years has attracted more attention. Has been recommended by some of the most prominent fruit growers of the country.

\section{SOUR VARIETIES}

Farly Richmond-Medium size, dark red; sprightly acid flavor. This is one of the most valuable and popular of the acid cherries, and is unsurpassed for cooking purposes. Tree a splendid grower and is exceedingly productive. The most hardy of all varieties. Ripens through June.

English Morello-Very dark sour cherry; latest to ripen. One of the best cooking cherries. Dwarfish-growing tree. Especially good for garden planting.

Iate Duke-Medium large, short, heartshaped; light red; flesh light colored, subacid with a good flavor. A kitchen cherry of the very best quality. Tree strong. an upright grower; bears well. Last of July.

Iouls Phillipe-Large size, flesh red, tender, juicy, with mild sub-acid flavor, very vigorous and productive; of great value. A native of France.

Montmorency (Large)-Large. round, handsome red; flesh fine flavored, sub-acid; rich. Recommended for kitchen and nearby market. Tree good grower, hardy, productive. Late June. 


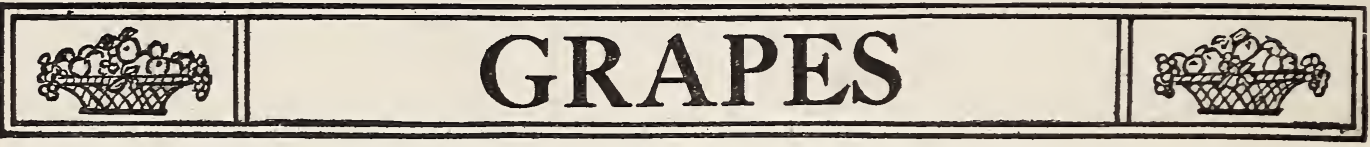

Grapes are one of the most productive and hardy fruits that we have. They can be grown in small spaces and trained up the sides of buildings or along fences, occupying very little room. Make the soil mellow and plant vines somewhat deeper than they stood in the nursery and about 8 feet apart by a fence or building. As a commercial crop they are as desirable as corn and as staple on the market. When a vineyard is once established it will be very productive for a lifetime with ordinary care. Poor soil should be given a liberal application of rotten manure.

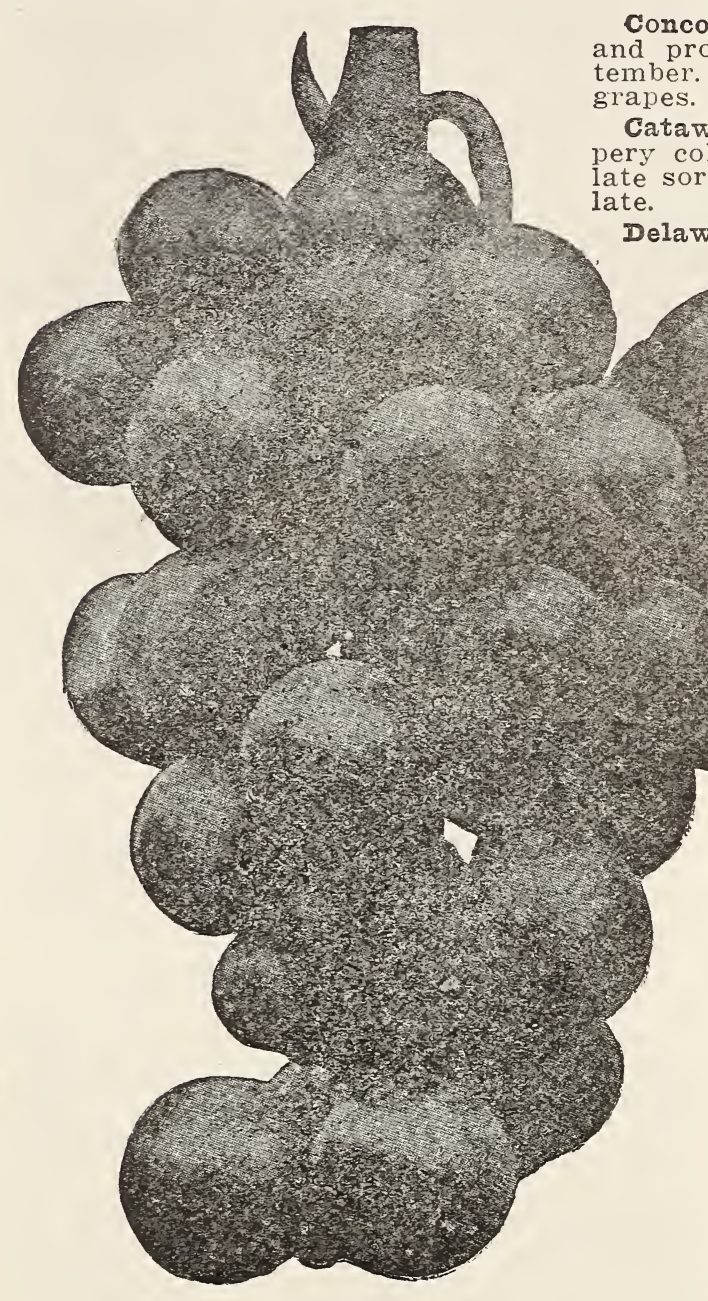

Concord

Agawam-Large round, early, dark red or brown berries, meaty and free from sour pulp; has tough skin and bees never attack it; in flavor it is sprightly, moderately sweet. Midseason.

Brighton-Medium in size, red; flesh rich, sweet and one of the best quality. Ripens earlier than Delaware. Vinous, vigorous and very hardy. Early.

Campbell (Campbell's Early)-Large size glossy black color, pulp sweet and juicy, seeds small, few in number and part readily from the pulp, clusters very large; an excellent keeper and shipper. Early.
Concord-Large, purplish black grape; very hardy prodive, ripening about the middle of Sep-

Catawba-Berries large and round, reddish-copColored; flesh fine flavored, sweet. An excellent . elaware-Berries rather smail, round, skin thin, light red, flesh juicy without any hard pulp; sweet and spicy and delicious flavor. Vine moderately vigorous, hardy and productive. Midseason.

Diamond (MFoore's Diamond)-Large delicate, greenish-white with a vellowish tinge when fully ripe; few seeds, almost free from pulp, excellent quality. Tine like Concord in growth and hardiness and foliage; the leading early white grapes.

IMoore's Early-Very large, round; a black with a white bloom; quality very fine and is classed as better and sweeter than Concord. Extremely hardy and productive.

Niagara-Large, slightly oval; pale yellow with a white bloom; the quality is equal to that of the Concord and is the standard white grape of the country. The bunches are large and compact. Vine vigorous, hardy and very productive.

Van Iindley-Handsome light red; sweet, tender, good quality. A good keeper and shipper though poor self-pollenizer. Hardy, valuable.

Worden-Large, round; black; flesh has a flavor unlike any other grape; delicious and melting; a dessert and market sort considered superior to Concord in every way. Vine hardy and productive Early midseason.

Woodruff-Large round; red; handsome; quality very good and recommended for both dessert and market. Vine a strong grower, healthy and hardy. Early mid-season.

\section{ASPARAGUS}

This delicious and healthful vegetable should be found in every garden. Nothing can be more easily grown and no plant will give so much good, healthful food for so little outlay. Set in the fall or spring.

Bonvallet's Giant-An improved Palmetto producing stronger, more vigorous shoots. Extremely rust-resisting and coming into bearing sooner and bears longer in the season than any other variety.

Palmetto-Plants vigorous in growth, producing large, thick, dark green shoots with a distinctly pointed tip. 


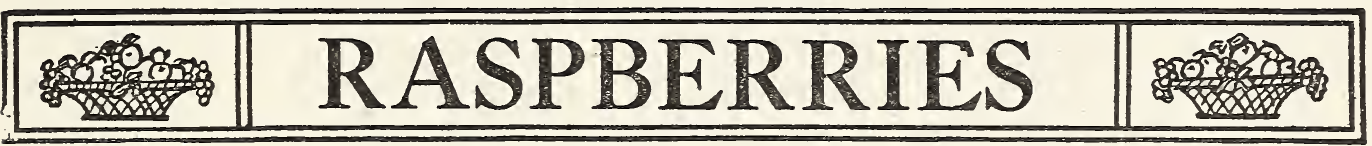

Raspberries are one of the most delicious and popular fruits grown, are easily cultivated and require little care. Cut out old and weak roots each year. Plant in good soil in hills about 4 feet apart. With a little care and attention they will produce large crops of berries. In large plantings it is advisable to plant them thickly the same as hedge row.

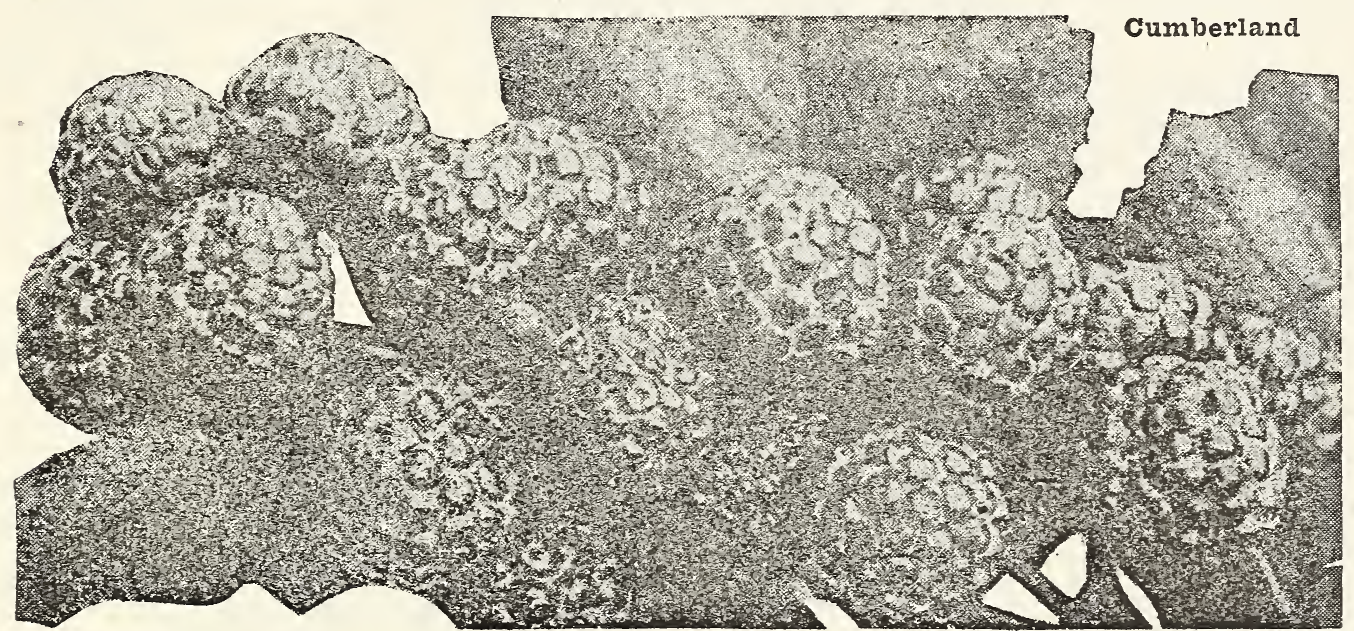

\section{Black Varieties}

Cumberland-The largest of all the blackcaps; coal black berries; very firm and the quality of the very best; excellent shipper. Bush is a strong grower, stocky canes and unusually prolifc. Midseason.

Gregg-Large; black, covered with a bloom; quality excellent for shipping, evaporating and general use. Bush hardy and favorably known in every district; productive. Midseason.

Kansas-Very large; black: a berry of splendid quality for general use and popular on the market. In many sections it is the leading sort for extensive planting on account of its vigorous and healthy growth, and prolific bearing. Midseason.

Plum Farmer-Large sweet and juicy, but firm; very attractive and recommended for all purposes. Matures fruit in short time.

\section{Red Varieties}

Columbian-Very large; deep purplishred; sweet and highly flavored; for kitchen and market. Bush very vigorous and a large grower. Needs extra room as it is very productive. Early.

Cuthbert-Very large; conical rich crimson; very handsome and firm; flavor sweet, rich and luscious; a great market sort and will stand shipping long distances. Bush hardy, both north and south; stocky, upright grower and productive. Midseason:

Eaton-Very large; rich red; flesh firm and of excellent texture for shipping. Has sprightly and exquisite flavor. Strong, sturdy grower and very productive.

Golden Queen-Medium large; clear amber yellow with highest quality; for dessert and kitchen; one of the best yellow berries ever introduced. Bush vigorous, hardy, upright and productive.
Terbert-Originated in Canada. Stands severe winters. Fruit large, bright crimson; unsurpassing quality: rich sugary of true raspberry flavor. One of the best market berrios.

Faymaker-Very large; a bright purplish-red; excellent flavor: delicious for table use and splendid for canning and shopping. Bush vigorous, hardy and iree from disease and a good producer. Recommended as profitable.

Xing-Large; crimson; firm; good flavor and desirable for dessert and market: stands shipping excellently. Bush hardy and very productive. Early.

st. Regls-Raspberries for four months. The new everlasting variety. It gives a crop of fruit all summer and autumn fruiting on the old canes in generous quantities until late in August. By this date berries begin to ripen on the young canes and con tinue until late in autumn. Berries are a bright crimson of large size, and of surpassing quality rich, sugary with full raspberry flavor. It succeeds upon all soils, whether light and sandy or cold heavy clay and the canes are absolutely hardy.

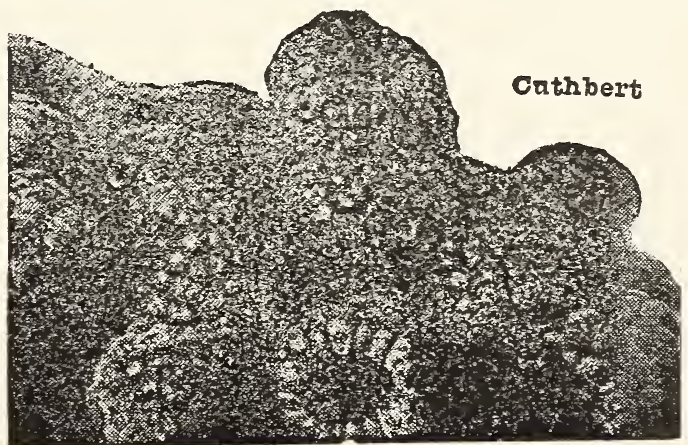




\section{BLACKBERRIES}

We grow our blackberry plants from root-cuttings, and in this way get plants with plenty of fibrous roots, which make sure the growing of the plant. In fruiting patches of blackberries there will spring up many plants from the root, and these are the plants that are usually dug up and sent out to the trade. They have but few, if any, fibrous roots, and are much more apt to die when planted, and will not make the growth after planting that the plants will when grown from root-cuttings.

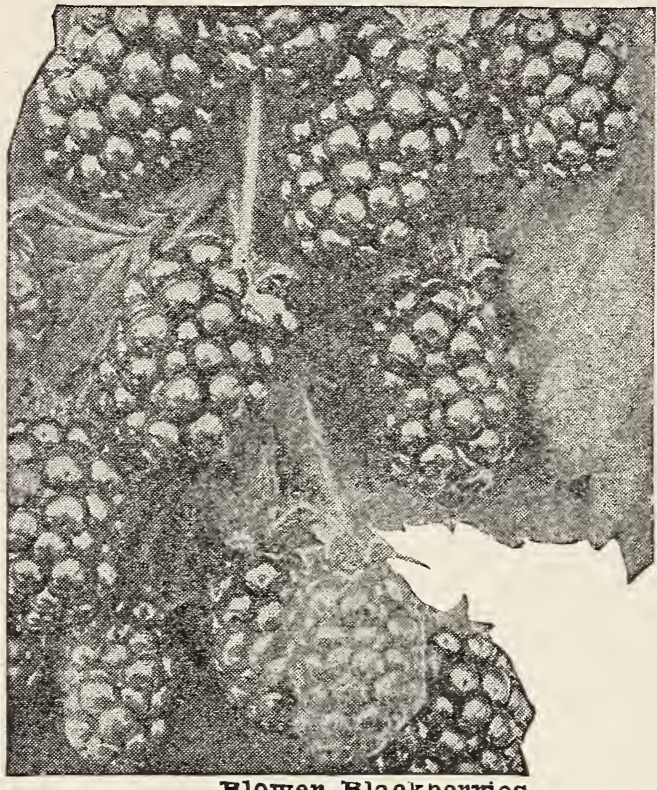

Blower Blackperries

Blower-Claimed to be the hardiest, most productive, the finest quality and for market to bring the highest price of all blackberries. Large size, jet black, good shipper, best quality and unexcelled productiveness are the main characteristics of this splendid new sort.

Early Harvest-Good quality; firm; extremely productive; attractive on the market; an early sort.
Eldorado-Large; black and do not turn red on exposure to sun; sweet and melting having no hard cores, and a good keeper. Vines hardy and vigorous.

Mersereau-Large, jet black; extra quality. very sweet; without core; unsurpassed as a shipper and keeper. Remarkably strong grower, claimed to be the hardiest blackberry.

Snyder-Medium size, sweet, melting; extremely hardy and wonderfully productive; no hard, sour core; half as many thorns as Lawton or Kittatinny, and nearly straight and short. A good market berry and shipper. Always dependable. Early.

Stone-Medium size, juicy, sweet, fine flavor, good quality. This variety should receive cultivation and be thoroughly pruned; it sets more fruit than can mature properly under ordinary cultivation; particularly adapted to northern Minnesota and similar latitudes.

\section{LOGANBERRY}

Iogan-The Loganberry is a hybrid between the raspberry and blackberry. The color is clear dark red. It partakes of the flavor of both the blackberry and the raspberry; very delicious; seeds small, soft and few. Ripens early, just after strawberries. Largely planted West.

\section{DEWBERRIES}

A variety of blackberry that trails on the ground.

Iucretia-Large, jet black, highly flavored and hardy; berries ripen before raspberries are gone, sweet and luscious throughout with no core. The best, most dependable and profitable of all Dewberries grown. The Lucretia Dewberry has received the highest praise from the best horticulturists in the country.

\section{GOOSEBERRIES $\|$ G}

Gooseberries should be planted in good, rich soil and well manured once a year. Pick regularly, thoroughly cutting out all dead-wood and surplus branches. Plant in rows 4 feet to 6 feet apart in row. It is well to mulch heavily in the fall. Plants are hardy, rugged and easily grown.

Chautauqua-Very large; greenish-white; thin skinned, sweet and of the very best quality for kitchen and market. Bush vigorous, hardy and free from mildew. Midseason.

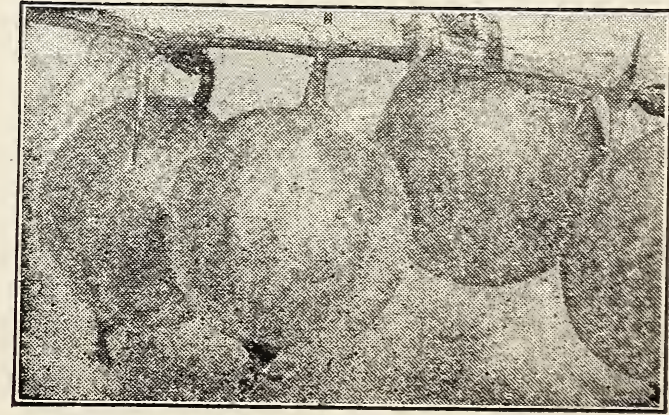

Downing Gooseberries 
Downing-Large; roundish; light green, with distinct veins; skin smooth; flesh soft and juicy and very fine flavored; highly esteemed for home use and market. Bush vigorous and productive. Midseason.

Houghton-Medium; roundish; pale red; tender, sweet, very good, and berries are very deliciously flavored. Very profitable for canning or for catsup. Midseason.
Industry-Very large; red; hairy ; fine quality; excellent flavor; extensively planted for market. Bush upright, strong and productive. English sort and somewhat liable to mildew. Early.

Josselyn (Red Jacket)-Large, pale red when ripe; oblong; very highly flavored. Bush a strong, vigorous grower; hardy and a wonderful cropper. Early.

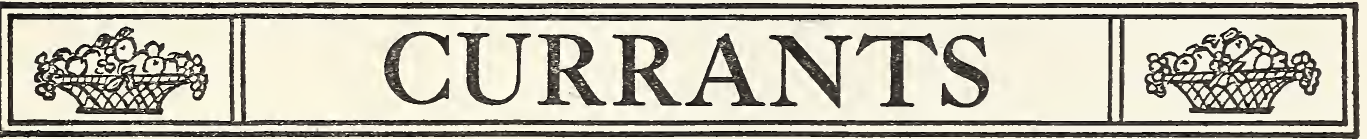

The currant is one of the most reliable of small fruits. They mature just before raspberries and can be used either raw or cooked. Being hardy, they do not winter kill, are easy of cultivation and require little care. They can be grown in any good garden soil. The market is never over-supplied. Prune out dead wood, and mulch heavily. If currant worms appear dust with hellebore.

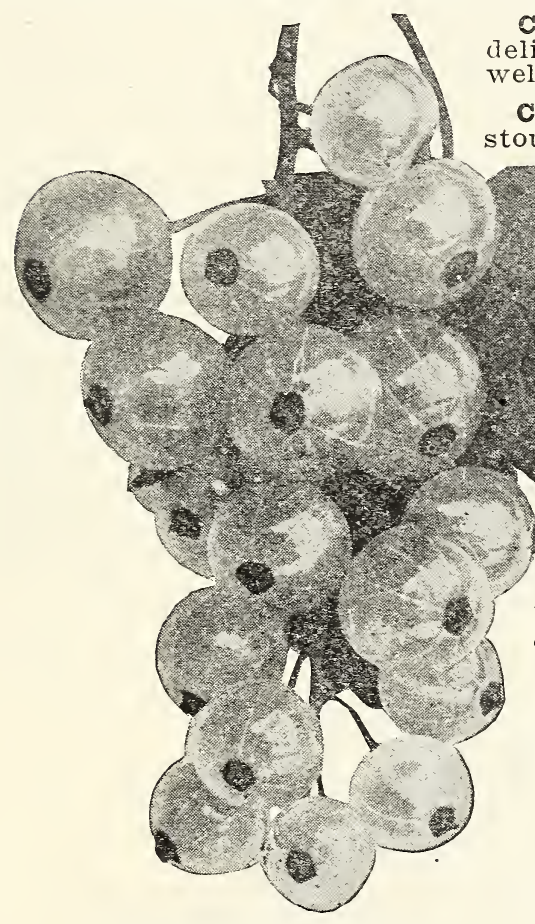

White Grape Currant

Champion-Very large; black; flavor of fruit particularly delicious for kitchen and market. Bushes large; fruit hangs well on the bushes and bears severe pruning without injury.

Cherry-Very large; red; rather acid; bushes short, erect, stout, vigorous and productive.

Fay-Very large; red; fine flavor; a great market currant; universally praised. Bush a cross between Cherry and Victoria, and very prolific.

Iondon-Rather small; red; excellent for market and kitchen; ships any distance. Bush hardy and is planted extensively in northern climates; retains its foliage; long clusters and productive.

Perfection-Large; upright red; quality very superior, rich, mild, sub-acid. Bush good grower and healthy foliage; long clusters and productive.

White Grape-Large; white; sweet or mild, sub-acid, very good quality and popular for dessert and kitchen and well known in market. Bush low and spreading. Dark green foliage; very productive.

Wilder-Very large; bright red and attractive; a splendid market sort; not so acid as most. Bush very productive; large bunches; ripens rather early; fruit keeps well.

\section{RHUBARB}

IMyatt's Iinneaus-Leaf stalks large, tender, juicy, productive, quite early.

Queen-The extra large, tender stalks are a decided pink color; delicious for cannins, cooking; strong grower.

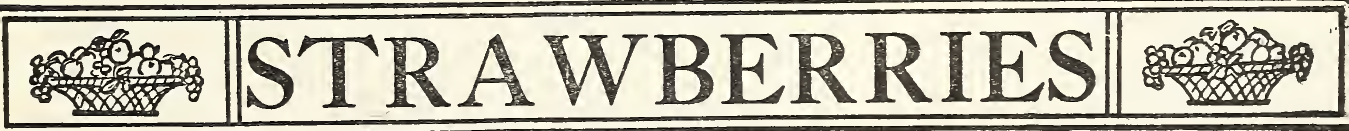

Strawberries are one of the most common and extensively used varieties of our small fruits and as a commercial proposition are grown in large quantities at very satisfactory profit. Are most fully enjoyed when picked fresh from the vine fully ripe. Growing them presents many problems that makes it an interesting occupation of itself, but it is by no means hard to secure wonderful results. It is a great fruit for large profits on small spaces and deserves the cultivation by every person having ground which can be utilized.

Everbearing varieties are receiving a great deal of attention and berries were being picked in Michigan this year all through the fore part of October. The Everbearing berries should be transplanted each year in order to insure their fruiting, but the extra time and attention is well repaid for by the luscious results. 


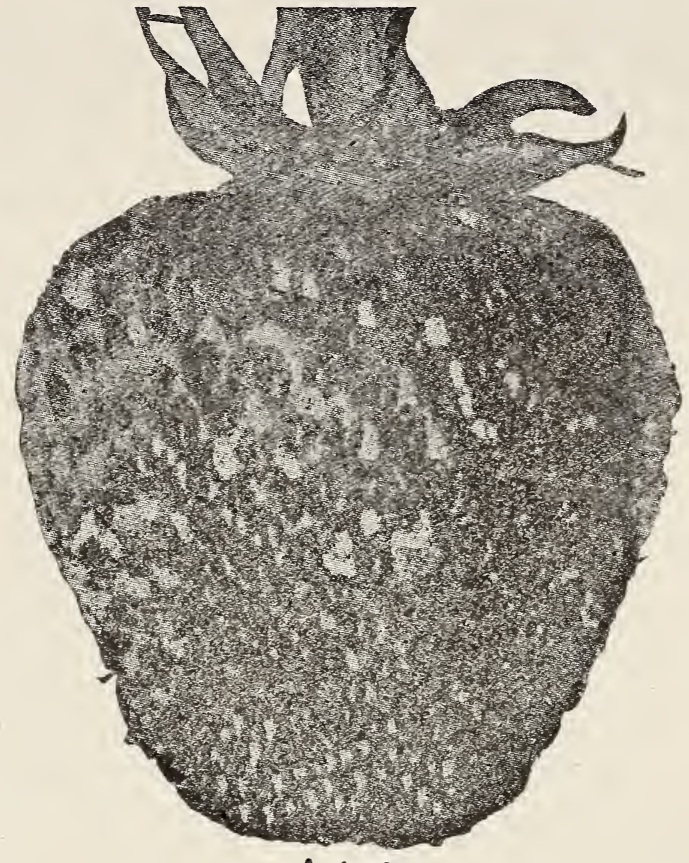

Aroma

Aroma - Large; dark red; uniformly roundish, heart-shaped; flesh firm and of very good quality. Stands shipping well; plants vigorous and very productive; blossoms rich in pollen and is good fertilizer for imperfect varieties. Late.

Bederwood-Medium size; light scarlet; rather roundish; flesh red, quality excellent. Recommended for dessert and market. Perfect.

Brandywine-Very large; crimson; flesh firm and of a peculiarly pleasing flavor; popular on the market. Plants require strong and high culture to get satisfactory results. Perfect. Medium late.

Bubach-Very large; scarlet; flesh moderately firm and of good quality, red clear through. Grown as a market variety all over the country. Vines yield well and are reliable. Imperfect. Midseason.

Corsican-Fruit large, longish heart shaped, good quality; stands shipment well. A good variety. Perfect. Midseason.

Crescent-Medium size; light scarlet: flesh fairly firm and of very good quality. Especially desirable for market. Plant strong grower and can be relied upon for crop. Especially desirable for sandy soil; overcrowds on rich. Imperfect. Midseason.

Dunlap - Medium size; dark. glossy red with golden seeds; flesh reasonably firm red and of excellent flavor. Highly recommended for all purposes. Productive and hardy. Midseason

Gandy-Large, $\quad$ i g h t crimson; flesh of firm good quality. Plants vigorous but should be planted on swamp or moist clay soils. Perfect. Late.

Glen Mary-Very large; crimson with prominent seeds; flesh firm and juicy. Recommended for dessert and market; of the very best quality. Plants strong and vigorous, thriving on all kinds of soils. Perfect. MFidseason.

Inaverland-Large, scarlet or crimson. Plant vigorous grower; resists frosts well and yields good crops. Perfect. Midseason.

Minnesota 303-Large dark red berry. Conical shape, firm and fine flavor. Plants hardy and very productive. It is a very heavy bearer of good size, much larger than the Dunlap. It is one of the best for home use or market

Sample-Late. Large size, excellent quality bright red, very firm, rich. A standard shipping variety; also fine for home use. F'ruit of uniform size. Imperfect.

Steven's Iate-Large and fine; resembles Gandy; firm and of good quality. Good late variety for market. Perfect.

Wm. Belt-Large and handsome fruit; bright red, dotted with golden yellow seeds; unsurpassed for table use. Perfect. Midseason.

\section{Everbearing Strawberries}

Progressive-This new fall bearing variety is a very good one. The new runner plants produce a nice lot of berries of good quality. The berries are not so large as Superb and not so good quality, but they yield well. The fruit of the Progressive is of good size, smooth, of good color and appearance.

Superb-Very large, dark red and glossy; fine quality. It begins to bear in Juni with immense crops and continues until late in fall. It is one of the heaviest bearers of berries in June as well as a remarkable fall bearer. Will produce a fair crop of fruit the first summer.

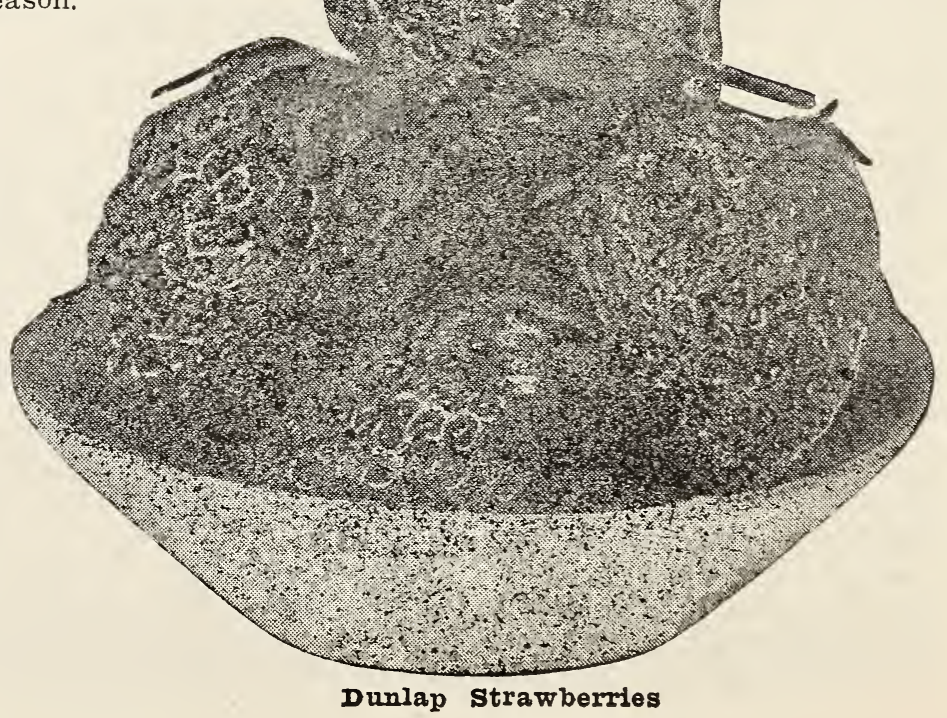




\section{DEGIDUOUS TREES}

The planting of well selected trees is a duty each land owner owes to himself and posterity, and a duty which should not be delayed, the sooner planted the longer both yourself and the public may enjoy them.

There are several good reasons for planting shade trees; they keep off the intense heat of the summer sun; they afford a cool spot where the children can play: they make the place more pleasing and they greatly increase the value of the home.

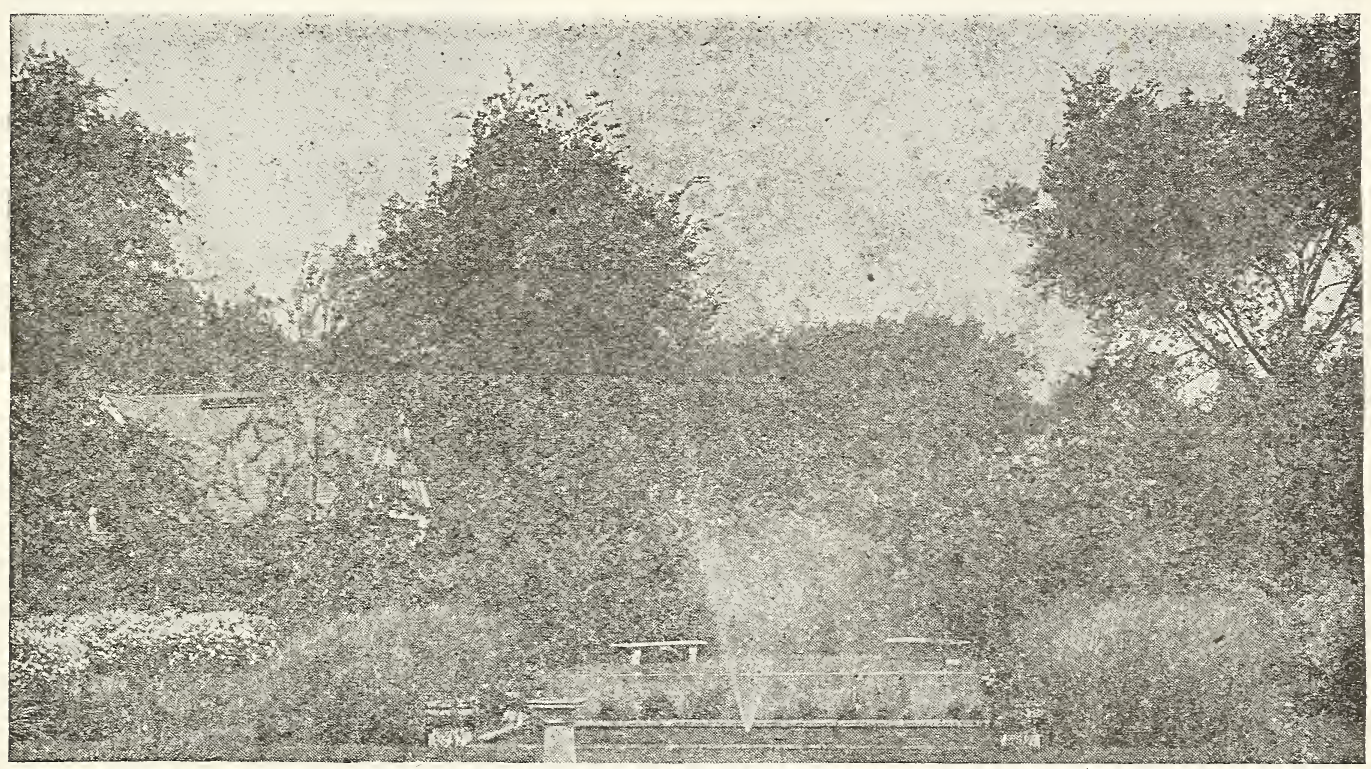

\section{NUT TREES}

\section{ALMONDS}

Irard shell-The tree is very showy when in bloom. The kernels of the nuts are large, plump and sweet. Hardy.

Soft, or Paper Shell-Encloses as fine a nut in a soft shell. Needs protection.

\section{CHESTNUTS}

American sweet-The nuts of this tree form quite an item in our commerce. Although smaller than some other sorts they are sweeter and more delicately flavored. This Chestnut is also a grand timber and ornamental shade tree, spreading, in midsummer, billowy masses of creamy fragrant catkins above its large, deep green leaves, making a most beautiful specimen on the lawn.

Paragon (Great American)-The most widely planted and most uniformly successful variety yet cultivated in the United States. The three or more broad thick, handsome nuts in each burr are of extra size and quality.

\section{FILBERTS-HAZELNUTS}

The filbert succeeds well on almost all soils, the little trees or bushes bearing early and abundantly.

Inglish-Most hardy and generally satisfactory over a wide territory. The nuts are nearly round, rich-flavored and toothsome.

\section{HICKORY}

Shellbark-In flavor and quality of kernel this is generally esteemed the choicest of our native nuts - of all nuts some experts have said. The tree is a handsome stately shade tree with tough white wood of great strength and elasticity, marketable at high prices.

\section{WALNUTS}

American Black-The large, oily nuts are borne in heavy crops. They are much relished by children, and always marketable at a fair price. The tree grows quite fast; its dark rich wood is exceedingly valuable.

Fnglish-A fine, lofty-growing tree, with handsome, spreading head; produces large crops, of thinshelled, delicious nuts which are always in demand at good prices. Not hardy enough for general culture north.

Siebold's Japan-Of the finer imported Walnuts this is the species best adapted by its hardy, vigorous habit for general culture in our country. It grows with great vigor, assuming a handsome shape without pruning, and has withstood a temperature of 21 degrees below zero without injury. Its nuts are considerably larger than the common hickory-nut, and are borne in clusters of fifteen to twenty. The shell is a little thicker than that of the English Walnut, which it resembles in a general way; the kernels are meaty, delicate, and can be removed entire. The trees begin to bear when two or three years old. 


\section{AILANTHUS-TREE OF HEAVEN}

A. Glandulosa-From Japan; a lofty, rapid growing tree, with long, elegant, feathery foliage; free from all diseases and insects. One of the most distince of ornamental trees.

\section{ALDER-ALNUS}

European or Black-A vigorous and rapid growing tree, leaves dull, dark green, turning to yellow in autumn. Of great value for planting in cold, damp ground.

Smooth (A. Rugosa)-A small tree; very valuable for planting in low, damp ground or along a water side. Flowers in late winter or early spring.

\section{ASH-FRAXINUS}

White (F. Americana)-A well known native tree; very straight. with broad, round head and dense foliage that is dark green above and light silvery beneath, fading to golden yellow. A beautiful and desirable shade tree.

Flowering Ash (F. Ornus)-A small tree producing white flowers in May or June; dark green, wavy, elliptical leaflets with downy hairs beneath; young branches purple, dotted yellow. Very showy.

\section{BEECH-FÄGUS}

American (F. Americana)-A large, stately tree with smooth, gray bark and a compact, round head. Grows very high and is one of the handsomest for street or

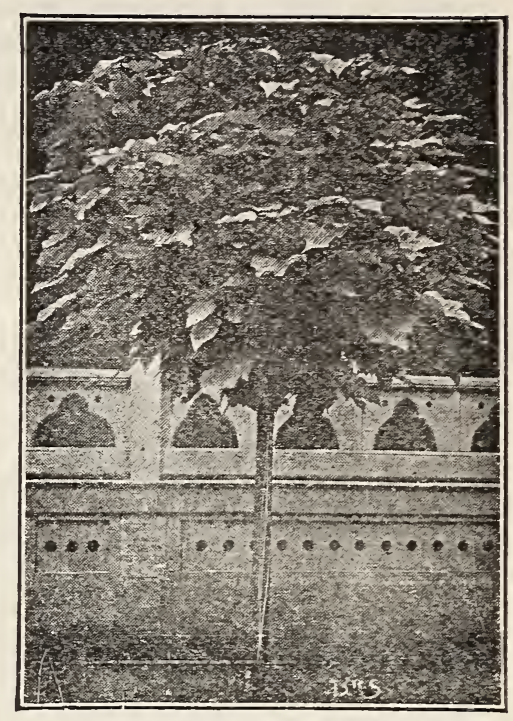

Catalpa Bungei

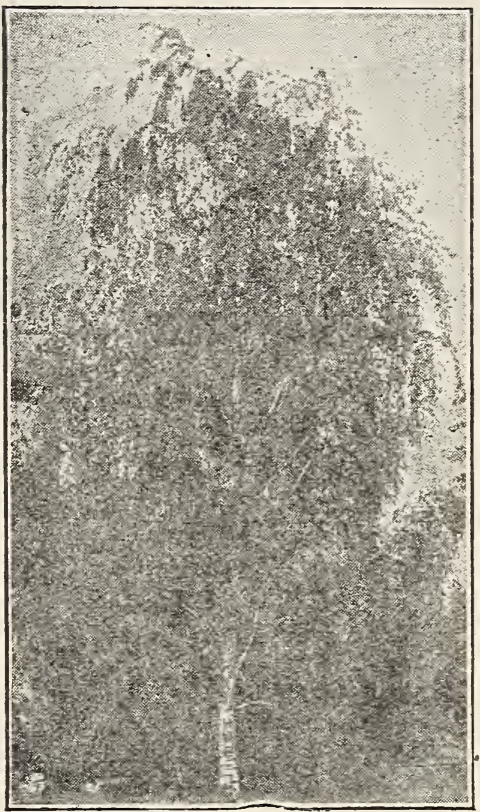

White Birch lawn.

European (F. Sylvatica)-A large and beautiful tree, with dark green, glossy leaves. Rather more compact and of slower growth than the American. A grand lawn tree.

\section{BIRCH-BETULA}

Furopean White (Betula Alba)-A beautiful tree with white bark and in age spreading and pendulous branches. Very effective for landscape.

Purple Ieaved (B. Atropurpurea)-A vigorous tree with purple leaves contrasting strongly with the beautiful white bark.

\section{CATALPA}

Chinese (C. Bungei)-A remarkable dense round headed bush, grafted upon straight, upright stem. Very hardy and effective for lawns or formal gardens.

Hardy (C. Speciosa) - A variety that is being grown in the west for timber as well as posts and shade. Has broad deep green leaves and beautiful large blossoms, making it highly ornamental for lawns or street. Rapid grower.

\section{CHERRY-CERASUS}

Double White rlowering-A small tree of garden origin, with double white flowers in great profusion. More beautiful and lasting than the common cherry. Of great service as cut flowers.

\section{CHESTNUT, HORSE-AESCULUS}

\section{Common or White} Flowering-A handsome tree of regular form with a showy foliage and covered in the spring with panicles of white showy flowers marked with red. As a lawn or shade tree it has no superior.

Ohio Buckeye (A. Glabra)-A native of Ohio, forming a large size tree, leaves light green above and darker beneath, turning yellow in autumn; flowers in large clusters; nut husk is thickly covered with spines.

\section{THE FLOWERING CRAB-MALUS}

Flowering Crab (M. Floribunda)-A small tree, native of Japan; leaves bright green and lustrous, fading with tones of yellow and bronze; flowers rose red, produced in great abundance; fruit about the size of a pea.

Bechtel's Double Flowering Crab (M. Angustifolia) - Tree of medium size covered in the early spring with large beautiful and fragrant flowers of a delicate pink color. One of the finest trees in cultivation.

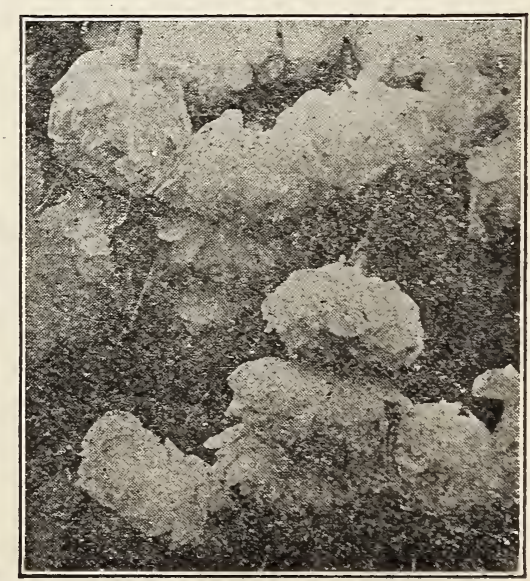

Flowering Cherry 


\section{ELM-ULMUS}

American-A magnificent tree growing 80 to 100 feet high, with drooping, spreading branches. One of the fast growing and grand native trees for lawn or street.

Fnglish (U. Campestris) - A large tree with spreading branches, forming a round-topped crown; leaves deep green and hold their color late.

\section{LARCH-LARIX}

American or ramarack-A tall, slender tree that is best at home on wet or damp soil; leaves pale green in tufts, fading and falling in autumn. Cones globular, two-thirds of an inch long.

\section{LINDEN-TILIA}

American or Basswood (Tilia Americana)-A large tree forming a broad, round-topped crown. Leaves broadly oval, dark green on top and light beneath, turning yellow in autumn; creamy flowers in summer, and very attractive to the honey bee. A grand tree everywhere.

European (L. Europea) -A native of the Alps with a conical head; is esteemed as a timber variety as well as a graceful landscape and park tree. Only suitable for well drained soils as wet, heavy soils do not insure good growth.

\section{HACKBERRY -} CELTIS

American Nettle Tree-A handsome tree with s to ut spreading branches, forming a round - topped crown, leaves almost $1 \mathrm{ike}$ th $\theta$ apple, but more pointed. Fruit resembles a small blackberry. Very desirable for street planting.

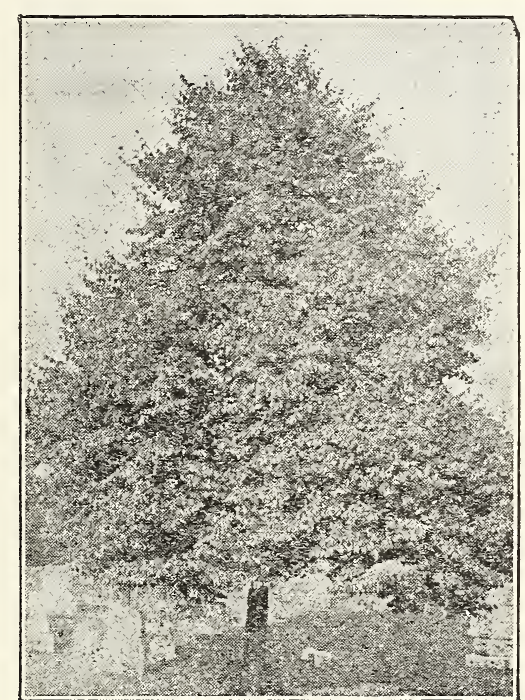

American Iinden

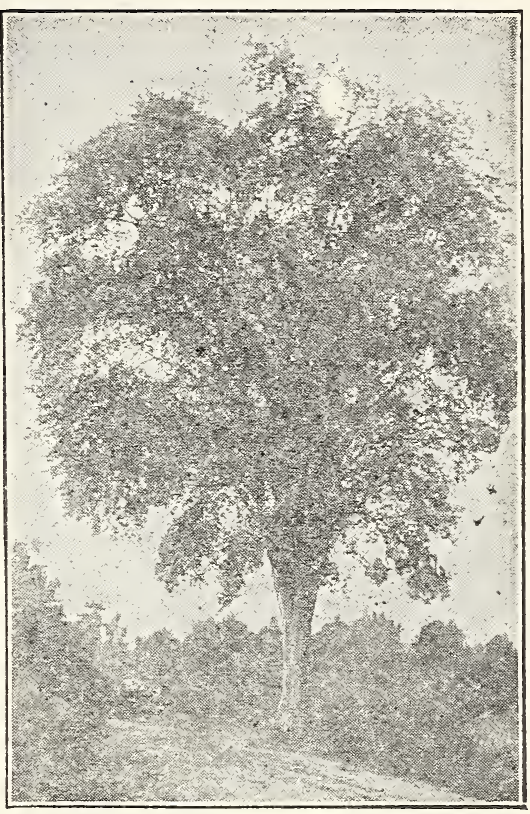

American EIm

ITentucky Coffee Tree (Gymnocladus)-A very ornamental tree of upright, and rapid growth, with rough bark and coarse branches; foliage bluishgreen; flowers white followed by long pods which hang on the tree all winter.

\section{KOELREUTERIA}

Varnish Tree-A small, hardy tree with a round head and long panicles of showy vellow flowers the end of July. Grows twentyfive to thirty feet tall. Leaves bright green, fading to yellow and bronze in the fall. Makes a rather pretty lawn tree.

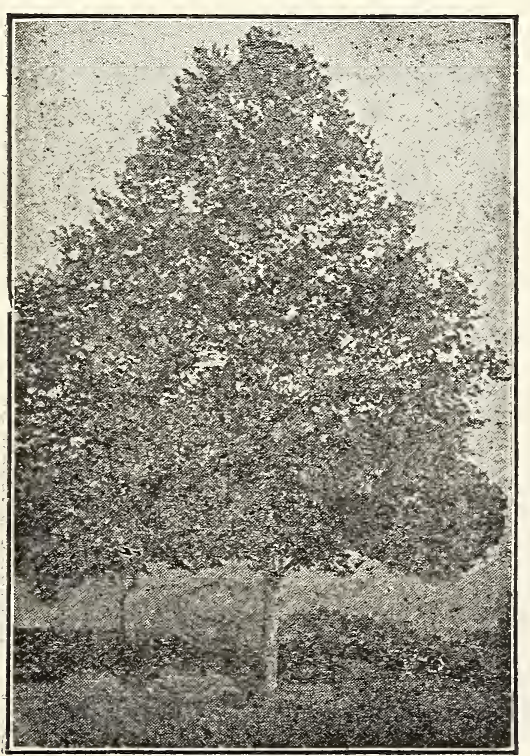

Sycamore

\section{LOCUST-GLEDITSCHIA}

Ioney Iocust (G. Triacanthos)-A rapid growing native tree with powerful spines and delicate foliage, the greenish flowers which appear in early summer are followed by flat pods eight or ten inches long. Used extensively for hedges as well as an ornamental.

\section{LOCUST-ROBINA}

Black Iocust (R. Pseudacacia) - A rapidly growing tree that reaches a large size and is valuable for timber as well as an ornamental. Flowers which appear in June are yellowish-white and very fragrant.

\section{MAGNOLIA}

Cucumber Tree-A splendid pyramidal tree that grows to a great height, flowers yellowish-white, and fruit resembles a cucumber. A most valuable hardy shade tree.

Sweet or White Bay (M. Glauca)-Slender tree or yery large shrub. Leaves oblong, shining green flowers, large, creamy white. fragrant.

\section{MAIDEN HAIR TREE-GINKGO}

G. Biloba (Salisburia adiantifolia)-A remarkable tree of spreading growth in age. Deep green. thick leaves similar in shape to those of the maidenhair fern. Rapid grower and very hardy. As a specimen or avenue tree it excels, having a very picturesque outline and retaining its leaves until very late autumn. 


\section{MAPLE-ACER}

Boz Elder or Ash reaved Iraple (A. Negundo)-A rapidly growing tree with spreading branches. Frequently planted as an ornamental, but especially popular as a wind break or for timber because very hardy, withstanding cold and drought.

Norway Iraple (A. Platanoides)-A very handsome tree attaining large proportions, its spreading branches form a dense, round head and is especially desirable for street or lawn planting. Has five lobe leaves, bright green, lighter underneath, and smooth on both surfaces, fading to yellow and gold.

Schwedleri (A. Plantanoides)-A beautiful variety with very large bronze red leaves and young shoots of the same color; a vigorous grower and most effective ornamental tree; fifty feet high.

Soft or Silver Teaved (A. Dasycarpum) - A rapid growing tree of large size, irregular rounded form; foliage bright green; for streets and parks; attains about the same height as Norway.

Sugar or Fard (A. Saccharum)-A well known native tree, valuable for the production of sugar and wood; very desirable as an ornamental shade tree.

Weir's Cut Ireaved (A. Lacinatum) -A variety of silver-leafed and one of the most beautiful, with cut or dissected foliage; rapid growth, shoots slender and drooping; ranks among the best as an attractive lawn or shade tree.

\section{MOUNTAIN ASH-SORBUS}

American-A small tree with spreading branches, forming a round crown; leaves dark green turning yellow in autumn, flowers white and flat cymes, followed later by

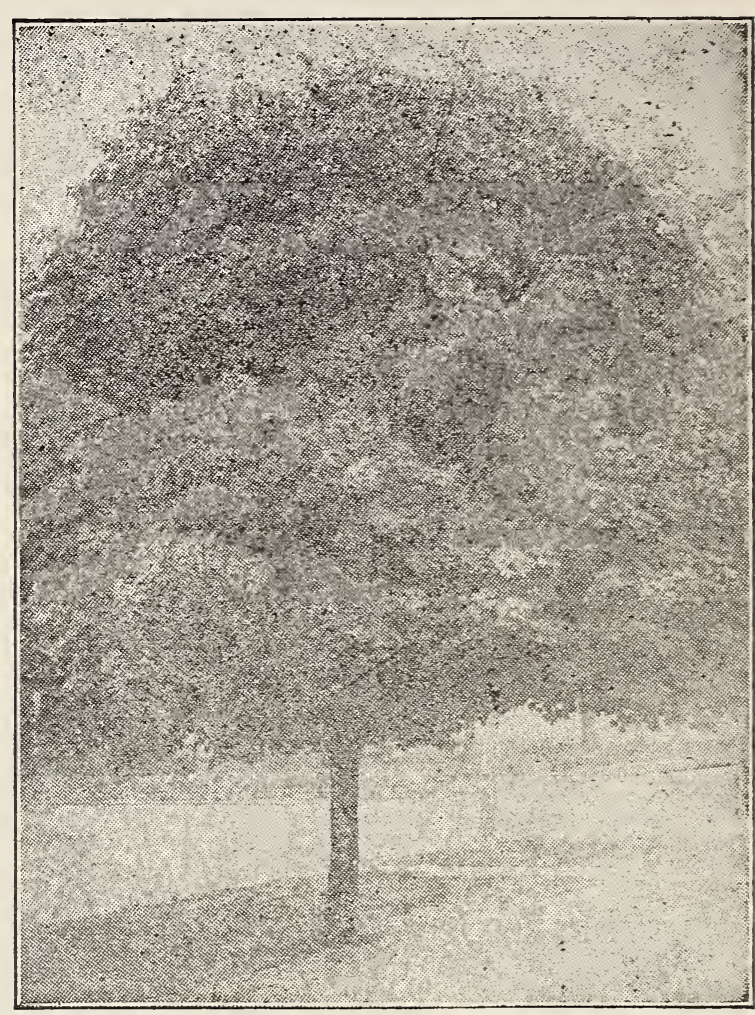

Norway Maple

showy clusters of bright scarlet berries. Especially adapted to the northern regions.

suropean-A fine tree with dense and regular head; covered from midsummer to winter with great clusters of bright scarlet berries.

\section{OAKS-QUERCUS}

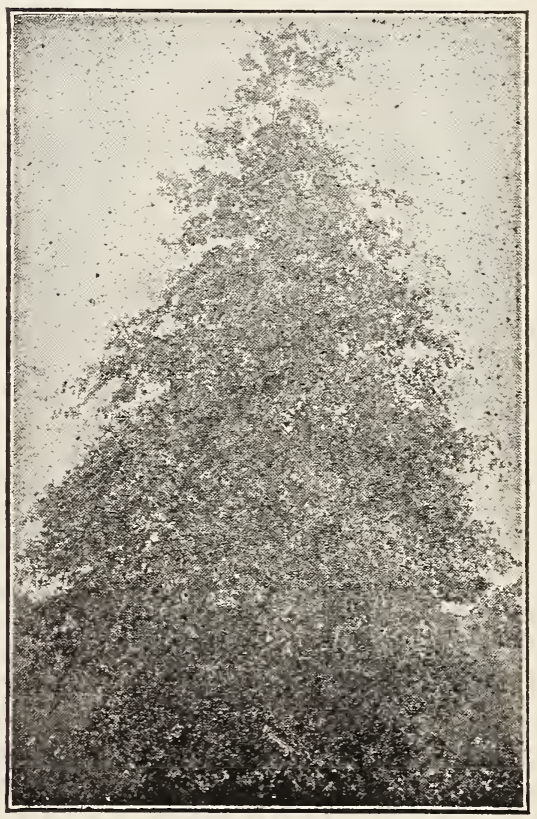

Pin Oak
White-The grandest of this genus of our American trees. A spreading. towering specie, growing one hundred feet high when fully developed with rugged, massive trunk and branches. The deeply lobed leaves change to dark crimson in the fall. This is the typical Oak tree, and where given room to develop, makes a most imposing spectacle on the lawn.

Pin (Q. Palustris) - A magnificent tree for lawn and street planting. Deep green foliage which changes to a bright scarlet and yellow by autumn; a most shapely and graceful tree, assuming the drooping habit with age.

Red (Q. Rubra) - Makes a tree of great height, eighty to one hundred feet; of large size and rapid growth; leaves dark dull green turning to orange and brown in the autumn; acorns very large; a beautiful tree for park or street.

\section{POPLAR-POPULUS}

Bolleana (Bolleana)-Grows 60 to 80 feet. Similar in habit to Lombardy; very emphatic and distinct looking tree; has silvery. white foliage.

Balm of Gilead (P. Balsamifera Candicans)-A strong growing spreading native tree; esteemed for its vigor and hardiness; leaves broad and heart-shaped, green above and rusty white below; makes a good street tree and is perhaps the best of the poplars for shade.

Carolina (P. Monilifera)-Pyramidal in form and vigorous in growth; leaves large, glossy, 
pale to deep green; valuable for street planting on account of its rapid growth.

Iombardy (P. Fastigiata)-Attains a height of from one hundred to one hundred and fifty feet; well known for its erect rapid growth and tall, spiry form; indispensable tree for landscape gardening or to break the monotony of most other trees.

\section{REDBUD-CERCIS}

Judas Tree - A medium sized tree with large irregular head shaped leaves; derives its name, Red Bud, from the profusion of delicate reddish-pink blossoms with which it is covered in early spring before the foliage appears. One of the finest of the ornamental trees.

\section{PERSIMMONS-DIOSPYROS}

Persimmons (D. Virginiana)-A native variety with round top and spreading; foliage dark green and very dense; fruit over an inch in diameter, pale orange yel-

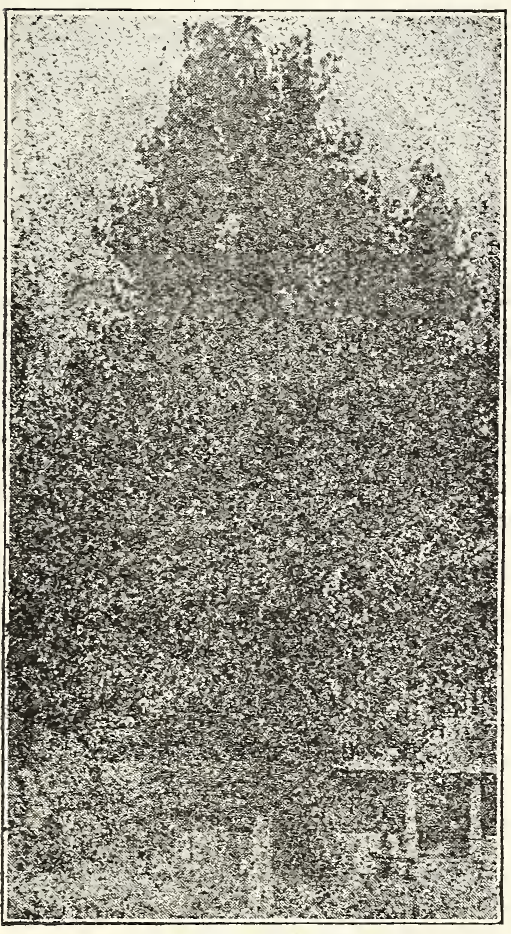
low, with whitish bloom; a beautiful lawn tree. Valuable for ornamental purposes as well as fruit. Succeeds where the Japanese varieties fail. Can be grown wherever peaches will thrive.

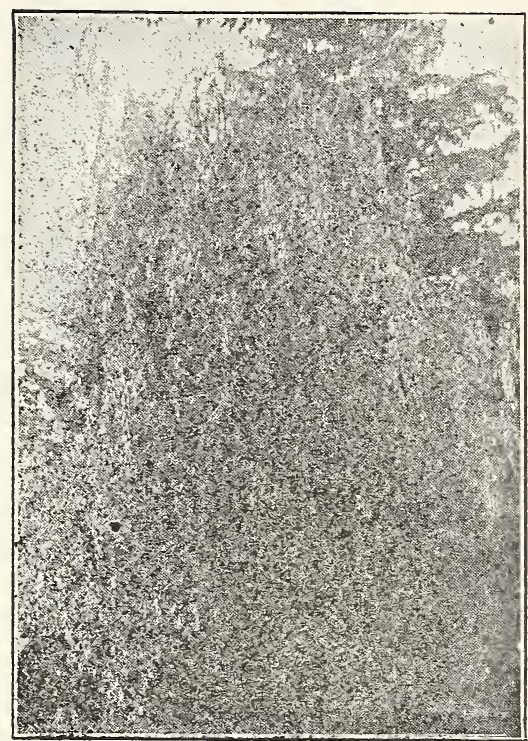

Weeping Willow

\section{SYCAMORE-PLATANUA}

American sycamore or Plane (P. Occidentalis)-A well known tree very common throughout the United States: leaves heart-shaped with small lobes, sharp pointed; branches wide and spreading; a rapid growing and beautiful tree with picturesque white or grey bark.

European Sycamore or Plane (P. Orientalis)-A rapid growing tree, large and massive with a roun-topped head: native of India and Europe and has been cultivated from time immemorial; bark whitened; bright green foliage; very hardy and generally preferred to the American for lawns and street.

\section{THORN-CRATAEGUS}

Double White Nhorn (C. Oxyacantha var. Alba Flore Pleno) - A small tree with spreadin $\mathrm{g} \quad \mathrm{s} \mathrm{p}$ in e $\mathrm{y}$ branches; very hardy and will thrive in a dry soil; this is the famous May thorn of English gardens and is very beautiful; double Carolina Poplar white rose blossoms cover the tree when in bloom. Makes splendid hedge plant.

\section{TULIP TREE-LIRIODENDRON}

Trlip Tree (L. Tulipfera) - A tall, pyramidal trunk rises to a great height and is clothed with a splendid foliage of large, glossy leaves: large, tulipshaped flowers are borne in the spring, greenish yellow and orange. One of the most distinguished tall trees.

\section{WILLOW-SALIX}

Iaurel Ireaved (S. Pentandra)-A medium sized tree with compact habits leaves shiny dark green and fragrant when bruised, the odor resembling the Bay tree. One of the best willows for ornamental planting.

Rosemary (S. Incana) - A shrub or small tree with a symetrical round top; does not grow over eight feet tall; leaves narrow, bright green, silvery white beneath.

Yellow (S. Vitellina)-A large tree with a bright yellow bark; forms a round head, and grows to a very large size. The conspicuous color of the bark gives it a pleasing contrast to the evergreens or other trees in the winter.

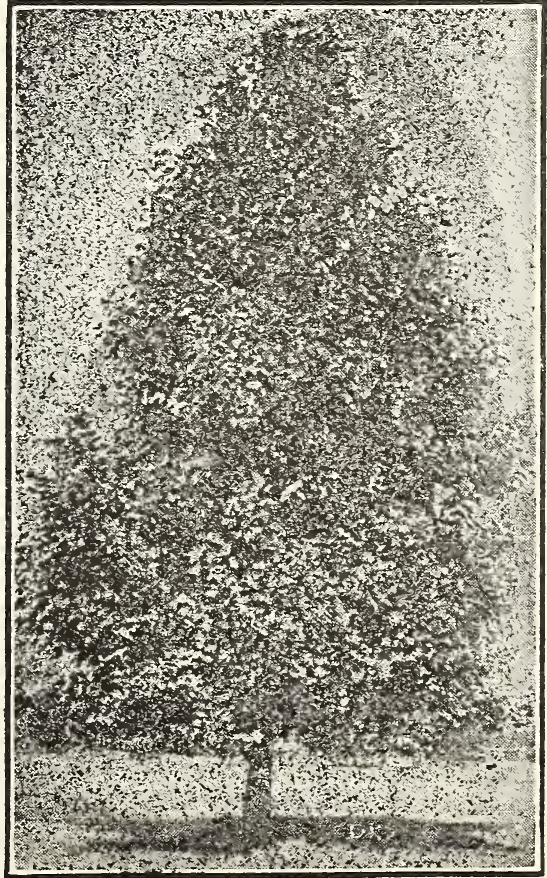

Tulip Tree 


\section{WEEPING TREES}

\section{ASH-FRAXINUS}

European Weeping-The common well known sort; one of the finest lawn and arbor trees, grows rapidly.

\section{BEECH-FAGUS}

Weeping-Native of Belyium, fine, vigorous beautiful tree. Attains great size.

\section{BIRCH-BETULA}

Cut Ieaved Weeping-Trembling, vigorous and hardy. A most beautiful tree with its leaves trembling in the lightest breeze. Its bark glistening from bright foliage and sparkling in the sun.

\section{MULBERRY - MORUS}

Tea's Weeping - A variety of the wellknown Russian mulberry. Forms a perfect umbrella-shaped head with long, slender branches which droop to the ground parallel with the stem. Very beautiful and hardy.

\section{WILLOW-SALIX}

American Weeping-A dwarf, slender variety; grafted five to six feet high; it makes one of the most ornamental of small weeping trees; very hardy.

\section{ELM-ULMUS}

Camperdown Weeping-One of the most distinct ard picturesque of all our weeping trees. Grows well in almost any climate; is of fine and notable habit, the strong branches often sweeping out horizontally several feet before they curve downward.

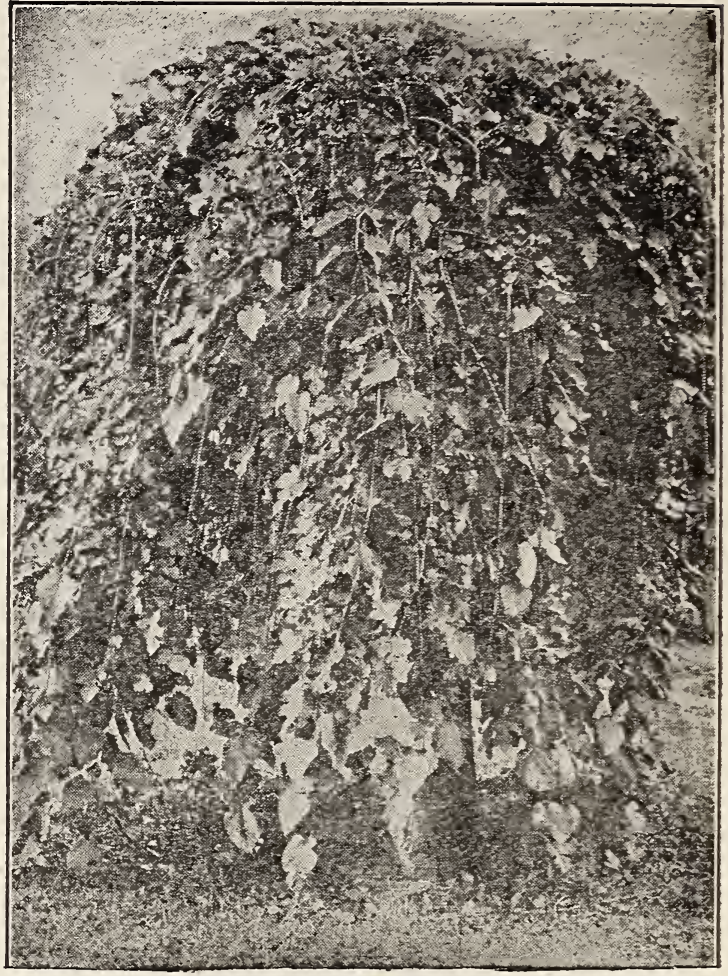

Weeping IMulberry

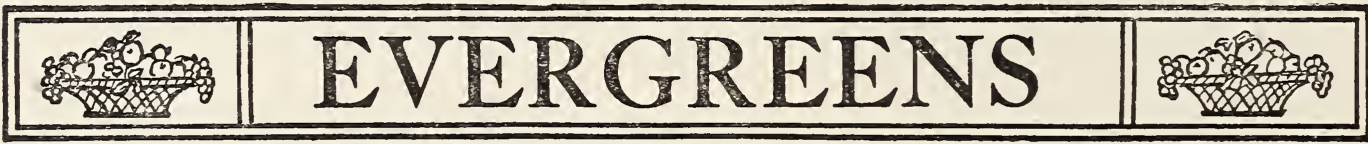

Considerable care must be exercised in transplanting everygreens and should

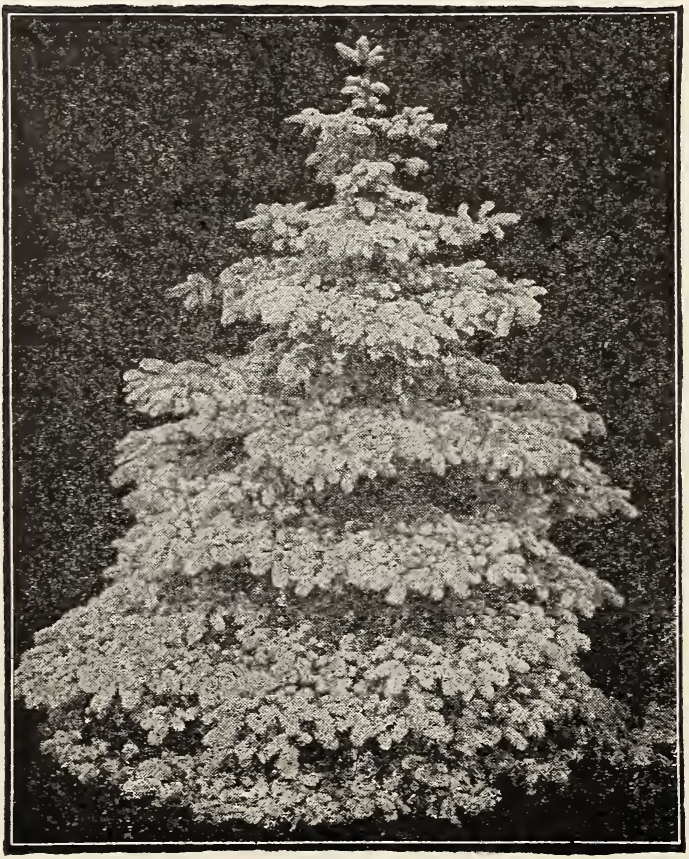

Foster's Blue Spruce never be set in the fall after the growth of other trees has ceased but their beauty and ability as wind breaks will repay the trouble.

\section{ARBORVITAE-THUYA}

American ( $T$. Occidentalis) - A beautiful native bright green; yellow-green beneath; valuable for screens and hedges.

Globe (T. Globosa)-A dense light green evergreen of dwarf habit, grows naturally found like a ball; one of the best dwarf.

Golden ( T. Orientalis Aurea)-Broad bushy grower, with deep golden foliage; ornamental.

Pyramidal ( $T$. Occidentalis, Pyramidalis)-A compact and narrow pyramidal tree; its branches are short and densely clothed with bright green foliage; very formal and attractive and the narrowest and most columnar of arborvitaes.

Siberian (T, Occidentalis Siberica) One of the best of the genus of this country; exceedingly hardy, keeping color well; growth compact and pyramidal: makes an excellent lawn tree.

\section{JUNIPER-JUNIPERUS}

Irish (J. Communis Hibernica) - A slender, columnar form with numerous upright branches; invaluable in Italian gardens and whose architectural features are desired; foliage glauceous green. 
Red Cedar (J. Virginian)-Always popular and can be used ornamentally in a number of ways thriving well and making a fine appearance in soils or situations where other trees will not grow. Eighty to 100 feet.

Blue Virginia Cedar (Glauca) - A very vigorous variety with silvery-blue foliage. This is one of the most beautiful forms of the red cedar, and makes a splendid specimen tree.

\section{PINE-PINUS}

Austrian (P. Austriaca)-A tall tree, with a broad, ovate crown; leaves in pairs, about four inches long, rigid and very dark green; cones two or three inches long. of a glossy yellowish-brown color. A fast growing, dense tree of great adaptability.

Bull (P. Ponderosa)-A lofty tree from our western coasts, growing sometimes to 150 feet. Hardy, quick growing with long needles of silvery green.

Scotch (P. Sylvestris)-Dense, broadly pyramidal, fifty to eighty feet high; luxuriant in growth, with strong, erect shoots and silvery needles.

Yellow (P. Echinata)-A tall, handsome tree with slender often perpendiculous branches, forming a broad oval crown; leaves in twos and threes, dark green, three to four inches long, dull brown. Splendid for lawn and landscape.

\section{SPRUCE-PICEA}

Colorado Blue (P. Pungens)-One of the most beautiful and hardy of all spruces; in form and habits, similar to the white spruce; foliage a rich, light bluish-green.

Douglas (A. Douglasii)-A native of Colorado; large conical form; branches are spreading, horizontal; the leaves light green above silvery white below.

Femlock (T. Canadensis)-A graceful and beautiful native tree, with drooping branches and delicate dark foliage distinct from all other trees, a handsome lawn tree and it makes an ornamental hedge.

Koster's Blue Spruce (P. Pungens, var.

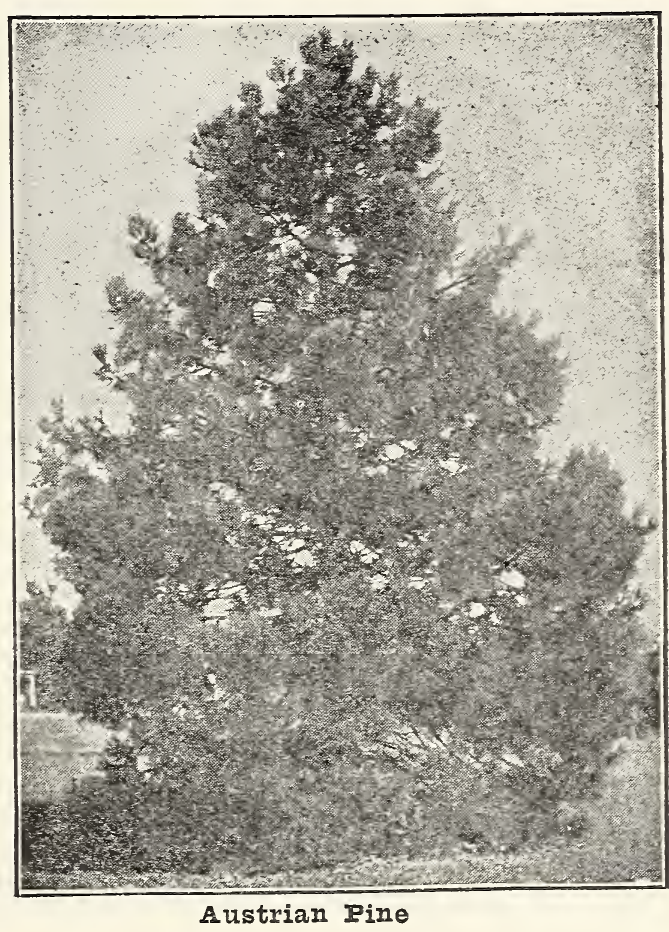

Kosteriana)-A type of the Colorado blue spruce; foliage silvery-blue, densely crowded on the many branches; very hardy.

Drarf Norway (P. Excelsa Pygmaea) - Is a low dense bush in which the branches are much shortened and crowned. A peculiar and interesting form.

Black Fills Spruce-Dark green perfectly hardy, very compact the best for general planting. It is superior to any as a windbreak. Early transplanted. A native of western South Dakota.

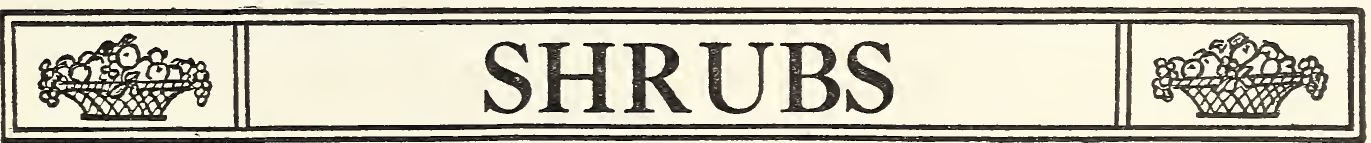

Beautiful effects are to be secured by the proper planting of hardy shrubs and we offer the most splendid selections.

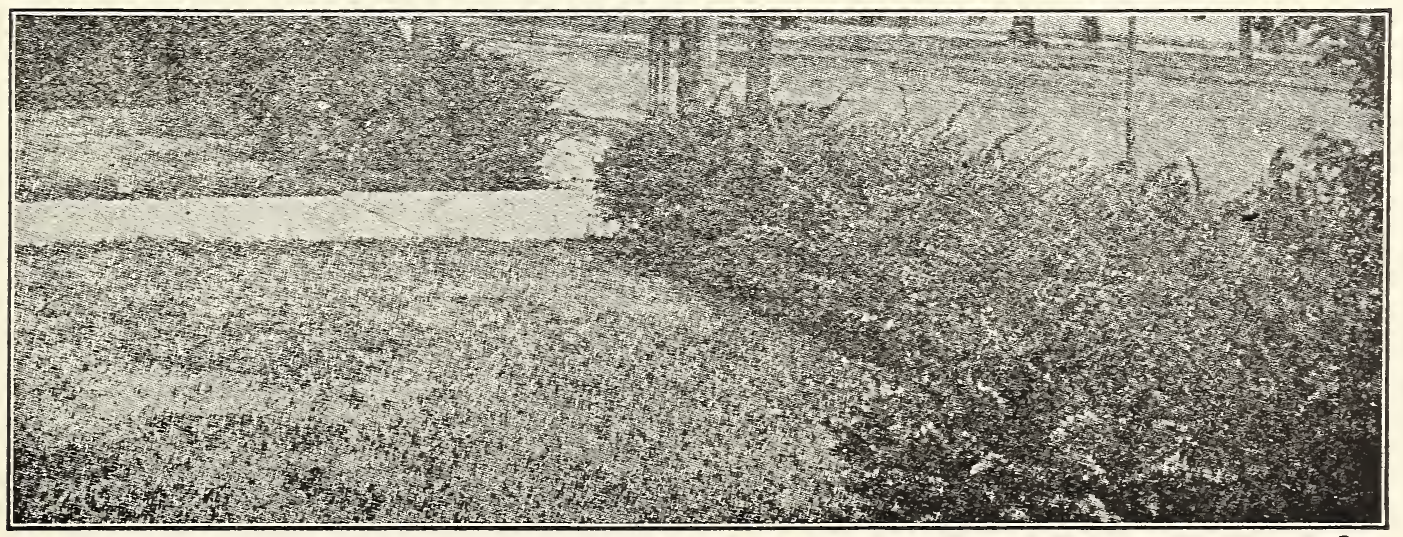




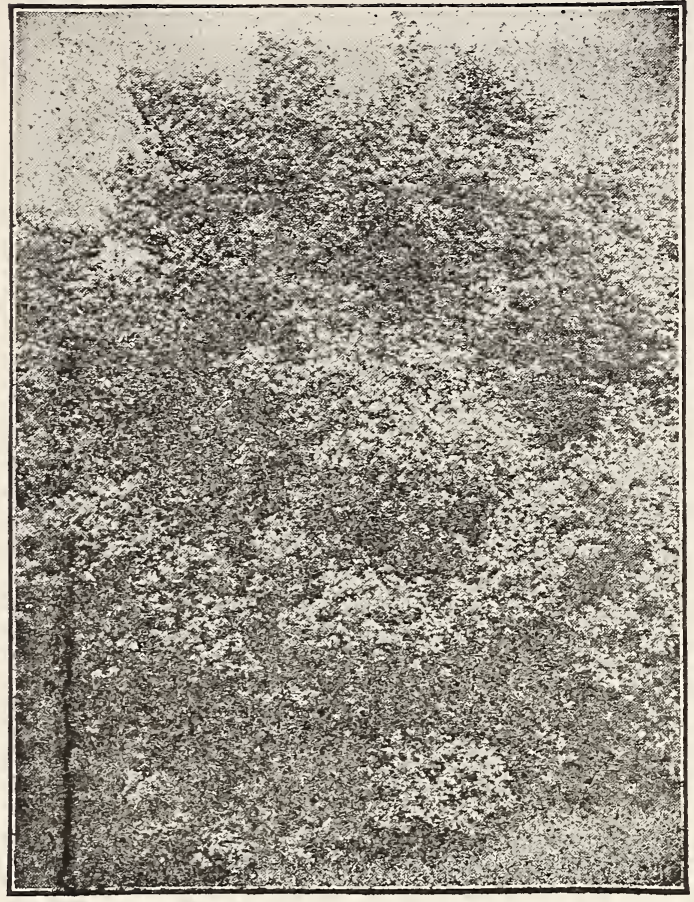

Japanese Bush Iloneysucklo

\section{AESCULUS}

Aesculas (Dwarf Horse Chestnut)-An attractive and hardy shrub which grows from 5 to 6 feet tall. Flowers grow on long spikes and make a showing.

\section{BARBERRY-H. BERBERIS}

Barberry-The barberry makes a low dense hedge which will stand any amount of trimming.

Canadian (B. Canadensts)-A native shrub which flowers in May. Handsome foliage; yellow flowers.

Japanese (B. Thunbergii) - Of dwarf habit small foliage, changing to beautiful coppery-red in the late fall.

\section{DOGWOOD-CORNUS}

European Red Dogwood (C. Sanguinea)Grows 8 to 10 feet high with purplish red branches and leaves marked with white. Blossoms in May and June are greenishwhite in flat-topped clusters, followed by bunches of black berries.

Florida (White Flowering Dogwood) Large shrub or small tree, producing a mass of large white flowers in May before the leaves appear. In the fall the deep, green foliage turns to a brilliant scarlet.

Siberian Dogwood. (C. Alba var. Siberica) -Grows 6 to 10 feet tall; dark green foliage, pale on under side. Blossoms in early summer with numerous flat-topped clusters of creamy white, followed by fruit of light blue or bluish-white. Branches blood red, very attractive shrub.

\section{CYDONIA}

Japonica (Scarlet Japan Quince)-An old well-known shrub with a profusion of bright scarlet flowers which cover the branches in early spring; small quinceshaped fruit. Makes a fine specimen for the lawn, and is also adapted for hedges. very hardy.

\section{DESMODIUM}

Sweet Pea Shrub (Pendulifrum)-A low growing shrub whose top dies down in the fall, but comes up again in the spring when it makes a valuable border, blooming in September.

\section{DEUTZIA}

Gracilis-Six to 8 feet high with numerous upright branches rough dull oreen leaves; blossoms in June with double pure white flowers in erect panicles 2 to 4 inches long.

Crenata-Similar to the preceding except that the uter row of petals are a rosy purple. Very showy.

Pride of Rochester-Six to 8 feet high, blooms in early spring with extra large. double white flowers. A distinct and valuable variety.

\section{ELAEAGNUS-OLEASTER}

Rnssian Olive (E. Angustifolia)-Eight to 12 feet high. Very hardy and prospers in almost all well-drained soils. The foliage is very handsome, willow-like and of a rich silvery white. Blossoms in June with small yellow flowers, followed by yellow fruit.

Silver Thorn (E. Longpipes)-Five to 8 feet high, of bushy habits. Foliage dark green above, with silver beneath; very showy. Blossoms in April or Meay; ar creamy white, followed by edible fruit deliclous for sauces. Fruit ripens in July.

\section{EUONYMUS}

Barning Dueh, Winged (E. Alatus)-Six to 8 feet high, with corky winged branches. Foliage bright green, fading in autumn to gorgeous tones of red and crimson.

Strawberry anh (E. Americanus)-Five to 8 feet tall. Erect with slender green branches. Follage bright green with very rose colored warty fruit.

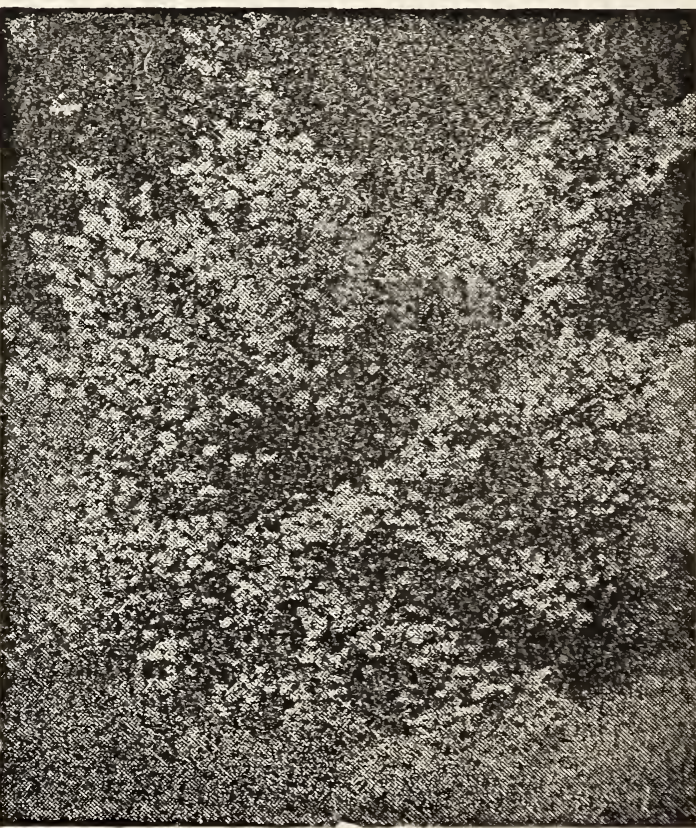

Deutzla Pride of Rochester 


\section{FORSYTHIA}

Frbrid Golden Bell-Eight to 10 feet high with slender, arching branches. Foliage lustrous dark green; blooms very early in the spring; often before the snow is off the ground. One of the most showy shrubs in cultivation.

\section{HIBISCUS SYRICACUS}

Althea, Rose of Sharon-Eight to ten feet high, resembling small flowering tree; planted closely together they make a good flowering hedge. Blossoms late in the fall. A number of colors.

\section{HYDRANGEA}

Fardy (H. Paniculata Grandiflora)-A beautiful, tall shrub; foliage of bright shiny green; .the flowers are borne in August and September in huge panicles from 8 to 12 inches long. Beautiful as a border or can be grown in tree form.

Tree Aycirangea-Tree form of the above.

Arborescens Aiba Grandiflora-Resembles the Paniculata in general form and shape of flowers; borne in panicles of pyramidal shape from 5 to 8 inches in diameter and 8 to 10 inches long. White.

\section{LILAC-SYRINGA}

Common Iilac-Up to 25 feet in height; dense panicles of flowers of the most delicious fragrance.

Double Inlac-Are more dwarf than the single flower kinds; the flowers last longer but do not bloom so profusely.

Charles $\mathrm{X}$-Rich, reddish purple flowers, luxuriant glossy foliage and a rapid grower.

Iucowig Spaeth-Flowers strikingly hand-

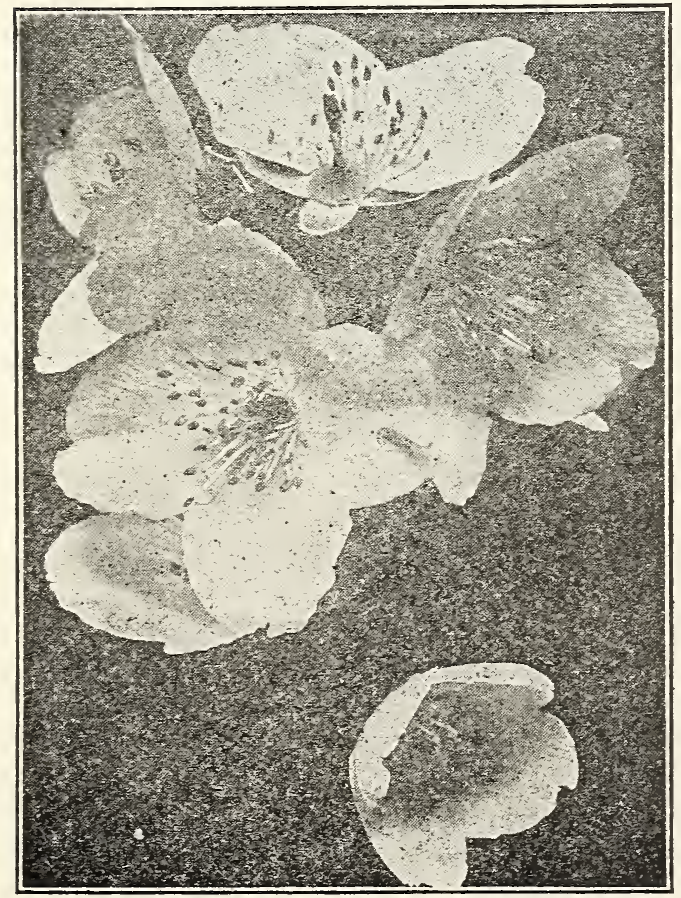

Syringa, Philadelphus or Mock Orange

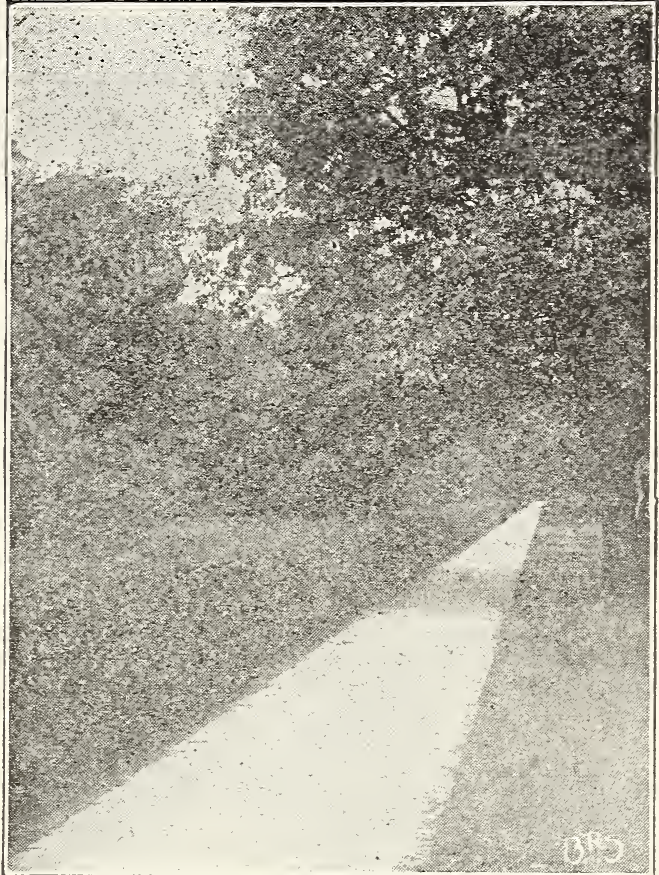

Privet IXedge

some and of enormous size. A deep rich wine color-fine.

Marie Iregraye-Beautiful creamy white flowers of enormous size, dwarf habit; one of the most popular; single.

President Grevy-A magnificent clear blue lilac, very double and large. Best of the blue sorts.

\section{LONICERA}

Fragrant Bush Foneysuckle (L. Fra grantissima)-Six to 8 feet high, with numerous spreading branches; foliage bright green; flowers white or light yellow; very fragrant.

Japanese Bush Honeysuckle (L. Morrowi)-Four to 6 feet high with spreading branches; dark green with light underside. Blooms very early in the spring.

Tartarian Honeysuckle (L. Tartarica)Eight to 10 feet high with numerous branches; bright green; blossoms in late spring with white or pink flowers.

\section{PRIVET-LIGUSTRUM}

Amoor River Privet (L. Amurense)-A valuable ornamental shrub for hedges and borders.

California Privet (L. Ovalifolium)-The well-known variety; vigorous and hardy; deep glossy green; useful for hedges and borders.

Ibota (Japanese Privet)-Large glossy, distinct foliage; fragrant white flowers produced in great profusion. Excellent hedge plant.

Polish-A compact erect growing shrub with bluish green lustrous foliage which is persistent until midwinter, and keeps its color; white flowers in panicles followed by black berries; very hardy and amenable to clipping. 


\section{RHUS}

Fragrant Sumac-Two to four feet high with branching habits; foliage bright green, fading to scarlet in autumn; blosscms in June, with yellow flowers.

Purple Fringe or Smoke Tree-Ten to 12 feet high with spreading branches; foliage green, changing to brilliant red and yellow in autumn; the blossoms take the form of very bright, mistlike flowers, having the appearance of smoke at a little distance, and last during mid-summer.

\section{RIBES}

Flowering Currant (R. Aureum)-Five to 6 feet high with upright branches; foliage lustrous green; blossoms in early spring with large and showy yellow flowers.

\section{SAMBUCUS}

American Flder (S. Canadensis) - Six to 10 feet, upright habit, the stems filled with white pith.

Golden Flder (S. Nigra Aurea)-Six to 15 feet; similar to the American except the foliage is an attractive golden color.

\section{SPIREA}

Anthony waterer-An elegant dwarf shrub, blooms all season; flowers deep crimson.

Bridal Wreath-Five to 7 feet tall; foliage glossy green, orange in autumn; blossoms cover the entire length of the graceful, arching branches.

Opulifolia (Nine-Bark, Opulaster)-Ornamental, bright foliage and double white flowers in June. Showy.

Thunbergii-Three to 5 feet high with numerous slender branches, forming a dense feathery bush. Blossoms in early spring with pure white flowers which cover it like a mantle of snow.

Van Houttei-Five to 6 feet high with numerous spreading branches; foliage upright habits; blossoms in May with lustrous green; blossoms in early spring with large and showy flowers followed by dark brown or black edible berries.

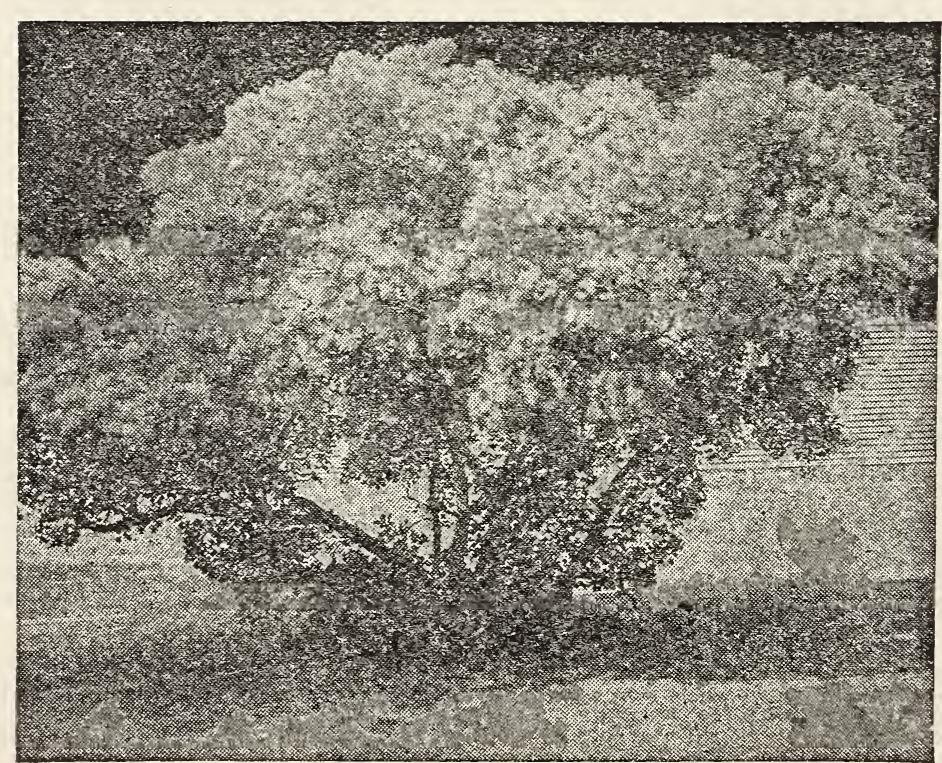

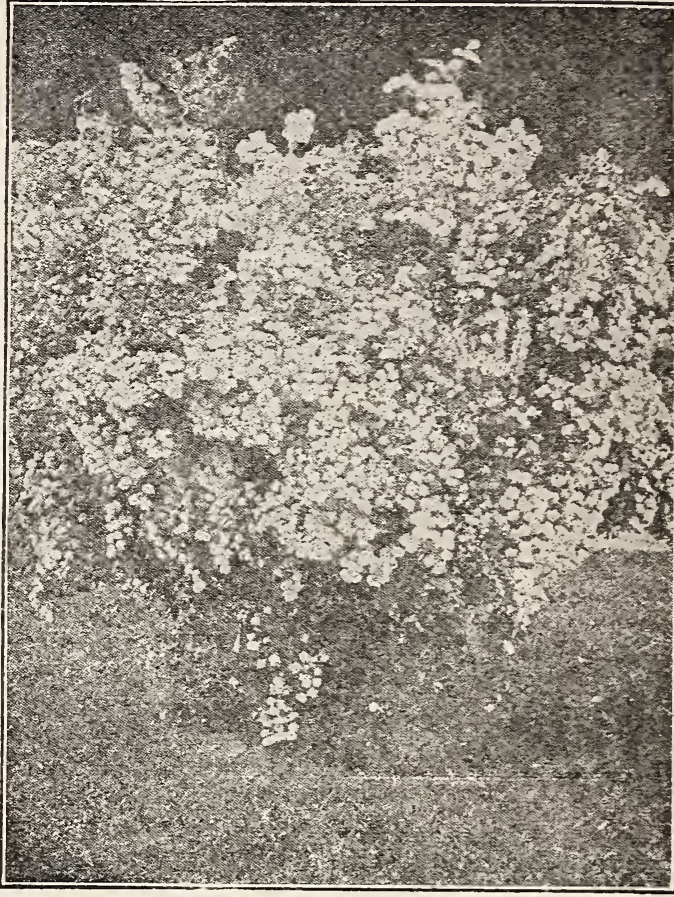

Spirea-Van Iouteii

\section{SYRINGA-PHILADELPHUS}

Common Mock Orange or Syringa-Eight to 10 feet high with upright or arching branches; foliage bright green; blossoms in May with great quantities of creamy white flowers.

Gordon's Syringa (Gordonianus)-A handsome shrub having a profusion, of white flowers in early summer.

Iemoinei Erectus-Upright grower; covered with fragrant white flowers; superb shrub.

\section{WEIGELIA-DIERVILLA} Diervilla Floribunda-Six to 8 feet
high, with numerous upright branches. Foliage dark green, blos. soms in June with brownish-crimson buds which change to bright carmine.

Rosea (D. Florida)About six feet high, with spreading habit; dark green foliage, blooming profusely with large, rose colored flowers.

Able Carrier-Rose carmine with yellow spot in throat.

Eva Rathke-Dark carmine.

Van Houttei-Clear carmine.

\section{VIBURNUM}

Common Snowball-Six to 10 feet high, numerous upright stems; blossoms in the spring with globular clusters in great profusion.

Japan Snowball-Six to 8 feet high; vigorous, with spreading branches; foliage dark green with bronze margins; blossoms in the spring. Better habits; preferred to the old variety. 


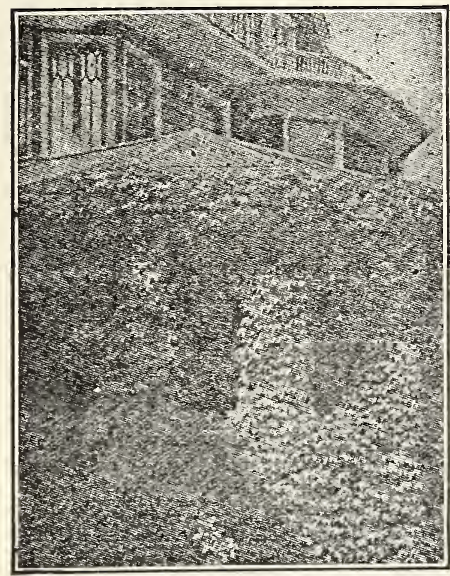

Boston Ivy

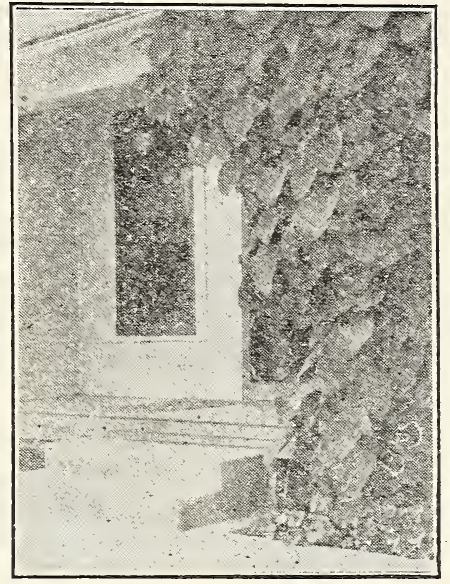

Dutchman's Pipe

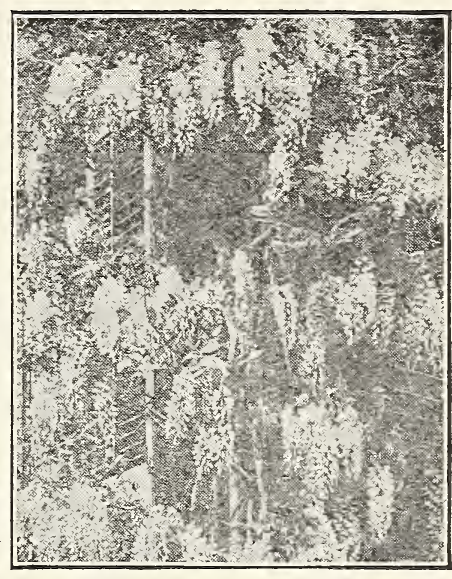

Wistaria

\section{AMPELOPSIS}

American Ivy or Virginia Creeper-The well-known native vine with five-parted leaves that change to rich crimson in autumn; berries are blue black. Very rapid grower and entirely hardy. One of the finest for covering walls, verandas or trunks of trees.

Boston Ivy (A. Veitchii)-A beautiful hardy Japanese species. Leaves overlap one another, forming a dense sheet of green. It grows rapidly and clings firmly to the smoothest surface with the tenacity of Ivy; the foliage is very handsome in summer and changes to scarlet in autumn. The most popular climbing plant for covering brick, stone or wooden walls, trees, etc.

\section{ARISTOLOCHIA}

Dutchman's Pipe (A. Sipho)-A magnificent native vine of climbing habit and rapid growth with magnificent light green foliage 10 to 12 inches in diameter and curious pipe shaped, yellowish b row $\mathrm{n}$ flowers; grows well in shade.

\section{CLEMATIS}

Sweet Scented Japan Clematis (C. Paniculata) - Flowers are pure white, medjum size, fragrant and borne in immense sheets in September. Foliage is clean and glossy of from 25 to 30 feet in a single season and should be cut back to the ground each spring.

(Cirgin's Bower remarkably rapid climbing plant, g rowing to the height of 20 feet, producing an immense profusion
flowers in August.

Henryi-Very large. creamy white, profuse bloomer.

C. Jackmanni - Intense violet-purple flowers are 4 to 6 inches in diameter when fully expanded; remarkable for its rich velvety appearance; an abundant and successive bloomer.

C. IMadame Edouard Andre-Color a distinct crimson-red. flowers very large and velvety; has been called the crimson Jackmanni.

\section{EUONYMUS}

Fvergreen Vine (E. Radicans)-One of the finest evergreen vines with small rich green foliage and pink fruits in cells which separate and expose the scarlet arils covering the seeds making a most attractive feature. It is a treasure. Used for vases, baskets

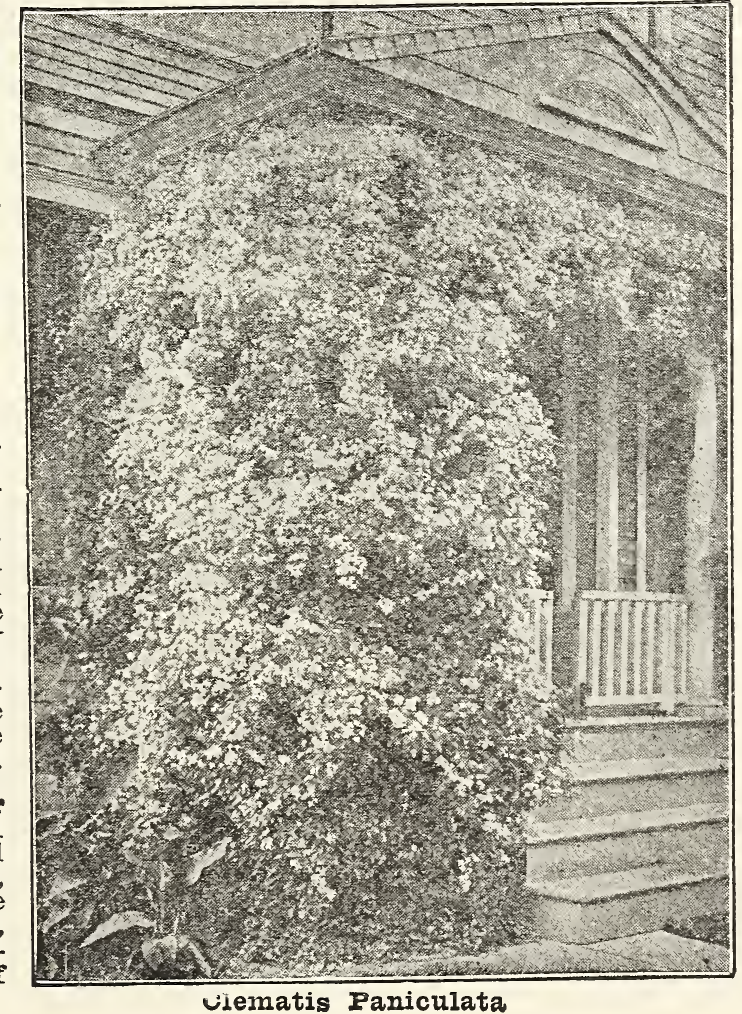
and borders of beds.

LONICERA

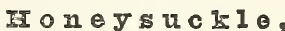
Fili's (Lonicera Halliana) - Blooms all summer, flowers yellow and white almost evergreen.

$J$ a $p$ a $G$ old en I e a ved II on e Jsuckle - A handsome and desirable variety. Fl o w ers are creamy white and form festoons and masses.

\section{WISTARIA}

Chinese Wistaria (T) Sinensis) - One of the most elegant and rapid growing of all cli m b i $\mathrm{ng}$ plants; attains an immense size growing at the rate of 15 to 20 feet in a season. Has long pend'ulous clusters of pale blue flowers in May and June, and in autum.n.

Japanese Wistaria (W. Multijuga) A Japanese species with dark blue flowers. 


\section{ROSES}

Roses thrive best in a medium light clay soil. Before planting prepare the soil by spading and thoroughly working over to a depth of about 18 inches, fill in well-rotted stable manure while spading and work it carefully into the soil. After the plants are set, for best results cut all branches back to within 3 or 4 inches of the top of the ground. The new growth coming out will make a much nicer head than if the plant were not pruned, and the bushes will bloom all the better.

\section{Hybrid Perpetuals}

American Beauty-Deep pink, shaded with carmine, large globular, delicious odor, desirable for forcing; not to be chosen for out doors growing.

Anna de Diesbach-Beautiful shade of carmine; large and showy, flowers slightly cupped particularly fine in bud. A vigorous grower. quite hardy; a good forcing rose.

zaroness Eothschild-Of light pink flowers of immense size, perfect form and exquisite color, highly scented. One of the finest exhibition varieties. very hardy and late bloomer.

Clio-Flesh color shaded in the center with rosy pink. Large, globular form. Plant is strong and blooms freely, displaying its great flowers boldly on good stems against large rich leaves.

Earl of Dufferin-Rich crimson maroon with dark velvety shadings. Flowers are large, full. globe-shaped. Thick petaled and very fragrant. Grows well and blooms freely, with many handsome buds in autumn. One of the finest dark roses.

Frau Karl Druschki-Snow white, very large, perfect form. A vigorous grower and free bloomer. Bright heavy foliage and strong upright growth; flowers borne on long fine stems.

General Jacqueminot-Brilliant velvety crimson, large and extremely exective. A famous bud and forcing rose quite as well adapted for garden culture. Very fragrant and one of the most popular sorts grown.

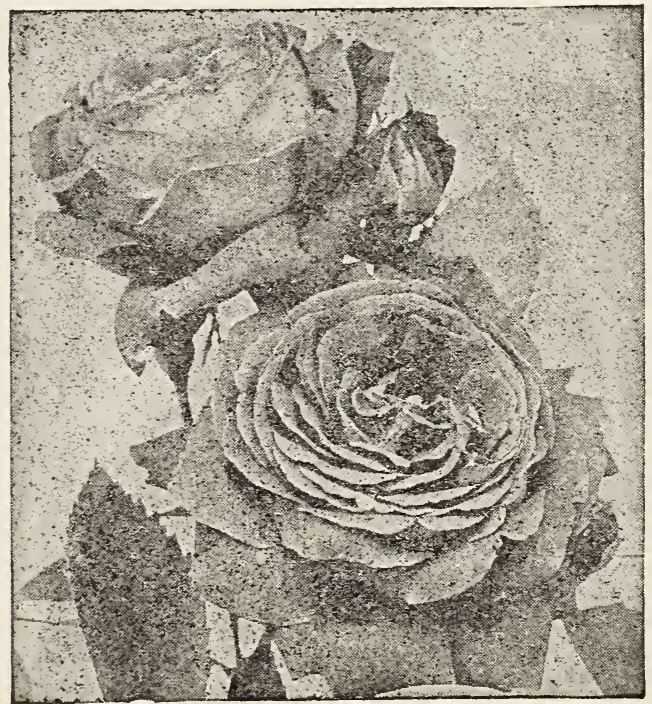

General Jacqueminot

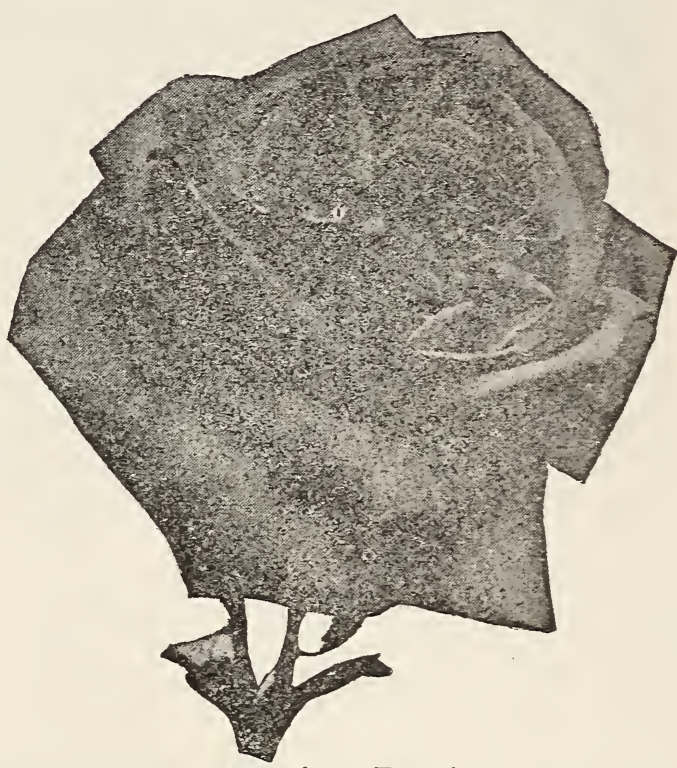

American Beauty

Hugh Dickson-Deep crimson, shaded scarlet; large; full; perfect form; petals smooth slightly cupped and reflex; very fragrant; free and continuous bloomer. One of the best autumn Roses.

Magna Charta-Clear, rosy, red beautifully flushed with violet crimson; sweet fragrance.

Margaret Dickson-A large and handsome winter rose of vigorous growth and magnjficent form; petals very large shellshaped and of great subsistance; fragrant. Foliage is large, dark green and rich. displaying the grand flowers well.

Marshall P. Wilder-Raised from the seed of Gen. Jacqueminot. Cherry color of good size, perfectly double and very fragrant. It is of vigorous growth and healthy foliage. In wood, foliage and form of flower it resembles Alfred Colomb, but excells that variety in vigor, hardiness and freedom of bloom. One of the finest of its color.

Mrs. J. H. Iraing-The color is a soft and delicate shade of pink; the flower is large. well formed, very fragrant and produced on good stems. The buds are long and pointed and extremely pretty. For outdoor planting this is one of the best roses introduced in many years. It blooms continuously in the open ground and is also valuable for forcing. the buds selling at high prices.

Paul Neyron-The largest rose in cultivation, sometimes called the peony rose color bright cerise red. Often produces 
blooms five inches in diameter. Very fragrant. The plant makes a strong, healthy growth and has clean, glossy foliage, it blooms almost without intermission from June until late October.

Ulrich Erunner-Bright cherry-red, very attractive; flowers of fine form carried well upon the plant; petals of great substance; plant hardy, vigorous, and resists mildew.

\section{Hybrid Tea Roses}

Caroline Teatout-Clear rich pink, finely edged with silvery rose. The blooms are large and handsome. resembling the famous La France.

Gruss an Teplitz-Bright scarlet, shading to velvet-crimson; fragrant; free grower and most profuse bloomer; lovely foliage. This variety is especially valuable for bedding purposes.

Kaiserin Augusta Victoria-Creamy white and sweetly fragrant; buds are large and pointed and flowers very full and large. Very hardy and continuous bloomer.

Killarney-Noted for its freedom of bloom and the large size of its intensely fragrant flowers. Buds are large long, and pointed. Color flesh, shaded white, suffused pale pink.

Iar'rance-Flowers a delicate silvery rose, often silvery pink with peach shading; very large. very double and of superb form. The sweetest and most useful of all roses; flowers continually throughout the stason and is deservedly a favorite with many rose growers.

Meteor-A rich dark, velvety-crimson, everblooming rose. Flowers are of good size, very double and perfect in shape, either as buds or when fully opened. Plant is vigorous and remarkably free-flowering. Excellent for pot culture and best of all

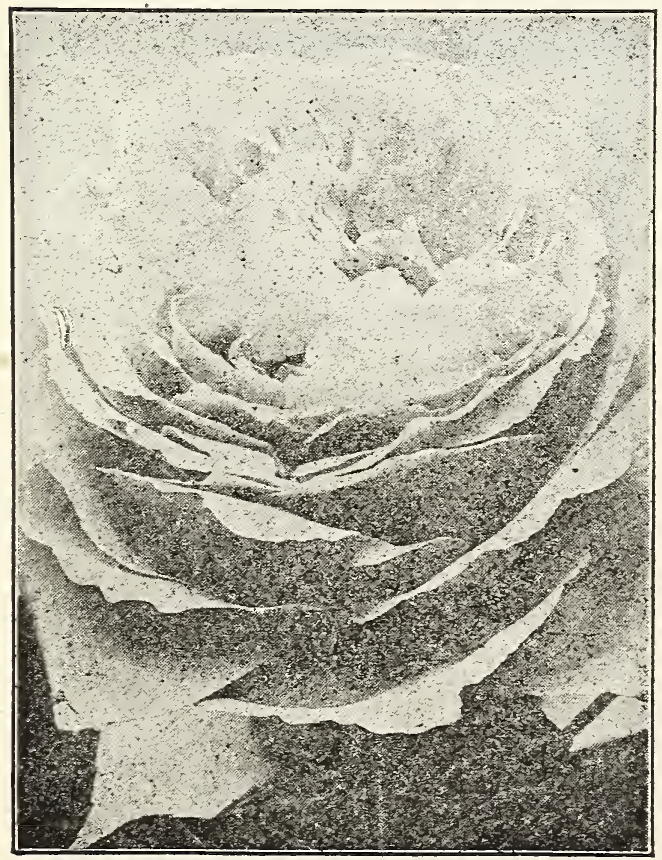

Mrs. J. F. Iaing

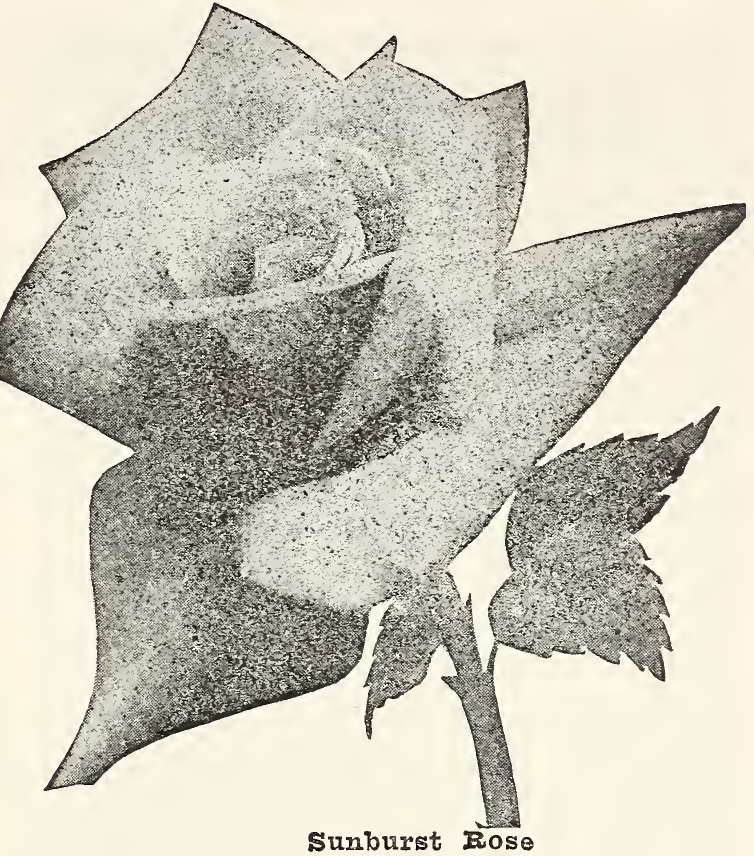

the Hybrid Teas to bed for summer cut flowers as it retains its color well even in the hottest weather.

Sunburst-Rich cadmium yellow, with orange-yellow center: magnificent freeblooming variety; vigorous grower with flowers elongated cup form.

\section{Everblooming Tea Roses}

Bridesmaid-Clear bright pink of an exquisite shade; large. full and globular, a constant bloomer. Grown chiefly for its large. solid and handsome buds; the stems are good, the foliage glossy. Excellent for bedding.

Duchess de Brabant-Salmon rose with amber shadings, a rich and peculiar color. The flowers are gracefully irregular and loose when expanded, but have elegantly pointed buds and a pervading peach fragrance. Extra vigorous and free in bloom in every way a beautiful rose.

Perle des Jardins-One of the most beautiful deep yellow roses in cultivation, varying from canary to golden yellow, in large, full. elegantly shaped buds and blossoms, very double and fragrant. A healthy free grower with beautiful foliage and unequalled in profusion of bloom.

The Bride-Most beautiful of the white Tea roses and forced in numberless quantities each year. The great solid flowers remain perfect long after cutting, the stems are long and stiff, the foliage large dark and glossy.

\section{Miscellaneous Roses}

Clothilde Soupert-Outer petals pearl white, shading to a center of rosy pink; the flowers are very double and handsomely formed. A grand free-flowering rose, fine for bedding or pot culture.

Crimson Baby Rambler-Crimson flowers in broad clusters, like those of the Crimson Flambler: a compact bush about two feet high. One of the finest bedding roses ever introduced. 


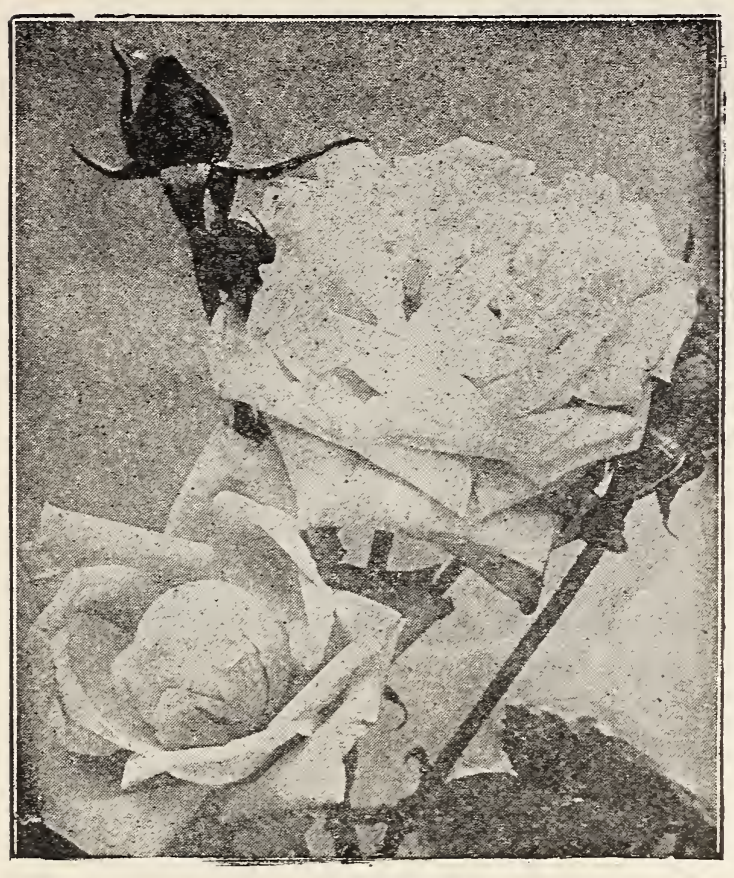

Iafrance

Pink Baby Rambler-This has all the characteristics of the Crimson. but is loaded with great clusters of bright pink roses.

\section{Rugosa Roses}

Rosa Rugosa Alba-Pure white, single, having five petals and highly scented.

Rosa Rugosa Rubra-Bright rosy crimson, single, succeeded by large, brilliant berries of much beauty.

Madam George Bruant-White and fragrant buds long and pointed, semi-double when open; borne in clusters throughout the season; vigorous and hardy.

Conrad Ferdinand Meyer-Double silvery pink flowers. large, cup-shaped; borne well above handsome Rugosa foliage. Exquisitely perfumed and perfectly hardy.

New Century-Flowers clear, flesh pink. three to four inches across, perfectly full and double. Perfume of sweet briers and is one of the most constant bloomers of its class.

\section{Moss Roses}

Admiral Dewey-Dark red, very vigorous, one of the best.

Crested Moss-Deep pink buds surroundea with a mossy fringe and crest; exquisitely fragrant.

Fenry Martin-Rich, glossy pink, tinged with crimson; large globular flowers. full, sweet and finely mossed.

Iuzemburg-Clear. deep crimson. large, very sweet and mossy.

Perpetual White-Pure white, blooms in clusters, double, beautiful. vigorous.

\section{Climbing Roses}

Baltimore Belle-Pale blush, nearly white, very double. Blooms in large clus- ters late in the season, one of the best white climbers.

Climbing American Beauty-Rosy crimson almost identical with its parent, the American Beauty, and with rare fragrance; strong habit of growth.

Marechal Neil-Beautiful canary yellow large, full, globe-shaped flowers of delightful fragrance. Free-flowering; one of the finest yellow tea-scented roses yet introduced.

Prairie Queen-Bright canary yellow, compact and globular flowers; a rapid climber; hardy and one of the best.

Seven Sisters-Crimson, changing all shades to white, flowers are borne in clusters; one of the old fashioned sorts.

Thousand Beauty Rose-A new climbing rose, producing on the same bush so many different colored flowers that it is impossible to describe the variations. hence the very fitting name. Blooming profusely from beginning of June until last of July. Colors run from tender rose to bright rose and carmine with white and yellow tints showing; a strong grower and hardy.

\section{Rambler Roses}

Crimson-The famous crimson clustered climber, so extremely effective when grown on pillars and trellis. The flowers are grown in pyramidal panicles, each carrying thirty to one hundred blooms and over; the individual flowers are from one to one and one-half inches in diameter and remain in perfect condition a long time.

Dorothy Perkins-Clear, shell-pink flowers borne in large clusters of twenty-five to thirty, sweetly scented. full and double with crinkled petals. Foliage stays on a long time.

Flower of Fairfield (Everblooming Crimson Rambler) - The name is its best description. Perfectly hardy, and blooms all summer. Has created a sensation among rose-growers everywhere.

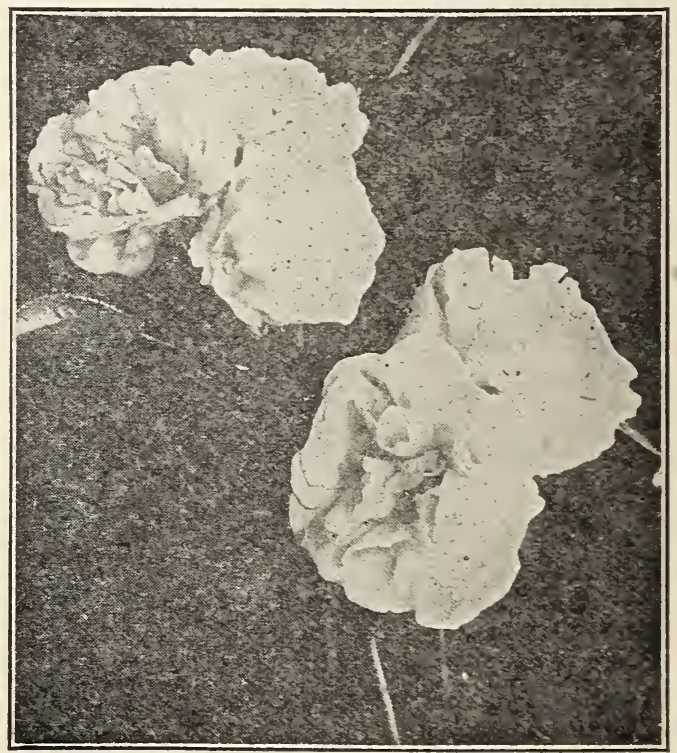

Thousand Beauties 
Philadelphia-Flowers deep rich crimson, more intense than the Crimson Rambler. with larger tresses of flowers which are perfectly double; the color does not fade and the clusters completely cover the bush. Vine is very hardy and strong grower.
Yellow Rambler-A clear decided yellow, flowers of medium size in immense clusters, very sweet scented; hardiest of all yellow climbing roses. It is a rampant grower, well established plants often making a growth of ten to twelve feet in a season.

\section{Bulbs and Roots for Spring}

Amaryllis (Jacobean Lily) - Remarkably handsome flowers; they thrive best in pots of rich loam, can also be grown in water like Hyacinths; velvety-crimson; July; $2 \mathrm{ft}$.

Begonia (Tuberous Rooted)-Handsome foliage and flowers; bright and elegant flowers of white, scarlet, yellow and pink; thrives in any good soil; good for massing; JulyAugust; 1 ft.

Caladium (Elephant's Ear)-Tropical foliage plant, effective grown as specimen plant or groups on lawn; leaves smooth, light green and very large.

\section{CANNAS}

Austria-A fine variety of the orchid-flowered type; large handsome foliage; canaryyellow blooms.

Black Beauty-Small, red bloom; rich bronze foliage. Best of all the red-leaved sorts. $6 \mathrm{ft}$.

Florence Vaughan-Flowers of the most brilliant golden yellow, dotted with brightest scarlet. $41 / 2 \mathrm{ft}$.

Iing Frumbert-Foliage is rich bronze and the flower is almost as large as the orchid Cana, often measuring 5 to 6 inches across. In color it is a glowing scarlet often streaked with gold. $3-5 \mathrm{ft}$.

Madame Crozy-Flowers crimson-scarlet and goldbordered. Three and onehalf feet high. Foliage green

Pillar of rire-The flowers are rich cardinal red and open all at once on the large truss that bears them; foliage green' $4-\hat{\imath} \mathrm{ft}$.

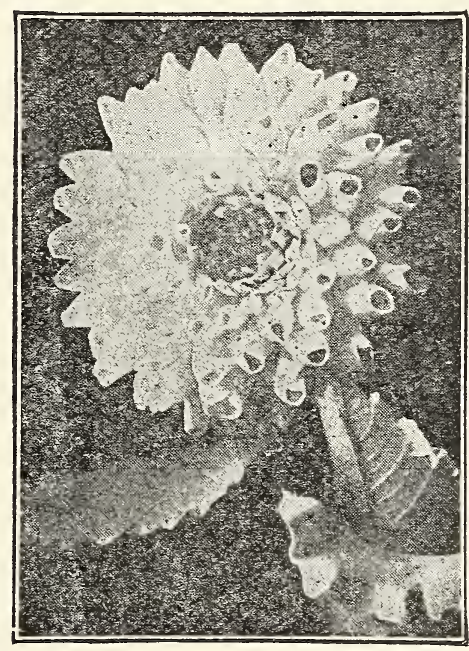

Show Dahlia

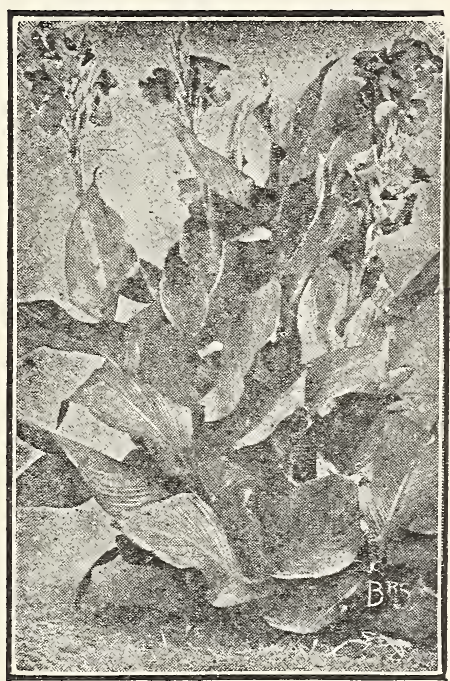

King Iumbert Canna

DAHLIAS

Decorative-Large gracefully formed flowers with broad petals; large full but open faced gorgeous display; various colored flowers; $2-4 \mathrm{ft}$.

Cactus-Long narrow pointed tubular and twisted petals; striking; various colors; $2-4 \mathrm{ft}$.

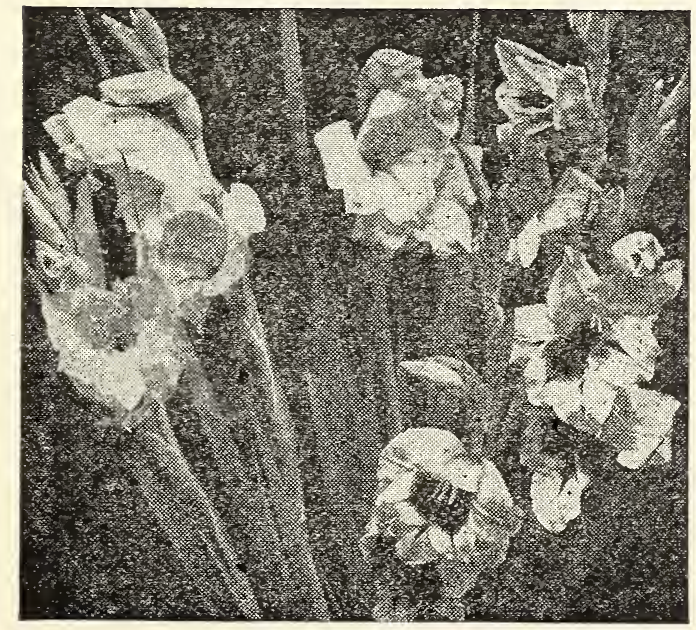

Gladiolus

Double or Show-Most formal and perfect in shape; outlasts other varieties; various colors; $2-4 \mathrm{ft}$.

Pompon-Double flowers, ball shaped.

Peony-flowered - Semi-double flowers with open center.

\section{GLADIOLUS}

Gladiolus-Beautiful as an orchid; old favorite of the home garden; finest of bulbs for spring planting; shades of white, red, yellow and blue; blooms July-frost; $2-5 \mathrm{ft}$

\section{HYACINTH}

Summer Hyacinth (Candicans)-A very stately bulbous plant with very stately Yucca-like leaves; fragrant white. bellshaped flowers in spikes; July-August; $3 \mathrm{ft}$.

\section{TUBEROSE}

Tuberose-Beautiful long, compact spikes of fragrant white. double flowers in August; $2-3 \mathrm{ft}$. 


\section{Hardy Bulbs for Fall Planting}

Chionodoxia (Glory of the Snow)-One of the earliest flowers to bloom; profuse show of blue flowers in MarchApril; 6 in.

Calla Richardia Aethiopica (Lily of the Nile)-The old favorite White Calla Lily; well-known plant of easy culture, one of our best window plants in winter.

Crocus-These are delicate and tasteful in form and varied and gay in color. Until the flowering of the Hyacinth, and through the most changeable and unpleasant of the spring weather the garden depends almost alone upon the Crocus for its brightness. Plant the bulbs in autumn about 3 inches apart and cover with 2 inches of soil. Cover in fall with a little straw or coarse manure to keep the bulbs from being thrown out by the frost.

Fyacinths-Among all the bulbs used for winter flowers the Hyacinth stands foremost. Flowers may be produced by placing the bulbs in a glass filled with water or placed in plots or boxes in soil; colors, blue, red, white with various shades. Single, double and Roman varieties.

Freesia-One of the most beautiful of all cape bulbs, with a beautiful grace of form; delightfully fragrant; valuable as cut flowers and force readily; white flowers.

Femerocallis (Yellow Day Lily)-Popular hardy tuberous plants, belonging to the lily family; they succeed everywhere; trumpet shaped flowers of yellow shades; June-August; $21 / 2-31 / 2$ ft.

Iily-of-the-Valley -One'
of the most charming of
the spring flowering plants;
graceful white chains of
fragrant flowers; prefers
deep, rich soil; does well in
shade; May; 6 inches.
Narcissus-Some varien
ties bloom as early as the
Crocus. The flowers assume
many forms and present
many charming combina-
tions of white, gold, prim-
rose, orange, sulphur and
pure yellow. Some are
quite fragrant, all very
hardy, except the clustered
Polyanthus. Double and
single; trumpet, star poet's,
poetaz and Polyanthus va-
rieties.

Iris, Spanish-Unlik e most sorts, these come in bulb form. like tulips, delicate shades of various col-

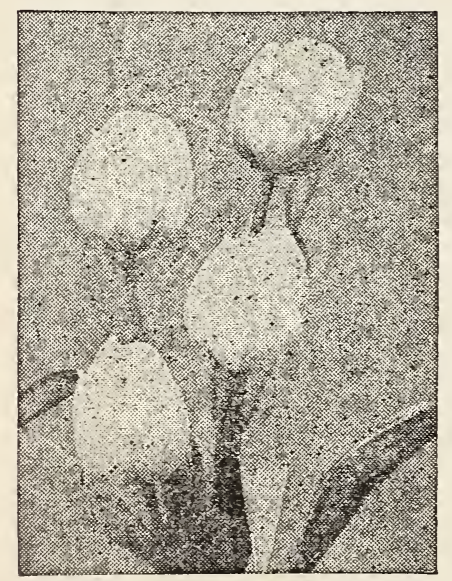

Tulips

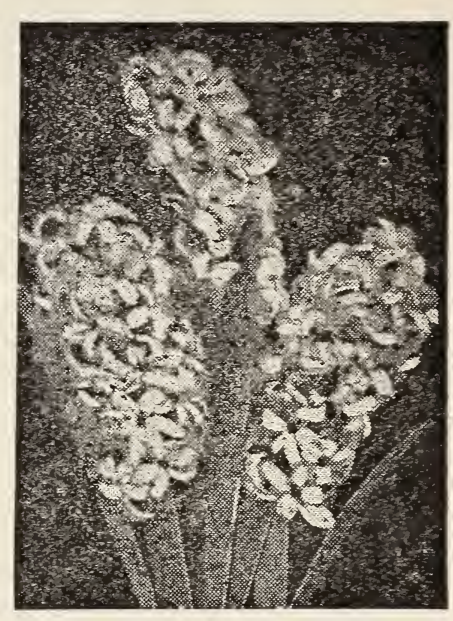

Iyacinths

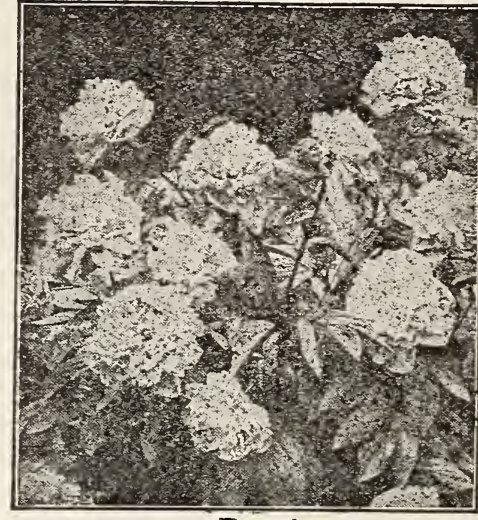

Peonies

\section{Peonies}

Couronne d'Or-White with ring of yellow and crimson splashes. Very valuable variety for dependability and size; a true "crown of gold."

Delicatissima-Lilac rose color; long used in cut flower trade; very dependable and strong; makes fine showing.

Duchess de Nemours-Pure white superb cup-shaped flowers; beautiful in bud state; several days after Festiva Maxima.

Idulis Superba-One of the large, strong, best early pinks; very fragrant.

Felix Crousse-The leading red; late; fine form; fragrant; every garden should have this variety.

Festiva Maxima-Very large; pure white with crimson marks; loose petalage, very early; should be in every garden.

Golden Harvest-Creamy pink; very large and fragrant.

Jeanne d'Arc-Exquisitely scented, large flowers. Lilacpink guards and tufted center, body soft yellow.

Mons. Jules Elie-Glossy lilac pink; enormous flowers; early midseason; a grand peony.

\section{TULIPS}

One of the most popular of early spring flowers; various colors and shades; single and double, early, parrot, Darwin, and cottage garden varieties; April-May; 6-32 inches. 


\section{HARDY PERENNIALS}

Achillea (Boule de Neige)-Perfect white flowers all summer; an improved form of the old popular "Pearl.', 15 in.

Anemone (Japanese Windflower)-Fine white flowers.

Aquilegia (Columbine)-Old favorite spring and early summer flowering plants that succeed in any ordinary garden soil. We have a selection of red and yellow, yellow, white, blue and white, and violet varieties. $1 / 2 \mathrm{ft}$.

Asters (Michaelmas Daisies)-These are among the showiest of our late-flowering hardy plants, giving a wealth of bloom when most other flowers are gone. Blues, violets and white. September-October. $2 \frac{1}{2}-4 \mathrm{ft}$.

Boltonia (False Chamomile)-Among the showiest of our native perennial plants with large, single aster-like flowers; blooms in summer and autumn months; white and pink. 4-7 ft.

Campanula IFedium (Canterbury Bells)-An oldtime favorite; shades of pink. purple and white. June-July. 2-3 ft

Chrysanthemums (Pompon)-These beautiful hardy sorts are indispensable in the hardy bord$\in \mathrm{r}$. Their bright colors give life to the garden when other plants have
been destroyed by frost
We offer many varieties 2-3 ft Coreopsis, Ianceolata (Tick Seed)-One of the most hardy plants. The flowers are a rich golden yellow. rich golden yellow.

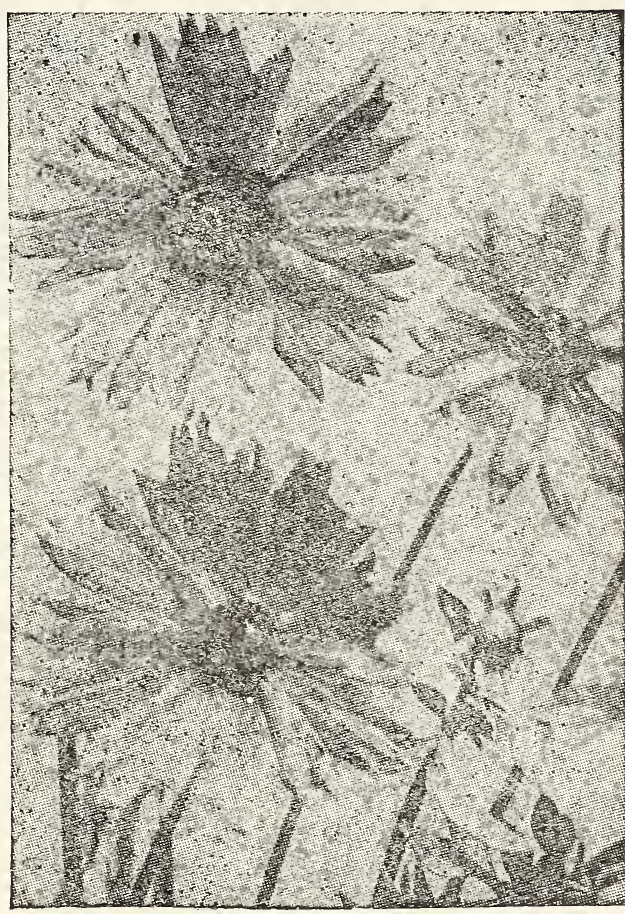

Coreopsis. (Tick Seed) and invaluable for cutting; blooms throughout summer and autumn. 2-3 ft.

Daisy, Shasta (Chrysanthemum) - Large snowy-white flowers 4 inches across; in bloom all summer; a good cut flower varietty.

Delphiniums (Hardy Larkspur)-These are deservedly one of the most popular subjects in the hardy border; turquoiseflat clusters; June-July. $1 \mathrm{I} / 2 \mathrm{ft}$.

Dianthus (Sweet William) - Various colored flowers in large blue flowers; June-frost. 2-3 feet.

Digitalis (Foxglove)-Old-fashioned, dignified and stately during their period of flowering, dominating the whole garden. Bold masses of leaves and flower spikes. White, purple, and rose flowers; June-July; $2-3 \mathrm{ft}$.

Funkia (Plantain Lily, - Is among the easiest plants to cultivate. Their broad, massive foliage makes them attractive subjects for the border even Hollyhocks

when not in bloom; blue, lilac and white; August-October; 10 in.

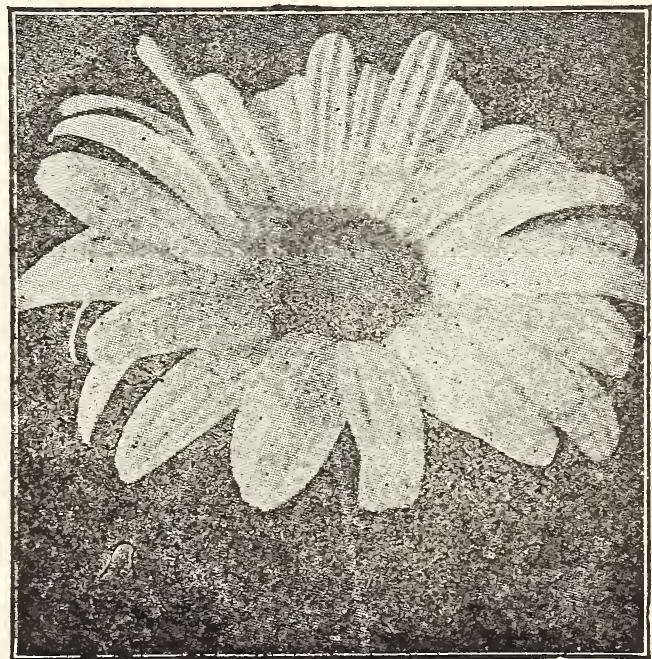

Shasta Daisy 


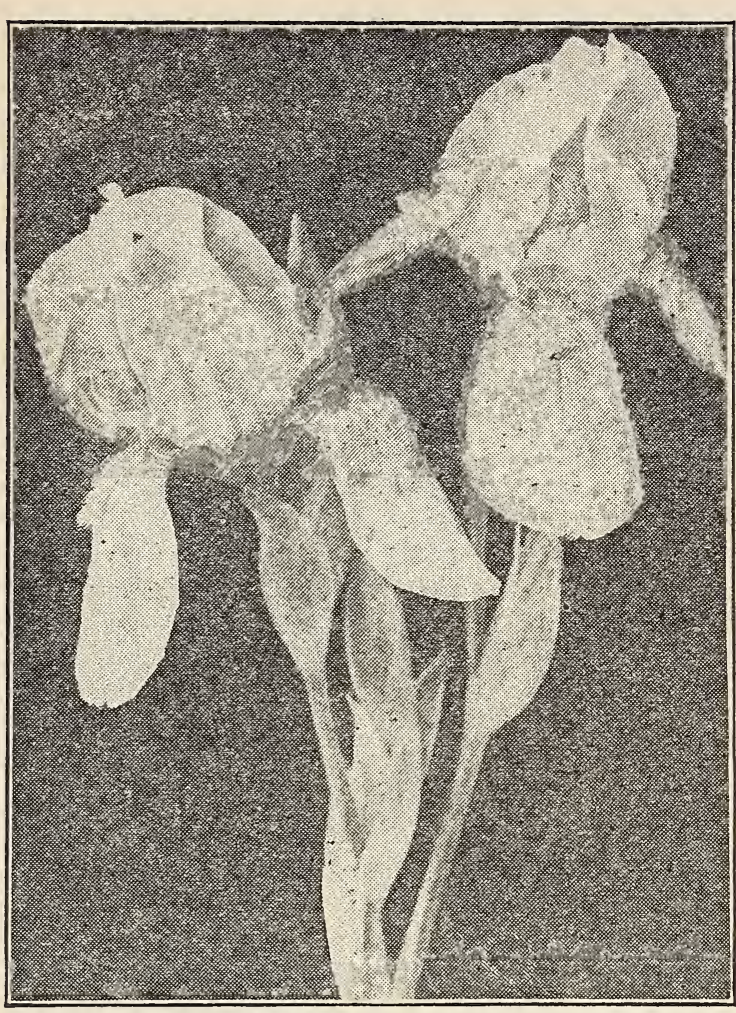

Iiberty Iris

Helianthus (Hardy Sunflowers) - The perennial sunflowers are among the most effective hardy plants for large borders; invaluable for decorative purposes or as cut flowers; September-October; 3-7 ft.

Hibiscus (Mallow)-Desirable border plants with large foliage and large showy flowers of delicate coloring, produced during the entire summer; crimson, pink and white; 4-6 ft.

Iollyhocks-Few hardy plants combine as many good qualities as the Hollyhock. For planting in rows or groups on the lawn, or for interspersing among shrubbery, they are invaluable. The flowers form perfect rosettes of the most lovely shades of yellow crimson, rose pink, orange, white, etc. The Hollyhock requires a rich, deep soil, well drained and will repay in quality and elegance of bloom any extra care. A slight protection in the winter will be beneficial.

\section{IRIS}

Iiberty (Fleur de Lis)-Familiar and well beloved flowers of spring. This group blooms in May with wonderful combinations of coloring; leaves broad. swordlike. We have an assortment of the best sorts.

Japanese (Kaempferl) - Should be planted in a somewhat cool, moist situation. and in rich soil. Its flowers, in late June and July, are quite distinct from those of all the varieties. and will compare favorably with some of the exotic orchids. We have a good assortment of the best varieties.

\section{HARDY PHLOX}

Fardy Phlox-The ease with which they are cultivated. season of blooming, combined with the varied and beautiful color- ing make them particularly valuable for garden planting. In bloom from June till late autumn. Phlox are very effective either as single specimens, in small groups, or large beds on the lawn.

Bridesmaid-Pure white with crimsoncarmine eye.

Champs Flysees-Bright rosy-magenta, very effective.

Elizabeth Campbell-Bright salmonpink with lighter shadings and dark crimson eye.

IMrs. Jenkins-The best all around pure white.

Miss Iingard-Waxy white with lavender eye; longest spike of any Phlox.

IMyosotis (Forget-Me-Not)-Delightful plant, hardly ever out of flower; useful in any shady spot in borders; ulue.

Platycodon_ (Balloon Flower)-Form nest branched bushes of upright habit, continuous succession of white or blue flowers, June-October. $2 \mathrm{ft}$

Rudbeckia (Golden Glow) - Greatly popular; produces masses of double golden-yellow Dahlia-like flowers; JulySeptember. 4-6 ft.

Stokesia (Stokes Aster)-Beautiful native hardy plant; lavender-blue or white; cornflower-like blossoms 4 to iches across; July-October. 18-24 in.

Veronica (Speedwell)-Pretty blue, rose white flowers produced on long spikes; July-September; $1-2 \mathrm{ft}$.

Yucca rilamentosa (Adam's Needle)Finest hardy ornamental foliage and flowering plants; branched spikes of large, fragrant, drooping white flowers; half evergreen; June-July; 4-6 ft.

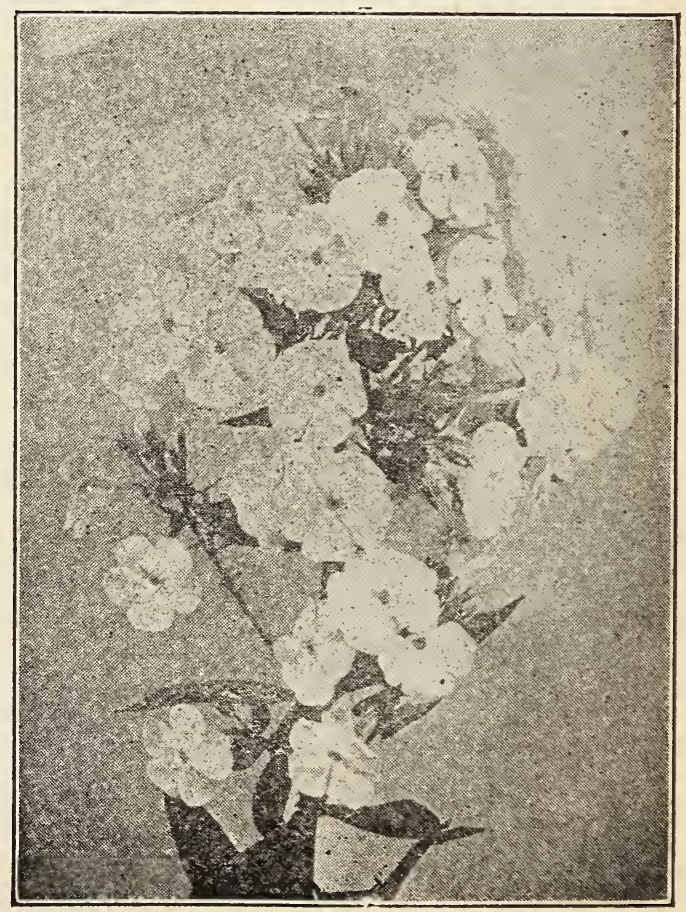

Hardy Phlox 


\section{INFORMATION}

This Catalog contains only varieties adapted to a wide range of country. We have however "Trees and Plants for every Place and every Purpose", so can furnish other varieties of merit if wanted.

For over a Quarter Century, we have been supplying First Class Nursery Goods to the property owners in nearly every State in the Union. Our reliability will be vouched for by Dun or Bradstreet or the Merchants Bank and other Banks in Rochester.

How to Order. Write plainly your Rural Route or Street address, Post Office and State; and express or R. R. Station if different from your Post Office -Use order form.

Shipment-Your goods will be shipped, direct from Nursery, by Parcel Post, Express or fast freight, according to quantity-Shipments are made in March, April and May in the spring and in Ost. or Nov. in fall.

Terms-Cash with order. Remit by Draft or P. O. or Express Money Order. If you want C. O. D. shipment, enclose with order $50 \%(1 / 2)$ of its amount, balance payable on receipt of goods

Nvrcery Insfection Certificate from N. Y. State Agricultural Department accompanies each shipment, showing our goods are free from contagious diseases, San Jose scale or other insects.

\section{PRICES}

For Guaranteed Strictly 1st Class Trees and Plants that will fruit and bloom a year or more ahead of "Cheap, stunted 2nd and 3rd class" goods-and do better ever after. Prices are F. O. B. Rochester. 
Prices are given by Pages of Catalog-for instance to find price of spireas on page 24 of Catalog, locate Page 24 below.

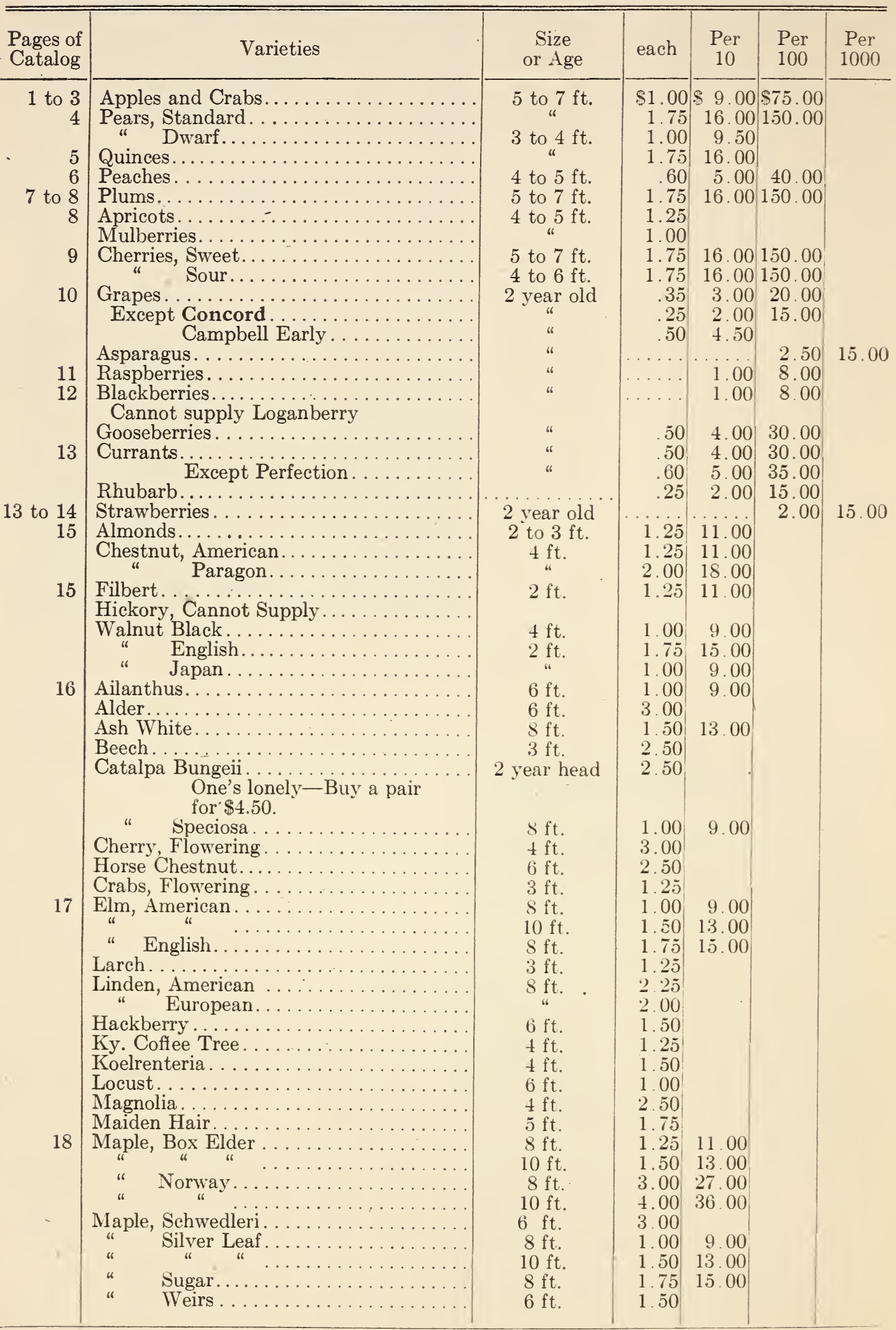




\begin{tabular}{|c|c|c|c|c|c|c|}
\hline $\begin{array}{l}\text { Pages of } \\
\text { Catalog }\end{array}$ & Varieties & $\begin{array}{l}\text { Size } \\
\text { or Age }\end{array}$ & each & $\begin{array}{l}\text { Per } \\
10\end{array}$ & $\begin{array}{l}\text { Per } \\
100\end{array}$ & $\begin{array}{l}\text { Per } \\
1000\end{array}$ \\
\hline 18 & 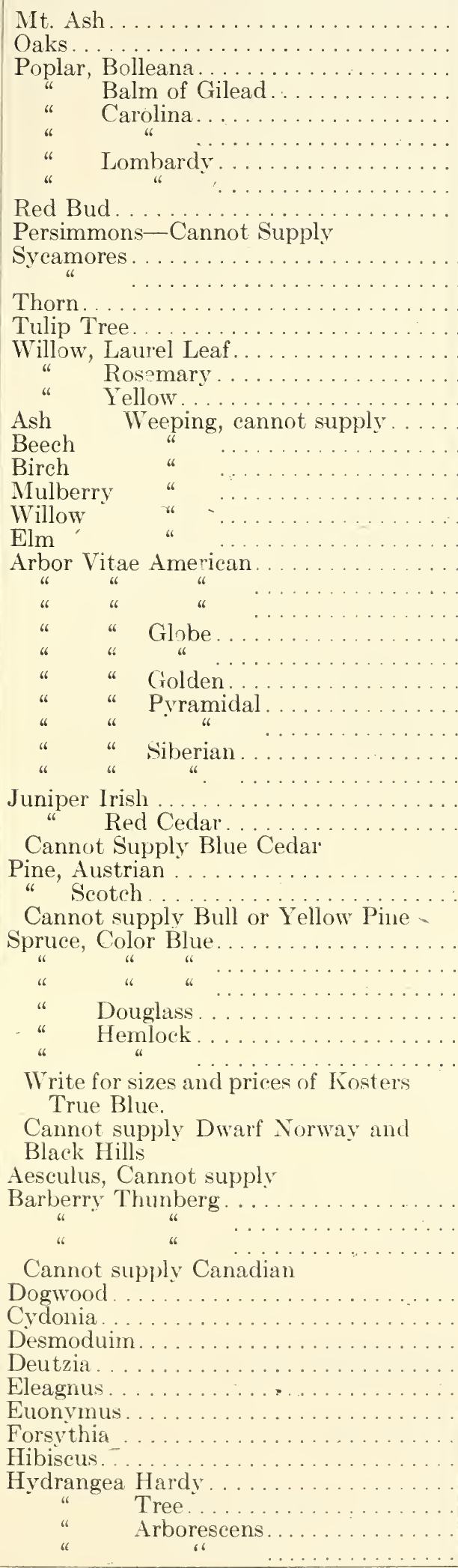 & $\begin{array}{l}8 \mathrm{ft} . \\
5 \mathrm{ft} . \\
8 \mathrm{ft} . \\
8 \mathrm{ft} . \\
8 \mathrm{ft} . \\
10 \mathrm{ft} . \\
8 \mathrm{ft} . \\
10 \mathrm{ft} . \\
4 \mathrm{ft} . \\
8 \mathrm{ft} . \\
10 \mathrm{ft} . \\
3 \mathrm{ft} . \\
6 \mathrm{ft} . \\
6 \mathrm{ft} . \\
6 \mathrm{ft} . \\
6 \mathrm{ft} . \\
4 \mathrm{ft} . \\
5 \mathrm{ft} . \\
5 \mathrm{ft} . \\
6 \mathrm{ft} . \\
5 \mathrm{ft} . \\
12 \mathrm{inch} \\
18 \mathrm{inch} \\
24 \mathrm{inch} \\
12 \mathrm{inch} \\
18 \mathrm{inch} \\
24 \mathrm{inch} \\
24 \mathrm{inch} \\
36 \mathrm{inch} \\
24 \mathrm{inch} \\
36 \mathrm{inch} \\
24 \mathrm{inch} \\
18 \mathrm{inch} \\
24 \mathrm{inch} \\
24 \mathrm{inch} \\
18 \mathrm{inch} \\
24 \mathrm{inch} \\
36 \mathrm{inch} \\
24 \mathrm{inch} \\
18 \mathrm{inch} \\
24 \mathrm{inch}\end{array}$ & $\begin{array}{r}\$ 2.00 \\
2.00 \\
1.00 \\
1.00 \\
.75 \\
1.00 \\
1.00 \\
1.25 \\
1.25 \\
1.25 \\
2.00 \\
1.50 \\
1.50 \\
1.00 \\
3.00 \\
1.25 \\
3.50 \\
2.50 \\
3.00 \\
1.25 \\
3.50 \\
.50 \\
.85 \\
1.25 \\
2.00 \\
3.00 \\
3.50 \\
3.00 \\
4.00 \\
2.50 \\
3.00 \\
1.50 \\
1.50 \\
2.00 \\
2.00 \\
5.00 \\
7.00 \\
10.00 \\
3.00 \\
2.00 \\
2.50\end{array}$ & $\begin{array}{r}\$ 18.00 \\
9.00 \\
9.00 \\
7.00 \\
9.00 \\
9.00 \\
10.00\end{array}$ & $\begin{array}{r}\$ 7.00 \\
16.00\end{array}$ & \\
\hline
\end{tabular}




\begin{tabular}{|c|c|c|c|c|c|c|}
\hline $\begin{array}{l}\text { Pages of } \\
\text { Catalog }\end{array}$ & Varieties & $\begin{array}{l}\text { Size } \\
\text { or age }\end{array}$ & each & $\begin{array}{c}\text { Per } \\
10\end{array}$ & $\begin{array}{l}\text { Per } \\
100\end{array}$ & $\begin{array}{c}\text { Per } \\
1000\end{array}$ \\
\hline $\begin{array}{r}26 \text { to } 27 \\
28 \\
\\
\\
29\end{array}$ & 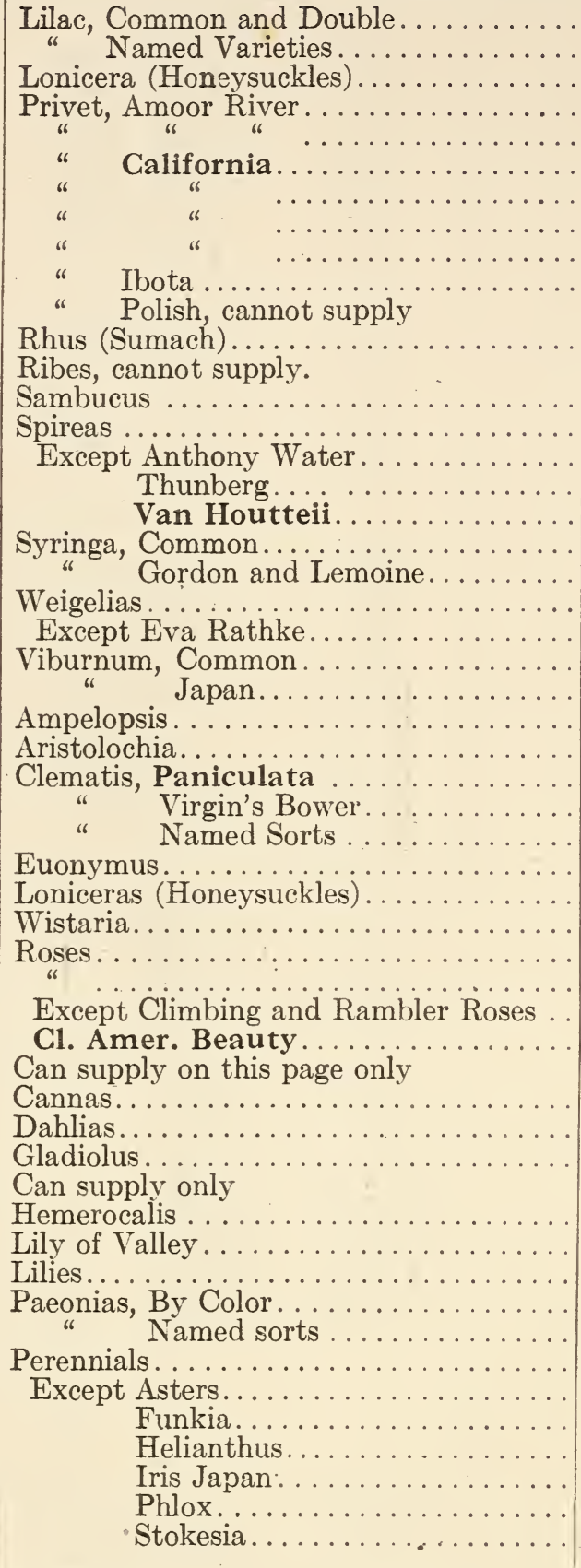 & $\begin{array}{c}2 \text { to } 3 \mathrm{ft} . \\
\text { " } \\
12 \text { inch } \\
18 \text { inch } \\
6 \text { inch } \\
12 \text { inch } \\
18 \text { inch } \\
24 \text { inch } \\
18 \text { inch } \\
2 \text { to } 3 \mathrm{ft} . \\
\text { " } \\
\text { " } \\
18 \text { inch } \\
2 \text { to } 3 \mathrm{ft} . \\
\text { " } \\
2 \text { to } 3 \mathrm{ft} . \\
\text { " } \\
\text { “ } \\
\text { Strong Vines } \\
\text { " } \\
\text { " } \\
\text { " } \\
\text { " } \\
\text { " } \\
\text { Strong Plants } \\
\text { " } \\
\text { " }\end{array}$ & $\begin{array}{r}1.00 \\
.75 \\
.75 \\
.60 \\
.60 \\
.50 \\
.50 \\
.75 \\
.75 \\
1.00 \\
.75 \\
1.00 \\
.50 \\
2.00 \\
.50 \\
.75 \\
1.00 \\
.50 \\
.50 \\
.60 \\
1.00 \\
1.00 \\
.60 \\
1.00 \\
\\
. .2 \\
.25 \\
. .2 \\
.25 \\
.15 \\
.75 \\
.50 \\
.75 \\
.25 \\
.35 \\
.50 \\
.50 \\
.50 \\
.30 \\
.50\end{array}$ & $\begin{array}{l} \\
\\
\\
\\
\\
\\
\\
\\
\\
\\
\\
\\
\\
\\
\\
\\
\\
\\
\\
9.00 \\
9.00 \\
5.00 \\
9.00 \\
1.50 \\
2.00 \\
.75 \\
2.00 \\
1.25 \\
6.00 \\
4.50 \\
6.50 \\
2.00 \\
3.00 \\
4.50 \\
4.50 \\
4.50 \\
2.50 \\
4.50\end{array}$ & $\begin{array}{r}\$ 18.00 \\
25.00 \\
4.00 \\
6.00 \\
8.00 \\
10.00 \\
35.00\end{array}$ & \\
\hline
\end{tabular}

\section{FEDERAL NURSERIES, Inc. ROCHESTER, N. Y.}

Trees and Plants for Every Place and Every Purpose 



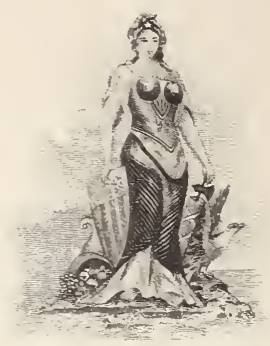

THE NURSERIES WITH EVERYTHING HARDY THAT GROWS IN THE GROUND

\section{Fuderay Murseries}

(INCORPORATED)

Rocuwstwi, NY. lay 12, 1922

Ir. Uharles S. Phillips,

Pocopson, Pa.

Dear Sir:-

You will find the prices of Apples and hulberries in the accompanying price list and we hope you will favor us with your early order for shipment nezt rall or spring.

This will enable us to reserve for you the goods vanted and owing to the stock situation and early reservation shruld be asked for.

We hope, therefore, to receive your order in a short time.

Yours very truly,

FEDERA I IURSEA IES

CGS MIS 


\section{DISTANCES FOR PLANTING.}

Standard Apples .........................40 feet apart each way Standard Pears and Strong Growing Cherries..........20 "6 " " " " " Duke and Morello Cherries...................... "6 "6 "6 "6 "6 Standard Plums, Peaches, Apricots and Nectarines....16 to 18 "6 "6 "6 "6

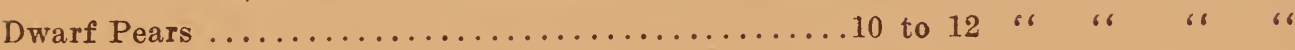

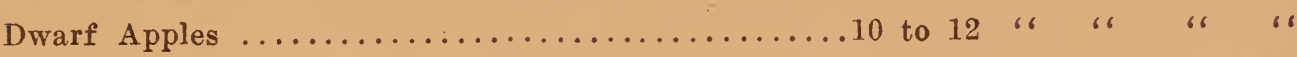

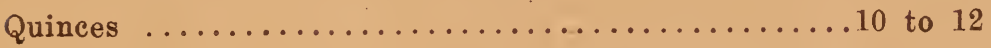
Grapes .................. rows of 10 to 16 feet apart; 7 to 16 feet in rows Currants and Gooseberries ........................... feet apart Raspberries and Blackberries .................... to 4 by 5 to 7 feet Strawberries, for field culture.................... by 3 to $3 \mathrm{r} / 2$ feet Strawberries, for garden culture...................... to 2 feet apart

NUMBER OF TREES ON AN ACRE.

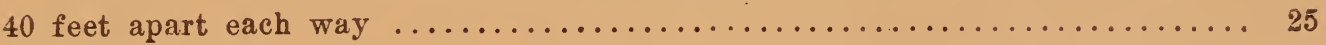

30 " $"$ " $\quad$ "

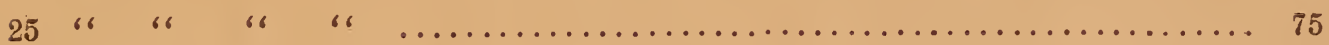

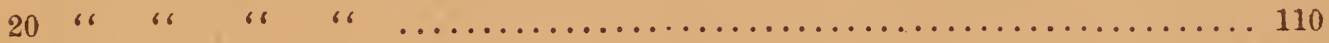

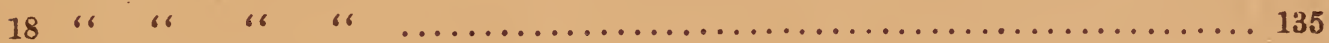

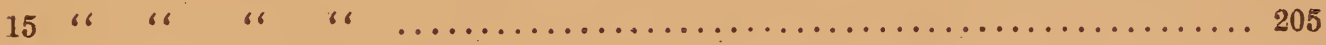

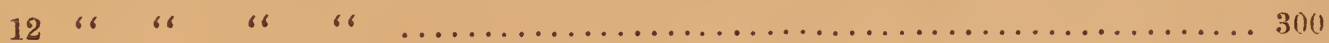

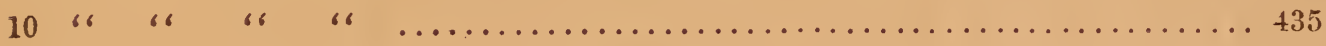

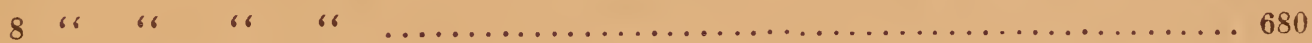

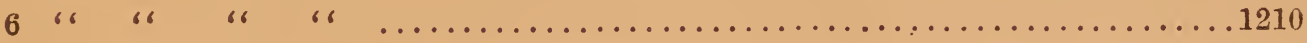

5 ، 6 "

4 " 4 " 6 "

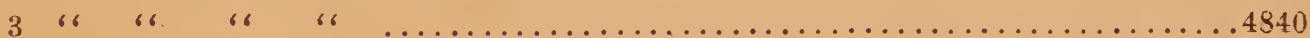

Rule-Multiply the distance in feet between the rows by the distance the plants are apart in the rows, and the product will be the number of square feet, for each give the number of plants or trees to the acre.

plant or hill, which, divided into the number of square feet in an acre $(43,560)$, will 


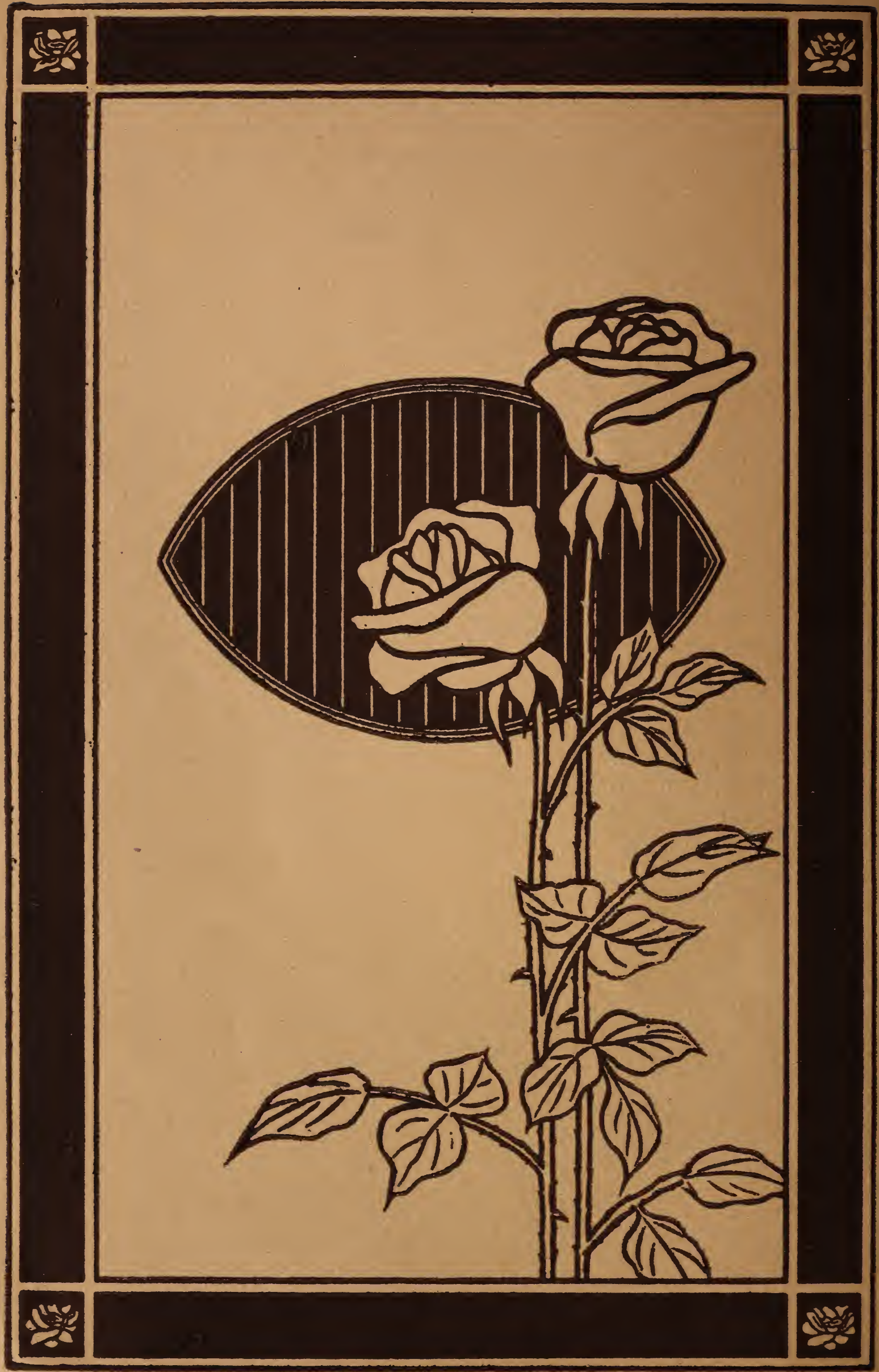

